\title{
SOURCES OF SOCIO-ECONOMIC DEVELOPMENT
}

\author{
Edited by
}

Natalia Potoczek

Volume 13 Issue 4 2017 


\section{Contents}

From the Editor

A Framework for the Evaluation of the Feasibility of Public - Private Partnership in Local Government in Serbia

Sladjana Benkovic, Nemanja Milanovic and Milos Milosavljevic

Measuring the Social Impact of Infrastructure Projects: The Case of Gdańsk International Fair Co.

Anna Zamojska and Joanna Próchniak

Theoretical and Methodical Aspects of Crowdsourcing: Effectiveness and Its Measuring. A Conceptual Paper

Regina Lenart-Gansiniec

Relationships between Trust and Collaborative Culture in The Context of Tacit Knowledge Sharing

Wioleta Kucharska

The Impact of Trust on Entrepreneurship in Poland

Marta Młokosiewicz and Sandra Misiak-Kwit

Developing Entrepreneurial Skills. An Educational and Intercultural

Perspective

Ramona - Diana Leon

List of Reviewers Cooperating with the JEMI in 2017/2018 


\section{From the Editor}

In classical terms, socio-economic development, seen as a process of positive quantitative and qualitative change, is an existing phenomenon of advancement that also gives rise to and develops new ones. If you refer to Schumpeter's concept ${ }^{1}$, economic development takes place in an endless process of innovation, through new production methods and changing consumption patterns. As a consequence of the economic development of the era, living standards are changing and public safety is increasing. The multidimensional character of this process results from numerous, and constantly growing, power sources. Nowadays, the main sources of socio-economic development are perceived to be in the changing relations, and the correlation between individual elements, of the economic system. This approach underlines the importance of structural and qualitative changes observed in new combinations of production assets, production methods, and new goods.

The articles presented in this issue point to various sources of socioeconomic development. According to this latest approach, they include the relationships, attitudes, and competences of various actors. The variety of participation of various entities in economic enterprises significantly stimulates social life and structures them in new dimensions. Individual articles refer to new relations in joint ventures between public and private entities, to the shape of infrastructure projects through social initiatives, to new relationships between legal entities and ordinary people noticeable in the new phenomenon of crowdsourcing, to the importance of trust in socio-economic life, to developing knowledge, and finally to shaping entrepreneurial skills.

The first article covers the issues of public-private partnership supporting local territorial authorities in Serbia. Sladjana Benkovic, Nemanja Milanovic, and Milos Milosavljevic analyze the potential, and level of use, of private equity investments in the public sector. The authors point out a number of benefits resulting from a public-private partnership. The public sector focuses primarily on the infrastructure needed to provide services, while the private sector, taking into account public utilities, focuses simultaneously on the effectiveness of providing services and the financial benefits. The business

1 Schumpeter, J.A. (1983; 1934). The Theory of Economic Development: An Inquiry into Profits, Capital, Credit, Interest, and The Business Cycle. New Brunswick, New Jersey: Transaction Books. Translated from the 1911 original German, Theorie der wirtschaftlichen Entwicklung. 
approach in the provision of public services increases the rationality of the development policy pursued and reduces the risk of increasing public debt. The research results presented by the authors allow one to draw conclusions regarding the significance, potential and needs related to the development of public-private partnerships undertaking business ventures at various levels of local government in Serbia.

In the next article, Joanna Próchniak and Anna Zamoyska use the example of the Gdańsk International Fair in an attempt to examine the social distribution of the costs and benefits of infrastructure projects. The implementation of effective, and carefully selected, infrastructure projects determines economic development, including social development. As the authors note, the majority of infrastructure projects do not bring positive financial results. Hence, in the assessment of projects, economic aspects are adopted that, in addition to financial aspects, include social issues in particular. However, social aspects are difficult to forecast and measure. By deconstructing social benefits and costs into objective and subjective, it makes it possible to compare these two categories and thus evaluate the economic value of a project. Such an approach may be critical in the decision making process about whether to start a given infrastructure project or when assessing a project in its operational phase.

Undoubtedly, crowdsourcing, which is used by various organizations to engage contributors in shaping products and services or creating new initiatives, is an important and growing source of knowledge acquisition. Crowdsourcing is the process by which Internet users participate in implementing, developing or consolidating various socio-economic changes. The article by Regina Lenart-Gansiniec looks at the use of crowdsourcing in the public sector. The author points out that the relatively new phenomenon of crowdsourcing requires research and development, especially in the evaluation of its effectiveness, so her research centers on the measurement of crowdsourcing in public organizations. The proposed action, which presents ways it is possible to assess the level of implementation of the adopted tasks and determine the level of obtained results of crowdsourcing, is an essential voice in the discussion on the sources of socio-economic change and the use of information technology.

Another vital aspect of socio-economic development is the ability to cocreate based on trusted relationships and a readiness to cooperate. Wioleta Kucharska has attempted to investigate the relationship between trust and the culture of cooperation in the context of tacit knowledge sharing. She tested her research hypotheses in quantitative studies conducted among specialists in the construction industry. The primary task was to obtain proof of a correlation between these two factors. According to the results presented 
in the article and the literature on the subject, trust and cooperation between team members are the most critical issues related to the implementation of construction projects. Mutual relations, complexity, the uncertainty of environmental conditions, and time and budget constraints, which are all characteristic of construction projects, increase the need for trust and close cooperation between project participants. The success of a project is an expression of socio-economic development at the level of an organization or organizational network. Therefore, it is reasonable to identify the key variables, and the correlations which occur between them, that determine the success of a project.

The issue of trust in business has been the subject of intense research for many years, especially on the multidimensional nature of this phenomenon. Another article by Marta Młokosiewicz and Sandra Misiak-Kwit concerns the relationship between trust and entrepreneurial activities in Poland. The authors assumed that the formation of trust in the public sphere, and especially in business relations in Poland, had an impact on the intensity of entrepreneurial activities. The research presented in this article covers the period 2002-2016 and presents changes in the potential of social trust, including business confidence. The percentage of people trusting various entities in Poland was assumed as a confidence indicator. As a result of the analysis, the researchers proved that trust in institutions in Poland is quite low in relation to the European average and, what is more, there was a low level of general trust. There was a significant percentage of polar indications, i.e., those dissatisfied with the business environment due to a significant degree of distrust, a lack of credibility, and the reliability of contractors. Due to the universality of the phenomenon, it can be considered that distrust is stable in Polish society and business relationships suppress entrepreneurship.

The research topic of the last article looks at a significant aspect of socio-economic development. The shaping of entrepreneurial attitudes at an academic education level is subject to measurement, as well as whether it is possible to analyze the development of entrepreneurship based on the skills developed by students of economic or business universities. Ramona - Diana Leon's research on developing entrepreneurial skills at European universities was carried out on the basis of an analysis of syllabuses at a selected group of European universities. The author comes to the conclusion that what happens in the education sector has an impact not just on business in general but also at a national level. Based on multinomial logistic regression it can be stated that several entrepreneurial skills allow one to predict whether a given country will achieve high scores in terms of entrepreneurship development or not. Six skills were highlighted in the study, namely: risk taking, communication, problemsolving, teamwork, orientation towards results and time management. These 
searches have both theoretical and practical implications. The research conducted at a theoretical level broadens the literature on entrepreneurial skills, providing information on the skills which academic programs focus on. At a practical level, the research provides a valuable insight into the skills of future entrepreneurs. An additional benefit of the analysis is an indication of the relationship between cultural specificity and the development of entrepreneurial skills, as well as the entrepreneurial level of a given country. The author postulates some extension to the research area, identifying the following three directions: (i) extending the research to a more significant sample of European institutions of higher education; (ii) measuring the entrepreneurial skills of graduates from European business schools; and (iii) analyzing the real entrepreneurial skills developed among graduates.

The Guest Editor of this publication would like to thank all of the authors for presenting their valuable research which constitutes an interesting representation of the contemporary approach to the sources of socio-economic development. At the same time, she would like to thank all the reviewers who have contributed to improving the articles for this quarterly issue of JEMI and to continuing the high standards of the magazine. We hope the articles presented here in this issue will prove to be compelling reading to scholars all over the world and inspire them on to further research in this fascinating area.

\section{Dr. Natalia Potoczek}

Guest Editor, JEMI

Associate Professor, Wyższa Szkoła Biznesu - National Louis University, Poland 


\title{
A Framework for the Evaluation of the Feasibility of Public - Private Partnerships in Local Government in Serbia
}

\section{Sladjana Benkovic ${ }^{1}$, Nemanja Milanovic ${ }^{2}$, Milos Milosavljevic ${ }^{3}$}

\begin{abstract}
The adoption of the New Law for Local Government Financing is currently underway in a Serbian Parliament procedure. The goal of the new law is the creation of clear government regulations which will define the system of financing for local government entities. This will furthermore create an environment of stability and predictability with regard to revenue planning when preparing local government entities' budgets, as well as achieving a vertical balance when distributing revenues amongst various state levels. Additionally, these goals are reflected in the establishment of a system to increase the share of public investment in the total expenses of counties and cities, as well as in the vertical balance with regard to the distribution of revenue and jurisdiction at various state levels. In that sense, it is preferable to understand financial models such as public-private partnerships, which have still not, to an adequate degree, been adopted in Serbia, but one which could potentially contribute to the introduction of additional sources of local government financing. In order to better perceive the current capacities of this model of financing local government in Serbia, a study was conducted during the spring and summer of 2016, taking into account a sample of 150 examinees. The results of the study indicate very low human resource and technical capacities in local government with regard to realizing and comprehending the concept of public-private partnership.
\end{abstract}

Keywords: public-private partnership, local government financing, Serbia.

\footnotetext{
1 Sladjana Benkovic, Ph.D., Full Professor, University of Belgrade, Faculty of Organizational Sciences, Jove llica 154, 11000 Belgrade, Serbia, e-mail: benkovic.sladjana@fon.bg.ac.rs.

2 Nemanja Milanovic, Ph.D. Candidate, University of Belgrade, Faculty of Organizational Sciences, Jove Ilica 154, 11000 Belgrade, Serbia, e-mail: nemanja.milanovic@fon.bg.ac.rs.

3 Milos Milosavljevic, Ph.D., Assistant Professor, University of Belgrade, Faculty of Organizational Sciences, Jove Ilica 154, 11000 Belgrade, Serbia, e-mail: milos.milosavljevic@fon.bg.ac.rs.
} 


\section{INTRODUCTION}

Private capital investment in the public sector is a model of financing public administration by which numerous countries have tried to solve a wide spectrum of financially demanding public needs. This partnership is commonly referred to as a public-private partnership and is executed through a number of different models. The main focus of the public sector is on the infrastructure needed for the service distribution of the public utility, whereas the private sector takes the public utility as a given, and focuses on how to deliver the service as efficiently as possible, and make financial gains (Levitt \& Eriksson, 2016; Rufín \& Rivera-Santos, 2012).

The adoption of the New Law on Local Government Finance is currently underway in a Serbian Parliament procedure. The goal of the new law is the creation of clear government regulations which will define the system of financing for local government entities. This will furthermore create an environment of stability and predictability with regard to revenue planning when preparing local government entities' budgets, as well as achieving a vertical balance when distributing revenues amongst various state levels.

Such a method of financing for a local government represents a specific form of financing that is primarily suitable for the implementation of infrastructure and industrial projects (Espinosa \& Hernandez, 2016; Yang, Long, Cui, Zhu \& Chen, 2017). Many countries have begun to invite private parties to join longterm contractual agreements based on public-private partnerships to improve infrastructure procurement (Grimsey \& Lewis, 2002; Mouraviev \& Kakabadse, 2016). It represents a complex process in which an investor expects payback of the borrowed funds solely from the cash flows generated by an infrastructure project itself. Public-private partnerships are currently used in numerous countries as a tool for infrastructure procurement (Chou \& Pramudawardhani, 2015). This refers to both developed and developing countries (Tserng, Russell, Hsu \& Lin, 2011).

In 2016, the financing of infrastructure through public-private partnerships in local governments showed a tremendous decline worldwide (Word Bank, 2016). When we look at the level at which the public-private partnership appeared, successfully implemented projects through publicprivate partnerships at the national level are almost non-existent. At the local level, at the same time, projects occur in several different fields, through a) the provision of utility services, and b) the construction and reconstruction of public utility facilities.

The first group includes parking services, park maintenance, local public transport, garbage collection, waste transportation and disposal, the provision of market services, cleaning of public areas and the provision of cemetery 
services. The second category includes the construction and reconstruction of the following communal facilities: landfills, water distribution systems, wastewater treatment systems, district heating distribution systems, facilities for the provision of market services, and public garages.

This study aims to examine the main reasons why the concept of publicprivate partnership is not sufficiently employed in Serbian municipalities. The answer to this research question is backed by the results of empirical research conducted in Serbian local governments during the spring and summer of 2016. The results also point out the lack of entrepreneurial initiative in local governments which still strictly rely on budget funds.

The manuscript is organized as follows. Section 2 provides a theoretical background to local government and public-private partnerships, and develops the research hypotheses. Section 3 thoroughly examines the methodology of the study by explaining the main research instrument, sampling procedure and data processing. Section 4 displays the results of the study. Section 5 deals with the discussion of the results. Section 6 is reserved for concluding remarks.

\section{LITERATURE REVIEW}

Local government is "a locally-elected democratic statutory organization below the level of the state, province or region, providing public sector services to the populace within the area of its jurisdiction" (Bailey, 1999, p. 36). It is also referred to as the regulation and management of public affairs under local authorities' responsibility and legal frameworks (Council of Europe, 1985). The bodies of local governments are free to perform their functions in order to achieve the following goals (Vlatkovic, 1994):

- the right of citizens to participate in public affairs at the local level;

- the existence of bodies for decision making and allocating responsibilities for public affairs management;

- to perform public affairs in the interest of the local population within the limits of the law;

- to have sufficient assets to achieve these goals.

Serbian local governments generate around $74 \%$ of their revenues from grants, transfers and taxes, whose rates are under the control of central government. A detailed structure of local governments' revenues is presented below in Table 1 (Ministry of Finance, 2016). Transfer and other tax rates in Serbia are regulated by adopting the annual Law on Transfer Funds Distribution and Participation of Municipalities and City of Belgrade in Income Taxes (The Law on Local Government Finance, 2015). It is noteworthy to point out that Serbian local governments switched from zero-based budgeting to program budgeting in 2015 . 
Table 1. Distribution of Serbian local government revenues 2010-2016 (in millions RSD)

\begin{tabular}{lllllll}
\hline Year & $\begin{array}{l}\text { Total } \\
\text { revenues }\end{array}$ & Taxes & $\begin{array}{l}\text { Transfers and } \\
\text { grants }\end{array}$ & $\begin{array}{l}\text { Other } \\
\text { revenues }\end{array}$ & $\begin{array}{l}\text { Proceeds from } \\
\text { borrowing }\end{array}$ & $\begin{array}{l}\text { Privatization } \\
\text { proceeds }\end{array}$ \\
\hline 2010 & $193.040,50$ & $92.763,70$ & $34.656,20$ & $49.465,40$ & $15.721,90$ & 433,30 \\
2011 & $217.734,30$ & $110.498,20$ & $38.227,00$ & $47.196,90$ & $21.437,80$ & 372,80 \\
2012 & $249.490,00$ & $148.168,50$ & $41.713,20$ & $47.182,10$ & $12.106,40$ & 319,80 \\
2013 & $241.825,80$ & $142.088,10$ & $42.265,30$ & $48.887,60$ & $8.372,10$ & 212,80 \\
2014 & $234.192,00$ & $144.895,80$ & $42.997,40$ & $37.609,80$ & $8.002,40$ & 686,50 \\
2015 & $247.867,10$ & $150.196,90$ & $42.672,70$ & $44.578,30$ & $10.001,50$ & 417,80 \\
2016 & $276.109,20$ & $159.085,80$ & $46.271,00$ & $59.214,30$ & $11.225,50$ & 312,70 \\
\hline
\end{tabular}

Source: Ministry of Finance, Republic of Serbia (2017).

The ever growing need for new investments in traditionally ignored sectors, such as public transport, district heating, gas supply and solid waste management, has forced the local authorities in Serbia to establish publicprivate partnerships and to make room for the implementation of more innovative forms of providing utility services. Lee (2010) states that private sector involvement in financing and providing these services contributes to local governments' economic development. Furthermore, experience has shown that PPPs and their ability to supply private finance improves access, quality of service, operational efficiency, and tariff levels as dimensions of abovementioned sectors' performance (Marin, 2009). Such cooperation between the state and private entities aims to delegate the functions of the supply of water, gas, electricity, heat, utilities and maintenance of quality housing (Lydia \& Olga, 2013), providing numerous benefits to both public and private partner (Filushina, Kolyhaeva, Minaev, Dobrynina \& Merkuleva, 2015). At the same time, the transition from zero-based to program budgeting enables Serbian local governments to strictly monitor key performance indicators of state-owned utility companies and to compare their KPI's with KPI's of companies-partnerships between local government and private sector. Accordingly, the goals and indicators defined in program budgets can be used as a measurement system for the provided services' prices, quality and expenses. Besides the lack of Serbian local governments' agility and interest in partnering with the private sector, the core obstacle for attracting private capital in the utilities sector lies in the fact that the organizational form of public utility companies does not allow a capital increase from private partners (The Law on Public Enterprises, 2014; Vasiljevic, 2012).

Internal and external capacities were examined as critical success factors for the implementation of public private partnerships. Osei-Kyei and Chan 
(2015) find that risk allocation and sharing, strong private consortium, political support, community/public support and transparent procurement are the key critical success factors examined and explored in the extant publications on PPPs. On the other side, Li, Akintoye, Edwards and Hardcastle (2005) find that the most important factors for PPPs are effective search, project feasibility, government assurances, economic conditions and financial factors. To some extent, similar classification is given in Mota and Moreira (2015) who emphasize intrinsic (economic, legal and political environment), and extrinsic (economic viability, trust, risk management and procurement) success factors. Finally, Ng, Wong and Wong (2012) state that the right mixture of adequate technical, financial/economic, social, political, legal, and other factors can assure appropriate implementation of a PPP arrangement. Following the aforementioned, the study hypothesizes that:

Hypothesis 1: Public institutions and organizations have sufficient internal and external capacities for public-private partnerships.

Proponents of PPPs argue that they are an irreplaceable long-term solution due to the fact that the public sector alone cannot solve numerous issues in local governments (Benkovic, Krivokapic \& Milosavljevic, 2015). These partnerships need to be "carefully considered and well-articulated" (World Health Organization, 2015). This skepticism is fueled by PPP flaws such as the reduction of governments' ability to adapt to changing needs (Ross \& Yan, 2015) and high negotiation costs (Välilä, 2005). Following this argumentation, the authors developed a set of inquiries to explore the main reasons and rationale for the implementation of PPPs among Serbian local governments. Jacobson and OK Choi (2008) identified ten success factors that are presented and analyzed: specific plan/vision, commitment, open communication and trust, willingness to compromise/collaborate, respect, community outreach, political support, expert advice and review, risk awareness, and clear roles and responsibilities. However, the main reason for the implementation of PPPs is the lack of financial resources (Benkovic, Makojevic \& Jednak, 2013). Besides financial motives, the study aims to identify other drivers for implementing the concept of public-private partnership. Accordingly, the study hypothesizes that:

Hypothesis 2: Financial drivers are the most important for the implementation of public-private partnerships.

Ahadzi and Bowles (2004) claim that public sector organizations need organizational capabilities and technical capabilities for appropriate proposals on PPPs. The same 
authors indicate that the financial capabilities of the public sector are ranked lowest in influencing the procurement process. The implementation of public private partnerships requires high competencies of employees in local governments. Klijn and Teisman (2010) find that PPPs are not ideal when actors have difficulties in managing PPPs as they tend to "revert to traditional forms-by contracting out and by separating responsibilities". Following the stream of research, this study hypothesizes that:

Hypothesis 3: Public authorities have sufficient knowledge and skills for the implementation of public private partnerships.

\section{RESEARCH METHODS}

\section{Research instrument}

Data was collected using a questionnaire as the main research tool. The questionnaire was developed by the authors, based on a vast literature on critical success factors for the implementation of public private partnerships. Critical success factors are defined as "those few key areas of activity in which favorable results are absolutely necessary" for decision maker to reach their goals (Rockart, 1982, p. 76). Ever since the emergence of public private partnerships, the concept of CSFs has been employed by many researchers aiming to find the best ways for the implementation of public private partnerships (Liu, 2014).

The questionnaire used in the research consists of four parts. The first part addresses the demographic data and includes demographic data on examinees and examined local governments. The second part explored general attitudes, and internal and external capacities for the implementation of public-private partnerships. The third part focused on the examination of the main reasons for the implementation of public-private partnerships in the observed local governments. Finally, the fourth part analyzed the skills and knowledge of civil servants and political appointees related to publicprivate partnership implementation.

\section{Sampling procedure, sample characteristics and data processing}

The study examined the readiness of employees for the implementation of public-private partnerships in order to raise entrepreneurial awareness in the Serbian local governments. At the same time, this implies the strengthening of potential for local governments' financing, improving the quality of services at lower prices and rerouting of local governments' resources to other projects. The study was conducted on 150 examinees in ten Serbian local governments. 
As the total population of the local administration staff dealing with PPPs is unknown (to the best of authors' knowledge there is no global database of specialized clerks and managers), the sampling procedure was based on a "snowball" sampling technique (Biernacki \& Waldorf, 1981). This sampling relies on peer-to-peer recruitment of study participants and the formation of a referral chain (Bodin, et al., 2016). Although it can be a subject of various biases (see Avrachenkov, Neglia \& Tuholukova, 2016), the referral chain was actively controlled - particularly its initiation, progress and termination. Using the coded questionnaires, the number of referrals was controlled to limit the clustering within local administration with regards to their size. The distribution of examinees per the size of local administration is displayed in the Table 2.

Table 2. Distribution of examinees per local administration size

\begin{tabular}{ll}
\hline Size of local administration & Frequency \\
\hline Small $<10$ & 1 \\
Medium sized 11-50 & 44 \\
Large $51-250$ & 63 \\
Very large $>250$ & 38 \\
Total & 146 \\
Missing & 4 \\
Total & 150 \\
\hline
\end{tabular}

Data was captured by trained assistants and was entered and analyzed in the Statistical Package for Social Scientists program (SPSS) version 17.0. Quantitative data 27 was analyzed with demographic statistics: percentages, means and standard deviation. Interdependence of determinants (independent variables) and the attractiveness of public-private partnerships (dependent variable) were determined by correlation (Pearson moments two tailed correlation coefficient analysis) and multiple regression.

\section{ANALYSIS/STUDY/RESULTS}

Having analyzed these data, we discovered differences in internal capacities for the implementation of public-private partnerships, external capacities for the implementation of public-private partnerships in the Republic of Serbia, as well as rationalization for the implementation of public-private partnerships and disposable knowledge and skills for the implementation of public-private partnerships in the Republic of Serbia. 
Internal and external capacities for the implementation of publicprivate partnerships

Based on the previously elaborated body of knowledge, this study examined internal and external capacities for the implementation of public-private partnerships. Both of them were examined using a Likert-type scale (ranks 1-5). Internal capacities were examined through the following:

1) The suitability of PPP arrangements for local government.

2) Attitude of civil servants towards PPPs.

3) Attitude of political appointees (local government executives) towards PPPs.

4) General level of qualifications of employees.

5) General possibilities for the implementation of PPPs.

External capacities of local governments for the implementation of publicprivate partnerships were measured through the following inquires:

1) Favorability of legal procedures for the implementation of PPPs.

2) The amount of risk involved in PPP arrangements.

3) Unfavorable corruptive environment.

4) Inefficiency of central bodies.

5) Benevolence of political appointees towards the PPP model.

The results for internal and external capacities of local governments for the implementation of public-private partnerships are given in Table 3.

Table 3. Internal and external capacities for the implementation of PPPs

\begin{tabular}{lll}
\hline Internal capacities & Mean & Std. Deviation \\
\hline Suitability of PPP for local government & 3.50 & .923 \\
Attitude of civil servants & 2.21 & .719 \\
Attitude of political appointees & 2.60 & .861 \\
Employee qualifications & 2.43 & .812 \\
Possibilities for the implementation of PPPs & 2.86 & .858 \\
\hline External capacities & Mean & Std. Deviation \\
\hline Unfavorable legal procedures & 3.12 & .534 \\
High risk(s) & 3.27 & .510 \\
High level of corruption & 3.19 & .689 \\
Inefficient central bodies (Commission for PPP) & 3.56 & .744 \\
Incompatible political appointees & 3.47 & .830 \\
\hline
\end{tabular}

The results indicate that examinees found public-private partnerships to be an appropriate model for financing local government services. However, the general qualifications and expertise of employees is the main barrier. From the external point of view, the main limitations are systematic and driven from the inappropriate work of the central body for public-private 
partnerships which approves all projects of this kind. Considering the above mentioned findings, it can be stated that the first hypothesis is rejected.

\section{Rationale for public-private partnerships}

As the main rationales for implementation encompass both instrumental and normative aims (Brinkerhoff \& Brinkerhoff, 2011), the study examined 6 items of possible reasons for the implementation of public private partnerships. The results of descriptive statistics are presented in Table 4.

Table 4. The descriptive statistics for the main reasons for the implementation of PPPs

\begin{tabular}{lll}
\hline & Mean & Std. Deviation \\
\hline The lack of financial resources & 3.73 & .859 \\
The lack of service needed in the municipality & 3.19 & .808 \\
The urgency of service & 3.16 & .757 \\
High institutional support & 2.57 & .909 \\
The attractiveness of the project to potential investors & 3.42 & .806 \\
Private partner would cope with the risk better & 3.26 & .861 \\
\hline
\end{tabular}

As displayed in the table, the main reason for the implementation of public-private partnerships is the lack of financial resources (3.73), followed by the attractiveness of possible projects (3.42). However, examinees stated that institutional support needs to be improved if public-private partnerships are to be an important model for financing local projects, by which the second hypothesis is confirmed.

Table 5. Correlation matrix for particular reasons for the implementation of PPPs and the attractiveness of the model

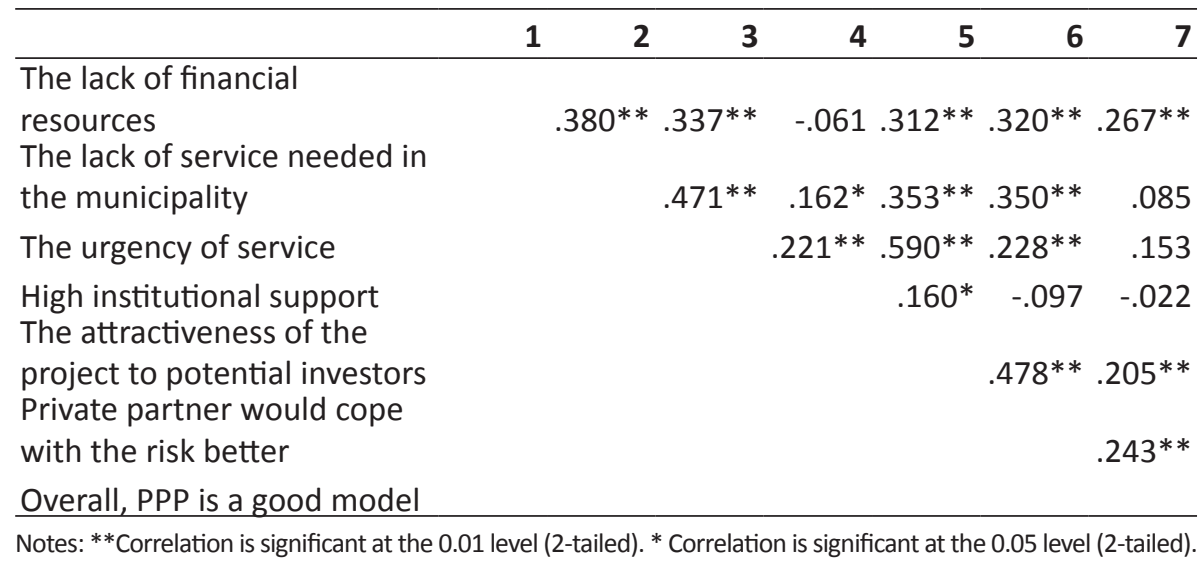


For the purpose of addressing hypothesis 2, a correlation and regression analysis was conducted. As shown in Table 5, significant correlation (with the attractiveness of public-private partnerships) was found between three particular reasons - a lack of financial resources, the attractiveness of projects offered to investors, and a private partner coping with the risks better.

Since the study found a strong positive correlation between rationales for the implementation of PPP variables and the attractiveness of publicprivate partnerships, the next step was the examination of the influence and intensity of variables seen as independent to the attractiveness of PPP (dependent variable). Results of the multiple regression analysis indicated that the research model predicted only $11.1 \%(R 2=.111)$ of the variability of the attractiveness of public-private partnerships, which is shown in Table 6 . As Durbin-Watson was $d=1.700$ (between two critical values $1.5<d<2.5$ ), it could be assumed that there is no first order linear autocorrelation in the multiple linear regression data. Collinearity was further examined with the variance inflation factor, and none of the variables had high VIF leading to the conclusion that the model did not express any multi-collinearity.

High significance of the F-test $(p<.01)$, indicates the existence of linear interdependence. Thus, the study results indicate that there was a linear relationship between the variables in the model. Beta expresses relative importance of each independent variable in standardized terms. Only one determinant was found to be a significant predictor of the attractiveness of public-private partnerships. Accordingly, the study results clearly indicate that the attractiveness depends on the fiscal considerations.

The results indicate that local governments lack employees with the appropriate knowledge in risk analysis (2.74), cost effectiveness (2.77) and value-for money studies (2.83). It is important to emphasize that the skills needed for traditional methods of procurement are highly developed, which could easily lead PPPs to traditional forms of service procurement. According to the described results, the third hypothesis is rejected. 
Table 6. Regression analysis for the attractiveness of PPP model

\begin{tabular}{|c|c|c|c|c|c|c|c|}
\hline \multirow[b]{2}{*}{ Model } & \multicolumn{2}{|c|}{$\begin{array}{l}\text { Unstandardized } \\
\text { Coefficients }\end{array}$} & \multirow{2}{*}{$\begin{array}{c}\text { Standardized } \\
\text { Coefficients } \\
\text { Beta } \\
\end{array}$} & \multirow[b]{2}{*}{ 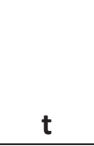 } & \multirow[b]{2}{*}{ Sig. } & \multicolumn{2}{|c|}{$\begin{array}{c}\text { Collinearity } \\
\text { Statistics }\end{array}$} \\
\hline & B & Std. Error & & & & Tolerance & VIF \\
\hline (Constant) & 1.998 & .453 & & 4.415 & .000 & & \\
\hline $\begin{array}{l}\text { The lack of financial } \\
\text { resources }\end{array}$ & .227 & .094 & .213 & 2.418 & .007 & .766 & 1.305 \\
\hline $\begin{array}{l}\text { The lack of service } \\
\text { needed in the } \\
\text { municipality }\end{array}$ & -.112 & .107 & -.099 & -1.054 & .294 & .669 & 1.494 \\
\hline $\begin{array}{l}\text { The urgency of } \\
\text { service }\end{array}$ & .078 & .127 & .064 & .613 & .541 & .541 & 1.849 \\
\hline $\begin{array}{l}\text { High institutional } \\
\text { support }\end{array}$ & -.019 & .085 & -.019 & -.224 & .823 & .871 & 1.148 \\
\hline $\begin{array}{l}\text { The attractiveness } \\
\text { of the project to } \\
\text { potential investors }\end{array}$ & .060 & .122 & .052 & .490 & .625 & .516 & 1.938 \\
\hline $\begin{array}{l}\text { Private partner } \\
\text { would cope with } \\
\text { the risk better }\end{array}$ & .182 & .101 & .170 & 1.799 & .074 & .666 & 1.501 \\
\hline
\end{tabular}

Note: R2=.111; Adj R2=.076, F=3.130 (Sig=.006); Durbin-Watson=1.700.

\section{Knowledge and skills for public-private partnerships}

For the purpose of addressing Hypothesis 3, this study examined the main competencies of local government employees. The results are displayed in Table 7.

Table 7. Knowledge and skills of local government employees required for the successful implementation of PPPs

\begin{tabular}{lll}
\hline & Mean & Std. Deviation \\
\hline Public procurements & 3.51 & .624 \\
Legal procedures & 3.34 & .580 \\
Value for money analysis & 2.83 & .752 \\
Risk analysis & 2.74 & .779 \\
Cost benefit analysis & 2.77 & .800 \\
Financial management & 2.84 & .803 \\
Project control & 2.97 & .675 \\
Contracting and negotiating & 3.01 & .642 \\
\hline
\end{tabular}




\section{DISCUSSION}

The aim of the study was to provide an answer as to why the concept of publicprivate partnership is not sufficiently employed in Serbian municipalities. Accordingly, we examined internal and internal factors that drive PPPs, the main reasons for the implementation and the knowledge and skills of public administration in handling PPPs. In a nutshell, public private partnerships are a suitable model for financial local infrastructure and delivery of public services, but local administration lacks expertise for the appropriate implementation of particular projects. Also, the most important determinants for any consideration of application of public-private partnerships are fiscal constraints and lack of funds. Finally, the most important skills that local administrations need are related to the legal issues (public procurements, legal procedures and contracting).

The main contribution of the paper is reflected in understanding the current environment for strengthening entrepreneurship in Serbian local governments, which implies improving the quality of provided services at lower prices and the rerouting of local governments' resources to projects which are out of the private sector's interest. However, local administrations need to improve their capacities (knowledge and skills) for the implementation of complex projects. Capacity building initiatives have already proven to be a solid tool for improvement in the public-private partnership area (Aijaz, 2010). Fewer financial, human, land and property resources under the control of local governments facilitate private initiatives and local economic development.

An additional contribution of this paper is the empirical proof that financial constraints are a fundamental driver for public-private partnerships. It should, however, be noted that resources saved by a government that does not finance the upfront investment are offset by giving up future revenue flows to the concessionaire (Engel, Fischer \& Galetovic, 2013). More than merely a financial issue, public-private partnerships carry substantial organization, strategy, management and policy implications (Roehrich, Lewis \& George, 2014).

\section{CONCLUSION}

In this study, we aimed to stress the significant potential of public-private partnerships for the financing and economic development of Serbian local governments. It is evident that local governments have both internal and external capacities needed for the successful implementation of publicprivate partnerships, but their employees' still lack the sufficient knowledge and skills necessary for this process. Therefore, intensive educational 
programs and training for the improvement of employees' competencies, skills and knowledge are suggested as one of the priorities for efficient local government development.

Besides permanent education and training of employees, significant effort must be put into communication and relationship management with citizens and private entities. Public and private sectors have to be understood as cooperative, so therefore collaborations must be considered when they are qualitatively different from both private and public activities, and superior to each on its own. The public-private partnership concept represents an established systematic approach of many governments and local self-governments around the world when it comes to financing public infrastructure. Over the past few years, municipalities in Serbia have made the first tentative steps towards the introduction of public-private partnerships, mainly in the utilities sector. The growing need for new investments in traditionally neglected sectors, such as public transport, district heating, gas supply and solid waste management, has forced the municipal authorities in Serbia to, little by little, establish public-private partnerships and open the door to more innovative forms of providing utility services.

The local authorities in Serbia are still in the early stages of the process of establishing the political, legal and administrative framework that would facilitate the development of public-private partnerships. However, improving the quality of provided services at lower prices, the rerouting of local governments' resources to projects which are out of the private sector's interest, and the permanent education and training of employees could considerably facilitate entrepreneurial orientation and the implementation of public-private partnerships in Serbian local governments.

\section{References}

Ahadzi, M., \& Bowles, G. (2004). Public-private partnerships and contract negotiations: An empirical study. Construction Management and economics, 22(9), 967-978.

Aijaz, R. (2010). Capacity building of municipal functionaries for good governance in Uttarakhand, India. Habitat International, 34(4), 386-391.

Avrachenkov, K., Neglia, G., \& Tuholukova, A. (2016) Subsampling for chainreferral methods. In S. Wittevrongel \& T. Phung-Duc (Eds.), Analytical and Stochastic Modelling Techniques and Applications (pp. 17-31). ASMTA 2016. Lecture Notes in Computer Science, 9845. Cham: Springer.

Bailey, S.J. (1999). Local Government Economics: Principles and Practice. Basingstoke: Palgrave Macmillan.

Benkovic, S., Krivokapic, J., \& Milosavljevic, M. (2015). Application of the public-private partnership organizational structure in the improvement 
of business operations of public sector enterprises in Serbia. Lex Localis, 13(3), 397.

Benkovic, S., Makojevic, N., \& Jednak, S. (2013). Possibilities for development of the electric power industry of Serbia through private source financing of small hydropower plants. Renewable Energy, 50, 1053-1059.

Biernacki, P., \& Waldorf, D. (1981). Snowball sampling: Problems and techniques of chain referral sampling. Sociological Methods \& Research, 10(2), 141-163.

Bodin, T., Johansson, G., Hemmingsson, T., Nylén, C., Kjellberg, K., Buström, B., \& Östergren, P.-O. (2016). S09-2 respondent-driven sampling in sampling hard-to-reach precarious workers. Occupational and Environmental Medicine, 73(Suppl 1), A109.1-A109.

Brinkerhoff, D.W., \& Brinkerhoff, J.M. (2011). Public-private partnerships: Perspectives on purposes, publicness, and good governance. Public Administration and Development, 31, 2-14.

Chou, J. S., \& Pramudawardhani, D. (2015). Cross-country comparisons of key drivers, critical success factors and risk allocation for public-private partnership projects. International Journal of Project Management, 33(5), 1136-1150.

Council of Europe. (1985). European Charter of Local Self-Government. European Treaty Series, 122.

Engel, E., Fischer, R., \& Galetovic, A. (2013). The basic public finance of publicprivate partnerships. Journal of the European Economic Association, 11(1), 83-111.

Espinosa, A., \& Hernandez, T. (2016). A comparison of public and private partnership models for urban commercial revitalization in Canada and Spain. The Canadian Geographer/Le Géographe Canadien, 60(1), 107-122.

Filushina, K.E., Kolyhaeva, J.A., Minaev, N.N., Dobrynina, O.I., \& Merkuleva, J.A. (2015). Regional models on managing the public-private partnership projects in housing and communal complex. Mediterranean Journal of Social Sciences, 6(3S5), 55.

Grimsey, D., \& Lewis, M.K. (2002). Evaluating the risks of public private partnerships for infrastructure projects. International Journal of Project Management, 20(2), 107-118

Jacobson, C., \& Ok Choi, S. (2008). Success factors: Public works and public-private partnerships. International Journal of Public Sector Management, 21(6), 637-657

Klijn, E. H., \& Teisman, G. R. (2003). Institutional and strategic barriers to public-private partnership: An analysis of Dutch cases. Public Money and Management, 23(3), 137-146.

Lee, S. (2010). Development of public private partnership (PPP) projects in the Chinese water sector. Water Resources Management, 24(9), 1925-1945.

Levitt, R.E., \& Eriksson, K. (2016). Developing a governance model for PPP infrastructure service delivery based on lessons from Eastern Australia. Journal of Organization Design, 5(1), 7. 
Li, B., Akintoye, A., Edwards, P.J., \& Hardcastle, C. (2005). Critical success factors for PPP/PFI projects in the UK construction industry. Construction Management and Economics, 23(5), 459-471.

Liu, J., Love, P.E., Smith, J., Regan, M., \& Davis, P.R. (2014). Life cycle critical success factors for public-private partnership infrastructure projects. Journal of Management in Engineering, 31(5), 1-7.

Lydia, O., \& Olga, Z. (2013). The potential of public-private partnership for solving housing and communal services. Analytic and Informative Journal, 126(6), 120-124.

Marin, P. (2009). Public-Private Partnerships for Urban Water Utilities: A Review of Experiences in Developing Countries. Washington DC: World Bank Publications.

Ministry of Finance, Republic of Serbia. (2017). Public Finance Bulletin No. 152. Retrieved from http://www.mfin.gov.rs/UserFiles/File/bilten\%20 javne\%20finansije/2017/ Bilten\%20152\%20ENG\%202007.pdf

Mouraviev, N., \& Kakabadse, N.K. (2016). Conceptualising public-private partnerships: A critical appraisal of approaches to meanings and forms. Society and Business Review, 11(2), 155-173.

Mota, J., \& Moreira, A.C. (2015).The importance of non-financial determinants on public-private partnerships in Europe. International Journal of Project Management, 33(7), 1563-1575.

Ng, S.T., Wong, Y.M., \& Wong, J.M. (2012). Factors influencing the success of PPP at feasibility stage-A tripartite comparison study in Hong Kong. Habitat International, 36(4), 423-432.

Osei-Kyei, R., \& Chan, A.P. (2015). Review of studies on the critical success factors for Public-Private Partnership (PPP) projects from 1990 to 2013. International Journal of Project Management, 33(6), 1335-1346.

Rockart, J.F. (1982). The Changing Role of the Information Systems Executive: A Critical Success Factors Perspective. Boston: Massachusetts Institute of Technology.

Roehrich, J.K., Lewis, M.A., \& George, G. (2014). Are public-private partnerships a healthy option? A systematic literature review. Social Science \& Medicine, 113, 110-119.

Ross, T.W., \& Yan, J. (2015). Comparing public-private partnerships and traditional public procurement: Efficiency vs. flexibility. Journal of Comparative Policy Analysis: Research and Practice, 17(5), 448-466.

Rufín, C., \& Rivera-Santos, M. (2012). Between commonweal and competition understanding the governance of public-private partnerships. Journal of Management, 38(5), 1634-1654.

The Law on Local Government Finance. (2015). Official Gazette of RS, No. 62/2006, 47/2011, 93/2012, 99/2013, 125/2014, and 95/2015 (Article 37).

The Law on Public Enterprises. (2014). Official Gazette of RS, No. 119/2012, 116/2013 and 44/2014.

Tserng, H.P., Russell, J.S., Hsu, C.W., \& Lin, C. (2011). Analyzing the role of national PPP units in promoting PPPs: Using new institutional 
economics and a case study. Journal of Construction Engineering and Management, 138(2), 242-249.

Välilä, T. (2005). How expensive are cost savings? On the economics of publicprivate partnerships. European Investment Bank Papers, 10(1), 94-119.

Vasiljević, D. (2012). Lokalni Ekonomski Razvoj - Zašto Su Jedne Opštine Dobitnici, A Druge Gubitnici Tranzicije. Beograd: PALGO Centar.

Vlatković, M. (1994). Lokalna Samouprava u Srbiji - Prilog Kritici Uređivanja i Ostvarivanja. Beograd: Stalna Konferencija Gradova i Opština.

World Bank. (2016). 2016 Private Participation in Infrastructure (PPI)-Annual Update. Retrieved from https://ppi.worldbank.org/ /media/GIAWB/ PPI/Documents/Global-Notes/2016-PPI-Update.pdf

World Health Organization. (2015). Public-Private Partnerships for Health. Retrieved from www.who.int

Yang, T., Long, R., Cui, X., Zhu, D., \& Chen, H. (2017). Application of the public-private partnership model to urban sewage treatment. Journal of Cleaner Production, 142, 1065-1074.

\begin{abstract}
Polish)
Przyjęcie nowej ustawy o finansowaniu samorzqdów lokalnych jest obecnie w toku procedury parlamentu serbskiego. Celem nowej ustawy jest stworzenie przejrzystych regulacji rzq̨dowych, które określq system finansowania dla jednostek samorzqdu terytorialnego, co dodatkowo stworzy warunki stabilności i przewidywalności w zakresie planowania dochodów przy przygotowywaniu budżetów jednostek samorzqdu terytorialnego, a także jako osiqgnięcie równowagi pionowej przy dystrybucji dochodów między różnymi poziomami państwowymi. Ponadto, cele te znajdujq odzwierciedlenie $w$ ustanowieniu systemowego zwiększenia udziału inwestycji publicznych w całkowitych wydatkach powiatów i miast, a także w równowadze pionowej w zakresie podziału dochodów i jurysdykcji na różnych poziomach państwowych. $W$ tym sensie lepiej jest zrozumieć modele finansowe, takie jak partnerstwa publiczno-prywatne, które jeszcze nie zostały w wystarczajqcym stopniu przyjęte w Serbii, ale które moga potencjalnie przyczynić się do znalezienia dodatkowych źródeł finansowania przez samorzqdy. Aby lepiej dostrzec obecne możliwości tego modelu finansowania samorzqdu lokalnego w Serbii, przeprowadzono badanie wiosna i latem 2016 r., Biorqc pod uwagę próbę 150 osób, wyniki badania wskazujq na bardzo niskie zasoby ludzkie i możliwości techniczne samorzqdu lokalnego w zakresie znajomości i zrozumienia koncepcji partnerstwa publiczno-prywatnego.
\end{abstract}

Słowa kluczowe: partnerstwo publiczno-prywatne, finansowanie samorzqdów terytorialnych, Serbia. 


\section{Biographical notes}

Slađana Benković - Ph.D., has been a full professor at the Faculty of Organizational Sciences in Belgrade since 2014 and has participated in numerous projects. During 2007/2009 she spent a period of time at the George Washington University, Washington D.C. as a research fellow. She is the President of the Management Board of the "Endowment of Milivoje Jovanović and Luka Ćelović", as well as a member of the Management Board of the "Endowment of Đoko Vlajković. . Her teaching and research fields are financial management with a research focus on project finance, modalities of financing the development projects of companies, technical evaluation of investment profitability and determination of corporate capital structure.

Nemanja Milanović - M.Sc., is currently employed as a teaching assistant at the University of Belgrade, Faculty of Organizational Sciences, Department of Financial Management and Accounting. His main fields of research interests are financial management, management accounting and startup funding models. He gained international professional experience through a number of international study and professional exchanges and research projects. He is a member of the European Finance Association and the Youth Committee of the National Petroleum Committee of Serbia - World Petroleum Council.

Miloš Milosavljević - Ph.D., is an assistant professor at the University of Belgrade, Faculty of Organizational Sciences. He teaches Financial Management and Management Accounting and has participated in numerous consulting projects in the field of financial management and controlling. He has authored or coauthored more than 60 articles and conference papers, text books and international monographs. 



\title{
Measuring the Social Impact of Infrastructure Projects: the Case of Gdańsk International Fair Co.
}

\section{Anna Zamojska and Joanna Próchniak ${ }^{2}$}

\begin{abstract}
Efficient infrastructure is a prerequisite of, and critical to, development. Only some projects generate a positive rate of return, but all of them should generate positive non-economic impacts and contribute social gains. Social impact is considered as a consequence or effect of decisions or interventions which lead to development. It can also be considered as a social consequence of development. The main problem of social costs and benefits is that the impact is difficult to predict and quantify and can be taken into account differently by authorities, decision makers and project developers. The main purpose of the paper is to identify and demonstrate a concept of the social impact of infrastructure projects. The principal methods used are a review of existing social science literature and surveys based on focus group interviews, devoted stakeholders of infrastructure projects, and their involvement at different stages of the project. The expected result is a set of outputs and outcomes which demonstrates social impacts (costs and benefits) related to stakeholders' groups of the analyzed project. Keywords: infrastructure project, social impact, cost and benefit analysis.
\end{abstract}

\section{INTRODUCTION}

Efficient infrastructure is a prerequisite and critical in the support of development. Only some projects generate positive rates of return, but all should generate positive non-economic impacts and provide social gains. Due to concerns regarding social economy phenomena and social outcomes of infrastructure, researchers have been interested in analyzing the social distribution of the costs and benefits of infrastructure projects. Social impact is considered as a consequence or effect of decisions or intervention

1 Anna Zamojska, Associate Professor, University of Gdańsk, Department of Econometrics, 101 Armii Krajowej Str., 81824 Sopot, Poland, e-mail: anna.zamojska@ug.edu.pl

2 Joanna Próchniak, Assistant Professor, University of Gdańsk, Department of Business Economics, 101 Armii Krajowej Str., 81-824 Sopot, Poland, e-mail: joanna.prochniak@ug.edu.pl

Received 12 May 2017; Revised 18 October 2017; Accepted 9 November 2017. 
undertaken which lead to development. It can also be considered as a social consequence of development or the issues that directly or indirectly affect people. The greatest problem of social costs and benefits is that the impact is difficult to predict and quantify and can be taken into account differently by authorities, decision makers and project developers.

Stakeholder theory, which came into being in the 1980s, states that the raison d'être of the company is to act as a vehicle for furthering the interests of its stakeholders (Freeman, Harrison, Wicks, Parmar \& de Colle, 2010). In theory, organizations ought to treat all stakeholders equally (McElroy \& Mills, 2007; Phillips, 2003), in accordance with the principle that "no single set of interests prevail over all others" (Mainardes, Alves \& Raposo, 2012, p. 1863). However, in practice, they may not be able to meet the expectations of all stakeholders (Hartmann \& Hietbrink, 2013). It follows that managements may have to prioritize stakeholders, thereby paying greater attention to the interests and expectations of certain groups (often to the detriment of others). This implies that they need to decide which stakeholders to engage with and to what extent (which is all the more relevant in view of the financial constraints faced by some organizations).

The main purpose of this paper is to identify and demonstrate a concept of the social impact of infrastructure projects. The principal methods to be used are reviews of the existing social science literature and surveys based on stakeholders groups of infrastructure projects. The expected result is a set of outputs and outcomes which demonstrates social impacts (costs and benefits) related to stakeholders' groups of the analyzed project.

\section{LITERATURE REVIEW}

\section{Context of social economy in infrastructure projects}

Considerations on social aspects of infrastructure arise from its nature. At a very basic level, infrastructure means assets, equipment or circulating capital that serve transport, telecommunications and energy provided to the public to meet social needs and expectations. More precise definitions include buildings and installations for education, health care, culture, research, and public administration needs. If well planned and efficiently implemented, infrastructure stimulates economic development. In theory, it can be delivered by public, private or combined providers. However, in practice, infrastructure usually needs public financing preceded by positive results of social cost-benefit analysis.

At a project level, following the EU Regulation No 1303/2013, more precise classifications can be taken into account, as a project can be defined as 
activities, work or services intended to accomplish a specific task with clearly identified targets (Guide to Cost-Benefit Analysis of Investment Projects, 2014).

Following the literature definitions, infrastructure projects refer to structures, systems and facilities that are a prerequisite to the effective functioning of the whole economy. As it is stated in the Guide to CostBenefit Analysis of Investment Projects (2014), in contrast to private financed projects which should generate revenue, infrastructure projects should bring added value which come from the Europe 2020 targets - in the fields of employment, innovation, education, social inclusion and energy. If the achievement of these goals is proven, the public funds contribution from the EU in co-financing the infrastructure project can be justified for projects with low expected profitability.

Infrastructure projects can vary in the type of land use (railway, waste water treatment plant, roads, etc.), type of intervention (upgrade, construction, etc.), location or service provided (cultural activities, cargo traffic, etc.). Summing up different categories, infrastructure projects can be divided into: transport (roads, railways, air, public transport, intermodal, etc.), environmental (water, sanitation, waste management, environmental remediation, recycling, etc.), social (education, health care, etc.), energy (low-carbon energy, renewable sources, etc.), and broadband investments foreseen as internet access.

Extracting the social context of infrastructure projects, it is a prerequisite to refer to social economy and its social capital. Social economy defines choices in terms of limited resources and social purpose. On the one hand, social economy includes economic activity shaped by relationships and social processes within the local and regional economy. On the other hand, social economy includes social processes shaped by economic activity. However, the main objective of social economy is to meet social needs, solve social dilemmas and create social innovations. The social economy covers aspects such as employment, social services and social cohesion. The modern social economy provides public goods and services as important tools of local development. Hence, all types of infrastructure projects fit well into the modern social economy.

The accomplishment of the aims of the social economy can be seen in the light of at least three essential dimensions, which include: professional and social integration, stimulating the local economy and social capital, which can have many meanings (Coleman, 1998; Działek, 2011; Sandefur \& Laumann, 1998; Sierocińska, 2011). Professional and social integration dimensions can be supported by infrastructure projects which include science and technology parks, technology incubators and accelerators. As stated in Poland 2030: The third wave of modernity (2013), social capital is the one which performs a variety of economic functions and is especially stimulated by infrastructure interventions to increase the presence and accessibility of culture in 
everyday life. Among the social capital drivers are projects which lead to the modernization and improvement of the equipment of existing infrastructure, for example, libraries. All the infrastructure projects co-financed by public funds, like EU funds, require job creation. Public intervention is justified, when the expected profitability of the project is medium or low ${ }^{3}$ and it is among the targets and objectives of EU Strategy. In the programming period 2007-2013, interventions were taken into account for projects like: ports, solid waste, roads, public transport, railways, water supply and waste water treatment plants (Guidance on the Methodology for Carrying out Cost-Benefit Analysis, 2006). Among the targets and objectives within the Europe 2020 Strategy (2010) were, for example, fully interconnected transport and cross-border energy networks.

Public financed infrastructure projects require social benefits and/or social capital in terms of the social value chain. Social capital stimulates, for instance, the effectiveness of the public sector in problem solving in relation to urbanization.

\section{Stakeholders and their role in the social impact value chain of the infrastructure project}

The general success of projects can be measured by economic indicators or financial compliance; however, infrastructure is increasingly measured by the accomplishment of the social and environmental expectations of its stakeholders. Measurement of infrastructure social goals is based on a changing role of stakeholders in the infrastructure process, as social perception and impact analysis of infrastructure in the social value chain is about stakeholders and their expectations.

The concept of stakeholders is older than it seems - some date it to the 1960s, theories relating to stakeholders became popular after the mid-1980s and most of them were and still are devoted to organizations (Aapaoja \& Haapasalo, 2014; Freeman, 1984; Mitchell, Agle \& Wood, 1997). Stakeholder theory evolved from a concept at a corporate level - firms managed within the value based rules (VBM - value based management) into a project level - sophisticated project management. However, the corporate perspective still dominates stakeholder research. Overwhelmingly the most popular definition is the one provided and updated by Freeman, where stakeholders are the ones who influence the corporate and are influenced by it. More examples of stakeholders' types and attitudes are presented in Table 1.

3 Projects with (Economic Net Present Value) ENPV $<0$. 
Table 1. Stakeholder types and attitudes

\begin{tabular}{ll}
\hline Source (Year) & Stakeholder types and attitudes \\
\hline Blair and Whitehead (1998) & Potential cooperation \\
Goodpaster (1991) & Potencial risk \\
Clarkson (1995) & Fiduciary \\
& Non-fiduciary \\
& Primary (core) \\
Mitchell et al. (1997), Bourne (2005) & Secondary \\
& Peripheral (fringe) - not visible \\
& Power \\
& Urgency \\
& Legitimacy \\
& Proximity \\
\hline
\end{tabular}

The concept of stakeholder management is more and more visible in infrastructure projects, but there is still a huge gap in effective stakeholder relations management (SRM), even though the potentially negative impact of stakeholders on infrastructure projects can be significant.

Stakeholders - their identification, typology, features, prioritization and behaviour analysis in infrastructure projects - are the key issues of the social value chain of infrastructure investments. The key issue is to understand the social value chain of an infrastructure project with a diverse and evolving role of stakeholders during the investment process. It means not only identifying the expectations (desired outcomes) of stakeholders, and the inputs and impact of the project properly, but also differentiating outputs from impacts in the value chain. The role of stakeholders is crucial, as they are the main beneficiaries of infrastructure. However, the identification, prioritization and management of evolving stakeholder groups is more complex than it seems to be. Figure 1 shows the social impact value chain divided into inputs, process, outputs and profits.

Final profits and targets of infrastructure are derived from stakeholders' expectations. However, there is a lot of misunderstanding about what the final long-term profits (results) of infrastructure should be. Between inputs invested to achieve desired outcomes and real outcomes of the project, there are outputs which come from the direct results of the investment process. (Outcome and impact ..., 2009). Because, in the whole value chain, outputs are assessed directly from the project and are the easiest ones to measure; and the primary task of infrastructure project assessment should be to figure out which outputs meet the desired outcomes and measure the outcomes in the best way. 


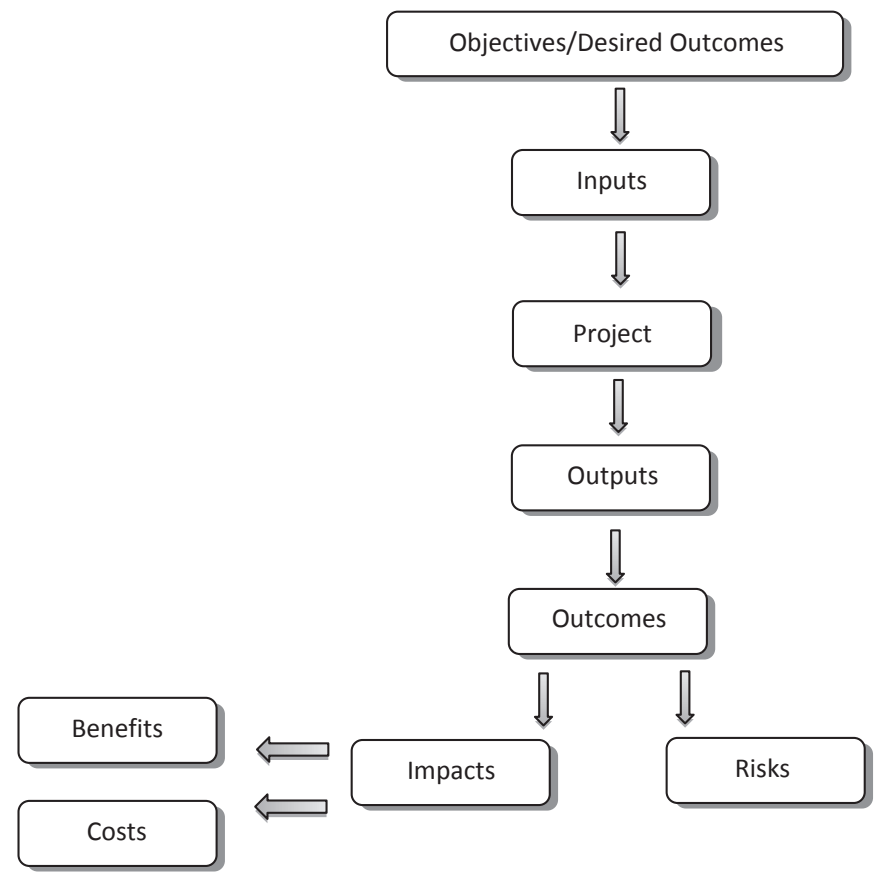

Figure 1. Social impact value chain Source: Based on Clark et. al (2004, p. 7).

Social outcomes set the medium or long term effects of project outputs and consist of risk and impact. Social impacts include the portion of infrastructure project outcomes experienced by stakeholders, excluding those which would happen without any intervention, and can be divided into: (1) processes, (2) change, (3) consequences. In practice, impacts are usually considered as positive (benefits) or negative (costs), primary or secondary long-term changes, or consequences of decisions taken which lead to development. It can also be stated as the social consequence of development or all the issues that directly or indirectly affect stakeholders. Social impacts include both intended and unintended outcomes of projects (Vanclay, 2002).

It is worth mentioning that there is no consensus in the literature, nor whether, in practice, impact defines the portion of cost and benefit outcomes or impact defines something different from outcomes. Table 2 shows a sample approach to differentiating outcomes from impacts of different infrastructure types.

In conclusion, there is no consensus of the final profits of infrastructure. However, impact indicators focus on the outcome level, while outputs focus on the direct effects of project implementation. As long as it is so difficult to measure the outcome level, because of insufficient expertise, time and costs, 
decision makers will focus on output level indicators and it will depend on their general knowledge which impacts are relevant for particular outputs (Burdge \& Vanclay, 1996).

Using the example of a new road infrastructure, output would include the number of cars using the new road and exemplary outcome could mean a higher quality of life.

The whole process of infrastructure impact analysis should be very precise and consider a wide range of stakeholders groups. However, Vanclay (2002) notices that trying to prepare a comprehensive list of social impact can be inutile. But, according to social impact theories, attentive and smart stakeholders management should be conducted to analyze, monitor and manage the intended and unintended social consequences, both positive and negative, of planned interventions (policies, programs, plans, projects) and any social change processes invoked by those interventions.

Social impact theories derive from the early 1970s and are based on public intervention which is prerequisite to ensure development and better

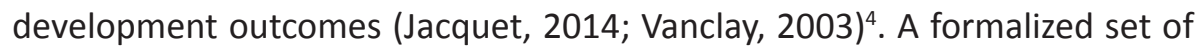
good practices was developed and formalized in the US in the 1970s as the Social Impact Assessment, however surveys of McKinsey \& Company state that the history of SIA started in the 1950s (McKinsey on Society). It seems that the term SIA was first used by the Department of the Interior when an Environmental Impact Statement was prepared (McKinsey on Society). As Jacquet notices (2014), social impact concerns were derived from widespread energy development, including oil, natural gas, coal and uranium. In 1992 the Inter-Organizational Committee on Guidelines and Principles for Social Impact Assessment (SIA) was formed to propose a set of principles. Then, after the past few years, the SIA idea expanded in an international context to increase the value of implementation processes.

It seems that most significant drivers for the expansion of Social Impact were the international agreements of Environmental Impact Assessments, the growing role of the World Bank, International Monetary Fund, International Finance Corporation (IFC) and other international finance providers which adopted The Equator Principles $s^{5}$ - risk management frameworks for managing environmental and social risks and impacts in large and industrial projects in a structured way.

\footnotetext{
4 Generally, impact assessments have been practiced for over 40 years, now with at least six well-established ones: Environmental Impact Assessment (EIA), Strategic Environmental Assessment (SEA), Policy Assessment, Social Impact Assessment (SIA), Health Impact Assessment (HIA) and Sustainability Assessment (Pope et al., 2013, p.1, 2). Fundamentals of impact assessment have roots in environmental issues and US National Environmental Policy Act (NEPA) dated on 1969. 5 Equator Principles were adopted by 85 financial institutions among 35 countries, covering over $70 \%$ of international Project Finance debt in emerging markets - Equator Principles Financial Institutions (EPFIs). Institutions operating in Poland have not adopted the principles. More info: http://www.equator-principles.com.
} 
A lot of international institutions like the World Bank or International Monetary Fund demand strict socio-economic profits and effects for the awarded money. Probably, the World Bank (WB) was the first institution to operationalize the concept of social outcomes. The aim of the Social Capital Initiative (SCl), funded by the Government in Denmark and launched by World Bank in 1996, was to assess the impact of social capital of development projects and to contribute to methodologies for practical tools in measuring the social impact and social capital (Brootaert \& Bastelaer, 2001). The Bank's current policies were issued over 20 years ago, and the latest social framework (Environmental and Social Framework) was approved on 4th of August 2016.

Table 2. Exemplary outcomes and impacts of different infrastructure projects

\begin{tabular}{lll}
\hline Outcomes & Impacts \\
\hline Roads & Lower road transport time & Specific impacts \\
Lower road transport costs & Greater economic accessibility: \\
Implementation and & access to roads - population living within \\
related to roads & x-kilometres of the road \\
Increased employment & use of public transportation (number of people \\
& using public transportation) \\
& business productivity (market return for traded \\
& goods, transfer to higher-value goods) \\
& Greater accessibility to social services (schools, \\
& health care, local governmental offices) \\
& environmental effects of road systems (soil \\
& erosion, lead and carbon pollution, market share \\
& for unleaded petrol) \\
& enhanced safety \& health linked to roads \\
& road deaths and injuries (number of deaths, road \\
& injuries) \\
& disease transmissions influenced by improved \\
& mobility \\
Intermediate impacts \\
Improved conditions for economic growth \\
Employment opportunities \\
Trade (volume and value of trade between \\
regions) \\
Enhanced Human Capital \\
School attendance \\
Health attendance (number of visits to health \\
centers, number of supervised births) \\
Global impacts \\
Economic Growth \\
Social Development \\
Poverty reduction \\
& \\
& \\
& \\
& \\
&
\end{tabular}




\begin{tabular}{|c|c|c|}
\hline & Outcomes & Impacts \\
\hline $\begin{array}{l}\text { Water/ } \\
\text { Sanitation }\end{array}$ & $\begin{array}{l}\text { Improved conservation and } \\
\text { preservation of water } \\
\text { Availability of water } \\
\text { (change in water levels) } \\
\text { Preservation of water } \\
\text { (protected areas) } \\
\text { Improved use of water and } \\
\text { sanitation } \\
\text { Irrigation requirements } \\
\text { (amount of water } \\
\text { necessary to produce food) } \\
\text { Water leakages (water lost } \\
\text { through water systems) } \\
\text { Recycling of water (amount } \\
\text { of recycled water) } \\
\text { Increased employment } \\
\text { due to construction and } \\
\text { maintenance } \\
\text { Improved quality of water } \\
\text { and sanitation } \\
\text { Pollution of water and } \\
\text { soil (level of chemicals, } \\
\text { minerals, metals, } \\
\text { pesticides, etc) } \\
\text { Treatment of waste water } \\
\text { Greater equity in allocation } \\
\text { of water and sanitation } \\
\text { (rate of connection to } \\
\text { water network to national } \\
\text { average) } \\
\text { Equity in allocation of } \\
\text { water between sectors } \\
\text { Increased affordability of } \\
\text { water and sanitation } \\
\text { Household expenditure on } \\
\text { water and sanitation } \\
\text { Cost of water for business }\end{array}$ & $\begin{array}{l}\text { Specific impacts } \\
\text { Improved water and sanitation health and } \\
\text { hygiene behavior lead by awareness } \\
\text { Increased access to safe water } \\
\text { Domestic access to safe water (number of } \\
\text { households connected to water network) } \\
\text { Business access to water (\% of industrial water } \\
\text { needs met) } \\
\text { Increased access to basic sanitation (number of } \\
\text { people with access to sanitation) } \\
\text { Specific/intermediate impacts } \\
\text { Improved conditions for economic growth } \\
\text { Intermediate impacts } \\
\text { Sustainable national water supply } \\
\text { Reduced rate of water related diseases }\end{array}$ \\
\hline
\end{tabular}

Source: Outcome and impact level indicators water and sanitation sector (2009), Outcome and impact level indicators road sector (2009).

Following F. Vanclay's presentations, among the formalized examples are: the World Bank Environmental and Social Framework, International Finance Corporation Performance Standards, OECD Guidelines on Multinational Enterprises, UN Principles for Responsible Investment, and UN Global Conduct (Vanclay, 2012). In contrast with some forms of impact assessment like environmental, which was adopted in the European SEA Directive 2001/42/EC, social and health issues are still not legally mandated 
in most jurisdictions (Pope et. al., 2013). Social aspects are categorized by: standards, assessments, codes of conduct or guidelines.

Unfortunately, there is still no sufficient data and methodology for modelling social outcomes, especially impacts. It allows for flexibility and context approaches, although cost-benefit methodology seems to be the most commonly implemented as an economic appraisal tool of infrastructure project evaluation. This can be confirmed by the obligatory use of the EU Guide to Cost-Benefit (2014) in all public financed investments projects.

\section{RESEARCH METHODS}

\section{Sample and data collection}

The subject of the research was the Exhibition and Congress Center of the Gdańsk International Fair Co, AmberExpo. This infrastructure project consists of exhibition halls, an office building with conference center and VIP area, a press center and service areas, parking and an exhibition area. The AmberExpo project was implemented in 2011-2012 by the investor, Gdańsk International Fair Co. The complex is an example of an infrastructure project in the third stage of an investment, i.e. the stage of use of an infrastructure facility. AmberExpo is operated by MTG, a company owned by the municipality and headed by the president of the city, which co-operates with the city council. Both the president and the councillors are directly elected by city residents every four years. The municipality favours participatory forms of urban governance. From this point of view, it is important to know how to assess the effects of managing an infrastructure project, which aims to improve the quality of life in society.

A self-report paper-and-pencil questionnaire was used to collect data from different Gdańsk International Fair Co stakeholders belonging to the following stakeholder groups: (FAM) firms located at AmberExpo; (FG) firms located in Gdańsk; (FL) firms located in Letnica; (MG) residents of Gdańsk; (ML) residents of Letnica; (MTG) employees of MTG; (OT) visitors (only from outside Gdańsk) at an event ("FIT Festival") held at AmberExpo in February 2016; (WT) firms (only from outside Gdańsk) participating in "FIT Festival". A total of 820 responses were collected, of which 23 were deemed incomplete. Consequently, 797 responses were used for further analysis. It should be noted that of our sample $57 \%$ were female. Moreover, $25 \%$ of respondents were aged 25 years or less, $20 \%$ were between 26 and 40 , and $55 \%$ were over 41. As for businesses, $70 \%$ of the firms in our sample employed less than nine workers, $27 \%$ employed between ten and 49 people, and $3 \%$ more than 50 . As regards the age of the firms, $8 \%$ were less than a year old, $35 \%$ were 
between one and five years old, 35\% were between six and 10 years old, and $22 \%$ were more than 11 years old.

The sampling procedure varied depending on the stakeholder group. Specifically, as for (MG) and (ML), we used a two-stage approach. The first stage consisted of randomly selecting a street. At the second stage, systematic sampling was applied to select a flat (i.e., every fifth flat). As for (FG), we randomly selected companies from a register, known as the National Official Register of the Territorial Division of the Country (TERYT). As for (FAM) and (FL), all firms (based on TERYT) were included (i.e., full sample). The same goes for (WT). As for (MTG), systematic sampling was used (i.e., every second employee). Finally, we applied accidental sampling to (OT).

\section{Measurement}

A key step in measuring the positive impact (social benefits) and negative impacts (social costs) of a project is to define a set that will be different for each project. Additionally, it should be noted that it is necessary to decompose social benefits and costs into external (objective) and subjective perceptions perceived by each stakeholder. The key thesis of the proposed approach is that the difference between social benefits and costs is always positive and thus increases the economic value of the project. Our study showed that project stakeholders often fail to identify all the benefits and costs, both external and subjective.

We measured outputs, outcomes as effects of outputs, positive impact - benefits (outcomes to stakeholders) and negative impacts - costs with the following items (Table 3):

Table 3. Items used to measure the social costs and benefits of the MTG stakeholders

\begin{tabular}{|c|c|c|c|}
\hline Outputs & $\begin{array}{l}\text { Outcomes as } \\
\text { effects of outputs }\end{array}$ & $\begin{array}{l}\text { Positive impact - } \\
\text { Benefits }\end{array}$ & $\begin{array}{l}\text { Negative impacts } \\
\text { - Costs }\end{array}$ \\
\hline $\begin{array}{l}\text { Local district } \\
\text { infrastructure } \\
\text { development } \\
\text { Transport } \\
\text { improvement } \\
\text { Access to events } \\
\text { Parks and green } \\
\text { areas } \\
\text { Playgrounds and } \\
\text { recreation areas }\end{array}$ & $\begin{array}{l}\text { Increase of real } \\
\text { estate market } \\
\text { value } \\
\text { Advertising spaces } \\
\text { Development of } \\
\text { local services } \\
\text { Tax increase } \\
\text { Increased } \\
\text { aesthetics of green } \\
\text { spaces }\end{array}$ & $\begin{array}{l}\text { Better education } \\
\text { facility } \\
\text { Better culture } \\
\text { access } \\
\text { Higher tourist } \\
\text { attractiveness of } \\
\text { the city } \\
\text { Integration of } \\
\text { business clusters }\end{array}$ & $\begin{array}{l}\text { Higher traffic } \\
\text { Higher pollution } \\
\text { Vibration and } \\
\text { noise from traffic } \\
\text { Newcomers to the } \\
\text { local community }\end{array}$ \\
\hline
\end{tabular}




\begin{tabular}{llll}
\hline Outputs & $\begin{array}{l}\text { Outcomes as } \\
\text { effects of outputs }\end{array}$ & $\begin{array}{l}\text { Positive impact - } \\
\text { Benefits }\end{array}$ & $\begin{array}{l}\text { Negative impacts } \\
\text { - Costs }\end{array}$ \\
\hline Very well & High traffic & Better quality of \\
equipped & Lower road & life \\
Amber Expo & transport costs & Higher tax \\
infrastructure & Increased level & incomes to local \\
New industrial & of water and & budget \\
building & sanitation & Enhanced safety \\
Rebuilding of & Better & Greater economic \\
water system & communication & accessibility \\
preservation & accessibility & Greater \\
Renovation of & Better public & accessibility to \\
local railway & transport access to & local services \\
station & the district & Employment \\
& Culture centre & opportunities \\
\hline
\end{tabular}

The fractions of the items/variables for different group of stakeholders are presented in Table 4.

According to the given responses, $100 \%$ of firms located exactly at Amber Expo perceive outputs of the new infrastructure Exhibition Centre, but only $18 \%$ of firms located in the Gdańsk area. In the case of outcomes as effects of outputs, the highest fraction $72 \%$ refer to employees of MTG and almost the same (65\%) refer to residents of Letnica. The lowest level of outcomes was noticed by firms located in the Gdańsk area (21\%).

Table 4. Fractions of the items of the MTG stakeholders (\%)

\begin{tabular}{|c|c|c|c|c|c|}
\hline Stakeholder & $\mathbf{n}$ & Outputs & $\begin{array}{l}\text { Outcomes } \\
\text { as effects of } \\
\text { outputs }\end{array}$ & $\begin{array}{l}\text { Positive } \\
\text { impacts - } \\
\text { Benefits }\end{array}$ & $\begin{array}{l}\text { Negative } \\
\text { impacts - } \\
\text { Costs }\end{array}$ \\
\hline FAM & 4 & 100 & 50 & 75 & 25 \\
\hline FG & 39 & 18 & 21 & 18 & 18 \\
\hline $\mathrm{FL}$ & 37 & 49 & 54 & 51 & 16 \\
\hline MG & 400 & 31 & 27 & 16 & 8 \\
\hline $\mathrm{ML}$ & 113 & 52 & 65 & 58 & 12 \\
\hline MTG & 25 & 52 & 72 & 60 & 20 \\
\hline OT & 106 & 27 & 27 & 39 & 28 \\
\hline WT & 65 & 49 & 37 & 25 & 32 \\
\hline
\end{tabular}

The Spearman correlation ratio, which equals 0.82 , reveals that there is a high positive relationship between perception of outputs and outcomes among analyzed stakeholders groups. It allows us to formulate the hypothesis 
that the higher the level of outputs (and outcomes) perception by the stakeholders group, the better the perception of positive impacts - benefits (respectively Spearman ratio equals 0.85 and 0.78 ). There is no evident relation between outputs (outcomes) and negative impacts (costs).

In view of the foregoing, the Social Relation Management team should consider stronger interests in reference to those stakeholders who, to a greater extent, notice outputs of the project. This conclusion is consistent with the theory, which states that positive outcomes should maximize rather than minimize negative effects.

\section{ANALYSIS}

The present study draws on data collected among stakeholders of Gdańsk International Fair Co (MTG - a company that is controlled by the municipality of Gdańsk (Poland) and operates a big exhibition centre called AmberExpo). This facility, financed by taxpayer's money, is located in Letnica, one of the city's most disadvantaged neighbourhoods. We proposed to investigate the relationship between MTG and its stakeholders through the lens of social costs and benefits analysis (Dompere, 1995), which may be viewed as a general framework for the analysis of private and social decisions to correctly account for possible costs and benefits.

Cost-benefit analysis (CBA) is the main tool used in welfare economics in order to assess whether a project should be undertaken (Levin \& McEwan, 2001). The criterion for a project to be considered is that its benefits outweigh its costs 6 . The question, however, is broader than financial costs and is whether benefits that are not reflected in the 'market terms' such as social effects should be taken into account?

Social costs-benefits analysis (SCBA) refers to cases where the project has a broad impact across society. Such projects have one set of costs and benefits that may be measured in terms of their price in money and also changes in individual utility and total social welfare that is not easily quantifiable. As an idea SCBA is extremely simple: evaluate costs $C$ and benefits $B$ for the project under consideration and proceed with it if, and only if, benefits match or exceed the costs. In practice SCBA is quite complex. The complexity of the SCBA is related to a number of different factors that are difficult to measure. We can state that social costs and benefits:

1) Usually relate to different sets of stakeholders. So the way of aggregation and comparison of different costs and benefits across different sets of stakeholders should be done separately.

6 In some countries, undertaking a cost-benefit analysis for appraising public projects is mandatory, for example the US Presidential Executive Order 12291, or HMT guidance in the UK. 
2) May occur at different points in time. In this case we need to compare the value of outcomes at different points in time.

3) May relate to different types of products (goods or services or others) and it may be difficult to compare their relative values.

4) May be (and usually are) uncertain.

5) May be difficult to price and, as a result, there may be different effects of pricing.

As we can see from the above, the process of pricing all of the factors that should be involved in a costs and benefits analysis for a given project is complex and difficult to quantify. Furthermore, this quantification only makes sense on a case-by-case basis. It is not difficult to note, for example, that there is a vast difference between the construction of a road and the construction of sewage treatment plants.

\section{DISCUSSION}

A wide range of issues come with social costs and benefits in the social impact value chain. The greatest problem of social costs and benefits is that the impact is difficult to predict and quantify and can be taken into account differently by the authorities, decision makers and project developers. Social impacts can vary in every project, so modelling is still a current and important research topic. However, many of the social impacts of the planned intervention (infrastructure projects) can be well predicted.

The next obstacle is to understand and differentiate outputs from costs and benefits. Many costs and benefits are misleading in their direct effects on projects. The distribution of costs and benefits of development and infrastructure projects is not equal across the community. So, identifying social impact is the main concern with the social distribution of costs and benefits among the stakeholders.

Most projects bring newcomers to the community (new community stakeholders) with differences in values, attitudes and behaviours, so the project generates additional social values. One of the findings and discussion issues is that some impacts can be perceived as negative (costs) by some members of the community, but positive (benefits) by others, as it is the subject of individual judgements. The statement whether the impacts are positive or negative may be more complex, as the judgement may change during the investment process. Some impacts may also be excluded. 


\section{CONCLUSION}

This research work, while applying social costs-benefits analysis to the explanation of stakeholder behaviour, has incorporated the social impact of the infrastructure project into the analysis and conceived of stakeholder relationship as inherently nested. Social impact is considered as a consequence or effect of decisions or interventions undertaken which lead to development. It can also be considered as a social consequence of development or the issues that directly or indirectly affect people. The greatest problem of social costs and benefits is that the impact is difficult to predict and quantify and can be taken into account differently by authorities, decision makers and project developers. At the same time, our study offers several practical insights of particular interest to municipalities and municipality-controlled companies planning to improve the way they manage the relationship with their diverse stakeholders. The main purpose of this paper was to identify and demonstrate a concept of the social impacts of infrastructure projects and as a result we obtained a set of outputs and outcomes which demonstrates different social impacts (costs and benefits) for the project. Applying a measure of consistency reveals that there is a high positive relationship between the perception of outputs and outcomes among analyzed stakeholders groups. It allows us to formulate the hypothesis that the higher the level of outputs (and outcomes) perception by the stakeholders group, the better the perception of positive impact - benefits. So Social Relation Management should consider stronger interests in reference to those stakeholders who notice outputs of the project to a greater extent. This conclusion is consistent with the theory, which states that positive outcomes should maximize rather than minimize negative effects.

As in the vast majority of research projects, this study has a number of limitations that ought to be acknowledged. One of them is that it relies solely on self-reports, which suggests that caution is in order while interpreting and generalizing the findings. But these limitations provide opportunities for further research.

\section{Acknowledgments}

The article came into being within a research project supported by the National Centre of Research and Development under the programme 'Social Innovations' (IS-2/88/NCBR/2015); title: Innovative Model of Socioeconomic Benefits and Costs in Infrastructural Projects. 


\section{References}

Aapaoja, A., \& Haapasalo, H. (2014). A framework for stakeholder identification and classification in construction projects. Open Journal of Business and Management, 2, 43-55.

Burdge, R., \& Vanclay, F. (1996). Social impact assessment: A contribution to the state of the art series. Impact Assessment, 14(1), 59-86.

Clark, C., Rosenzweig, W., Long, D., \& Olsen, S. (2004). Double Bottom Line Project Report: Assessing Social Impact In Double Bottom Line Ventures. Rockefeller Foundation. Retrieved from http://www.riseproject.org/DBL Method_Catalog.pdf

Coleman J.S. (1998). Social capital in the creation of human capital. American Journal of Sociology, 94, 95-120.

Dompere, K.K. (1995). The theory of social costs and costing for cost-benefit analysis in a fuzzy-decision space. Fuzzy Sets and Systems, 76(1), I-24.

Działek J. (2011). Kapitał społeczny - ujęcie teoretyczne i praktyka badawcza. Studia Regionalne i Lokalne, 3(45), 100-118.

Europe 2020. A European Strategy for smart, sustainable and inclusive growth. European Commission, COM (2010) 2020, 3.3.2010, Brussels.

Freeman, R.E. (1984). Strategic Management: A Stakeholder Approach. Boston: Pitman.

Freeman, R.E., Harrison, J.S., Wicks, A.C., Parmar, B.L., \& de Colle, S. (2010). Stakeholder Theory: The State of the Art. Cambridge: Cambridge University Press.

Grootaert, Ch., \& Bastelaer, T. (2001). Understanding and measuring social capital: A synthesis if findings and recommendations from the social capital initiative. Social Capital Initiative Working Paper, 24.

Guidance on the Methodology for Carrying out Cost-Benefit Analysis (2006). The New Programming Period 2007-2013, European Commission. Working Document, 4.

Guide to Cost-Benefit Analysis of Investment Project, Economic appraisal tool for Cohesion Policy 2014-2020 (2014). European Commission, Working Document, 15-40.

Hartmann, A., \& Hietbrink, M. (2013). An exploratory study on the relationship between stakeholder expectations, experiences and satisfaction in road maintenance. Construction Management and Economics, 31(4), 345-358.

Jacquet, J.B. (2014). A Short History of Social Impact Assessment, Department of Sociology and Rural Studies. Montana: South Dakota State University.

Levin, H.M., \& McEwan, P.J. (2001). Cost-Effectiveness Analysis. Methods and Applications. London: Sage Publications.

Mainardes, E.M., Alves, H., \& Raposo, M. (2012). A model for stakeholder classification and stakeholder relationships. Management Decision, 50(10), 1861-1879.

McElroy, B., \& Mills, C. (2007). Managing stakeholders. In J.R. Turner (Ed.), Gower Handbook of Project Management (pp. 757-777). Aldershot: Gower Publishing. 
Mitchell, R.K., Agle, B.R., \& Wood, D.J. (1997). Toward a theory of stakeholder identification and salience: Defining the principle of who and what really counts. The Academy of Management Review, 22(4), 853-886.

Outcome and impact level indicators road sector (2009). EC External Services Evaluation Unit, Working Paper.

Outcome and impact level indicators water and sanitation sector (2009). EC External Services Evaluation Unit, Working Paper.

Phillips, R. (2003). Stakeholder Theory and Organizational Ethics. San Francisco, CA: Berrett-Koehler Publishers Inc.

Polska 2030. Trzecia fala nowoczesności. Długookresowa Strategii Rozwoju Kraju (2013). Warszawa: Ministerstwo Administracji i Cyfryzacji.

Pope, J., Bond, A., Morrison-Saunders, A., \& Retief, F. (2013). Advancing the theory and practice of impact assessment: Setting the research agenda. Environmental Impact Assessment Review, 41, 1-9.

Sandefur, R., \& Laumann, E.O. (1998). A paradigm for social capital. Rationality and Society, 10, 481-501.

Sierocińska, K. (2011). Kapitał społeczny. Definiowanie, pomiar, typy. Studia Ekonomiczne 1(68), 69-86.

The Green Book: Appraisal and Evaluation in Central Government. (2016). London: Treasury Guidance, HM Treasury,

US Presidential Executive Order 12291 (1981). The National Archives and Records Administration.

Vanclay, F. (2003). International principles for social impact assessment. Impact Assessment and Project Appraisal, 21(1), 5-11.

\section{Abstract (in Polish)}

Celem artykułu była identyfikacja i weryfikacja koncepcji wpływu korzyści i kosztów społecznych na projekty infrastrukturalne. Zaproponowana metodyka badań to krytyczna analiza i przeglad literatury, kolejno jakościowe badania fokusowe oraz analiza wyników z badań sondażowych realizowanych w ramach projektu wspótfinansowanego ze środków Narodowego Centrum Badań i Rozwoju. Realizacja skutecznych i właściwie dobranych projektów infrastrukturach warunkuje rozwój ekonomiczny, w tym społeczny. Niestety, większość projektów infrastrukturalnych nie przynosi pozytywnych efektów finansowych. Stad też w ocenie projektów przyjmuje się aspekty ekonomiczne, które poza aspektami finansowymi, obejmujq w szczególności kwestie społeczne. Aspekty społeczne sa jednak trudne do prognozowania. Ważnym aspektem pomiaru korzyści społecznych jest ich niemierzalność. Jednocześnie podkreślić należy, że odpowiednia dekompozycja społecznych korzyści i kosztów na obiektywne i subiektywne, umożliwia porównanie tych dwóch kategorii i tym samym wskazanie, że przewaga korzyści na kosztami społecznymi zwiększa ekonomicznq wartości projektu, natomiast w sytuacji przewagi kosztów na korzyściami wspomnianq wartość ekonomicznq należy pomniejszyć. Może to mieć znaczenie $w$ procesie podejmowania decyzji o uruchamianiu danego projektu infrastrukturalnego bqdź przy ocenie projektu infrastrukturalnego w fazie eksploatacji.

Keywords: projekt infrastrukturalny, wpływ społeczny, analiza korzyści i kosztów. 


\section{Biographical notes}

Joanna Próchniak - Ph.D., Assistant Professor of Economy at the Faculty of Management, University of Gdańsk. Her research interests focus on: financing in the SME's sector, value based management with a focus on business process offshoring and social aspects in creating corporate value (for example: social value, social impact, social corporate responsibility, non-financial reporting). She conducts classes in business economics, financing SME's, and venture capital.

Anna Zamojska - Ph.D., Associate Professor of Economy and Finance at the Faculty of Management, University of Gdańsk where she conducts research and courses in Econometrics, Forecasting and Statistics. Currently, she is focused on the following issues: Uncertainty Modelling, Corporate Governance and Financial Performance of Companies, Econometrics of Financial Markets. She has worked in industry and business consulting for many years, specializing in the field of quantitative research and analysis. 


\title{
Theoretical and Methodical Aspects of Crowdsourcing: Effectiveness and Its Measuring. A Conceptual Paper
}

\section{Regina Lenart-Gansiniec ${ }^{1}$}

\begin{abstract}
In our times, a growing interest of organizations, including also the public ones, in crowdsourcing, can be observed. It enables to acquire knowledge located in virtual communities. However, despite many benefits, crowdsourcing initiatives very often fail. Therefore, a need for their evaluation is recognized. Nonetheless, in the subject literature, a shortfall of criteria and methods of evaluating crowdsourcing may be observed. The existing proposals do not ensure a comprehensive picture of crowdsourcing, and they do not take into account its multidimensionality. The article is intended for a presentation of the ways of evaluating crowdsourcing and an original proposal of a list of indicators, which may be used for evaluating crowdsourcing in public organizations. The article presents the original proposal of activities, by which it is possible to assess the degree of implementation of the adopted tasks and determine the level of obtained crowdsourcing results. The conducted research allowed to recognize that it is possible to measure crowdsourcing results using quantitative and qualitative indicators. A prerequisite for selecting the appropriate means is first of all to indicate the purposes for which crowdsourcing should be used. Keywords: crowdsourcing, effectiveness, measurement, public organizations.
\end{abstract}

\section{INTRODUCTION}

Crowdsourcing is a relatively new notion, but one which is nonetheless raising more and more interest with researchers. In short, it means a selection of functions, which have until present been performed by employees, are transferred in the form of an open on-line call, to an undefined community - the crowd. For many organizations, crowdsourcing is an opportunity to achieve or increase competitive advantage (Rouse, 2010; Whitla, 2009). It is

1 Regina Lenart-Gansiniec, Ph.D., Jagiellonian University, ul. Łojasiewicza 4, 30-348 Kraków, Poland, e-mail: regina. lenart-gansiniec@uj.edu.pl. 
also used by public organizations in their activity. What is important, is that the existing crowdsourcing activity of public organizations in Poland enables one to ascertain that it may generate considerable interest among the citizens and serve as a source of innovations: an example is the Otwarta Warszawa (Open Warsaw) platform: 16, 600 registered users, 1,147 ideas generated by the crowd, out of which 24 have been implemented.

Regardless of the premises for making a decision about crowdsourcing, organizations must be aware of the fact that as a result it may bring some benefits, but also generate some specific losses. Taking into account the high percentage of crowdsourcing initiatives' failure, it is worth considering measuring crowdsourcing. However, a shortage and fragmentariness in the scope of the methodology of measuring the effectiveness of crowdsourcing may be observed. In addition, organizations often make use of crowdsourcing without fully understating its effectiveness (Bayus, 2013). A lack of measurement may make achieving the goal of crowdsourcing impossible. This subject matter seems to be important - the evaluation of crowdsourcing seems to be of importance to public organizations. Especially since it is even demanded that the actions of public organizations are evaluated (Frączkiewicz-Wronka, 2013).

The aim of this article is to present the ways of evaluating crowdsourcing and an original proposal of a list of indicators, which may be used for evaluating crowdsourcing in public organizations. The article is composed of three parts. In the first one, information on the essence and notion of crowdsourcing and its importance to a public organization is presented. The second part is devoted to measuring the effectiveness of crowdsourcing in public organizations. An original proposal of measures, based on which one may carry out an evaluation of the degree of realization of assumed tasks and specify the level of the achieved crowdsourcing results, is presented in the article.

\section{LITERATURE REVIEW}

\section{The essence and notion of crowdsourcing}

The first time the notion of crowdsourcing appeared in the subject literature was in 2006 by J. Howe. He defined crowdsourcing as "the act of a company or institution taking a function once performed by employees and outsourcing it to an undefined (and generally large) network of people in the form of an open call. This can take the form of peer-production (when the job is performed collaboratively), but is also often undertaken by sole individuals" (Howe, 2006). 
With time new definitions of crowdsourcing started to appear, including the role of the Internet as a specific moderator (Quinn \& Bederson, 2011; Brabham, 2013). It started to be linked with establishing cooperation and relations with virtual communities (Yang, Adamic \& Ackerman, 2008), and further making use of their wisdom (Surowiecki, 2004) to solve problems (Vukovic, 2009), creating innovative solutions (Sloane, 2011), and open source software (Rouse, 2010). Selected definitions were presented in Table 1.

Table 1. Selected definitions of crowdsourcing

\begin{tabular}{|c|c|c|}
\hline Date & $\begin{array}{l}\text { Author/ } \\
\text { authors }\end{array}$ & Definition \\
\hline 2006 & $\begin{array}{l}\text { Reichwald, } \\
\text { Piller }\end{array}$ & $\begin{array}{l}\text { Interactive creation of values: collaboration between the } \\
\text { organization and the users in the development of a new } \\
\text { product }\end{array}$ \\
\hline 2008 & $\begin{array}{l}\text { Chanal, } \\
\text { Caron-Fasan }\end{array}$ & $\begin{array}{l}\text { Opening of the innovation process in the organization in } \\
\text { order for integration through a competence network }\end{array}$ \\
\hline 2008 & Howe & $\begin{array}{l}\text { Act of a company or institution taking a function once } \\
\text { performed by employees and outsourcing it to an undefined } \\
\text { (and generally large) network of people in the form of an } \\
\text { open call. This can take the form of peer-production (when } \\
\text { the job is performed collaboratively), but is also often } \\
\text { undertaken by sole individuals }\end{array}$ \\
\hline 2008 & $\begin{array}{l}\text { Kleeman et } \\
\text { al. }\end{array}$ & $\begin{array}{l}\text { Form of integration of users or consumer in internal } \\
\text { processes of value creation. The essence of crowdsourcing } \\
\text { is an intended mobilization with allocation of commercial } \\
\text { exploration of creative ideas and other form of work } \\
\text { performed by the consumer }\end{array}$ \\
\hline 2008 & Yang et al. & Making use of a virtual community to transfer tasks \\
\hline 2009 & $\begin{array}{l}\text { DiPalantino, } \\
\text { Vojnovic }\end{array}$ & $\begin{array}{l}\text { Methods while using an open call to encourage communities } \\
\text { to solve problems }\end{array}$ \\
\hline 2009 & $\begin{array}{l}\text { Poetz, } \\
\text { Schreier }\end{array}$ & $\begin{array}{l}\text { Outsourcing of the phase of generating ideas to potentially } \\
\text { large and unknown groups of people in the form of an open } \\
\text { call }\end{array}$ \\
\hline 2009 & Vukovic & $\begin{array}{l}\text { A new production model widespread on the Internet in } \\
\text { which people collaborate in order to complete a task }\end{array}$ \\
\hline 2009 & Whitla & $\begin{array}{l}\text { The process of outsourcing of an organization's activity to } \\
\text { the virtual community. The process of organising work in } \\
\text { which the organization offers payment for realization of } \\
\text { tasks by the crowd members }\end{array}$ \\
\hline 2010 & Heer, Bostok & $\begin{array}{l}\text { A relatively new phenomenon in which Internet workers } \\
\text { carry out one or more micro-tasks, often for a micro- } \\
\text { payment ranging from } \$ 0.01 \text { to } \$ 0.10 \text { for the tasks }\end{array}$ \\
\hline 2010 & $\begin{array}{l}\text { Burger- } \\
\text { Helmchen, } \\
\text { Penin }\end{array}$ & $\begin{array}{l}\text { The way in which the organization gains access to external } \\
\text { knowledge }\end{array}$ \\
\hline
\end{tabular}




\begin{tabular}{|c|c|c|}
\hline Date & $\begin{array}{l}\text { Author/ } \\
\text { authors }\end{array}$ & Definition \\
\hline 2010 & $\begin{array}{l}\text { Buecheler } \\
\text { et al. }\end{array}$ & A specific case of collective intelligence \\
\hline 2010 & $\begin{array}{l}\text { La Vecchia, } \\
\text { Cisternino }\end{array}$ & Tools for solving problems in the organization \\
\hline 2010 & Ling & A new business model of innovation through the Internet \\
\hline 2010 & $\begin{array}{l}\text { Mazzola, } \\
\text { Distefano }\end{array}$ & $\begin{array}{l}\text { Purposeful mobilization through web } 2.0 \text {, creation of } \\
\text { innovative ideas, incentives for problem solving, where users } \\
\text { coming forward voluntarily are taken into account by the } \\
\text { organization in the process of solving internal problems }\end{array}$ \\
\hline 2010 & $\begin{array}{l}\text { Oliveira et } \\
\text { al. }\end{array}$ & $\begin{array}{l}\text { A way of outsourcing to the crowd tasks related to the } \\
\text { creation of intellectual assets, often together in order } \\
\text { for easier access to the necessary palette of skills and } \\
\text { experience }\end{array}$ \\
\hline 2011 & $\begin{array}{l}\text { Alonso, } \\
\text { Lease }\end{array}$ & $\begin{array}{l}\text { Outsourcing of tasks to a large group of people rather than } \\
\text { assigning these tasks to the employees or contractors at } \\
\text { home }\end{array}$ \\
\hline 2011 & $\begin{array}{l}\text { Bederson, } \\
\text { Quinn }\end{array}$ & $\begin{array}{l}\text { People devote themselves to perform Internet tasks } \\
\text { managed by organizations }\end{array}$ \\
\hline 2011 & Doan et al. & A method of a general purpose of solving problems \\
\hline 2011 & Grier & $\begin{array}{l}\text { A way of making use of the Internet to employ a large } \\
\text { number of dispersed workers }\end{array}$ \\
\hline 2011 & $\begin{array}{l}\text { Heymann, } \\
\text { Garcia- } \\
\text { Molina }\end{array}$ & $\begin{array}{l}\text { Acquiring one or more Internet users to remote } \\
\text { performance of work }\end{array}$ \\
\hline 2013 & Brabham & $\begin{array}{l}\text { A way of solving problems, as well as a model of production, } \\
\text { in which, in order to achieve goals characteristic of an } \\
\text { organization, collective intelligence of Internet communities } \\
\text { is used. }\end{array}$ \\
\hline
\end{tabular}

Source: Lenart-Gansiniec (2017, pp. 25-34); Estelles Arolas \& González-Ladrón-De-Guevara (2012, pp. 189-200).

A review of the selected definitions of crowdsourcing enables one to ascertain that it is defined and formulated in various ways in the literature. Despite the proliferation of the considerations on crowdsourcing, there is no agreement as to the definition of crowdsourcing. It is interpreted not only as a way to solve problems (Doan, Ramakrishnan \& Halevy, 2011; Brabham, 2008) or a method for collecting ideas (Kleeman, Voss \& Rieder, 2008), but also as a phenomenon which accompanies all expressions of the technology Web 2.0 (Andriole, 2010). Crowdsourcing is therefore, a difficult concept, often vague, capacious, and complex (Estellés-Arolas \& González-Ladrónde-Guevara, 2012). Sivula and Kantola, in their accurate formulation of the issue of defining crowdsourcing, mention that it includes the human factor. 
This means that defining crowdsourcing alone is a challenge for researchers (Sivula \& Kantola, 2015).

A synthesis of the existing scientific output enables one to formulate a definition of crowdsourcing. Taking the above into account, based on analyses of various definitions, the following definition of crowdsourcing has been proposed: crowdsourcing is a way to engage by the organization, through an online crowdsourcing platform, a non-specified, dispersed group of people to realise various tasks, whereby each party obtains certain benefits.

Crowdsourcing is a relatively new concept, which is constantly developing - there is however a lack of comprehensive research. According to one of the most frequently quoted researchers of crowdsourcing, Zhao and Zhu (2014), during crowdsourcing measurement three perspectives should be considered, i.e. the participant, the crowdsourcing platform, and the organization. Such an approach to the measurement is also shared by Soliman (2014). Despite recommendations and indications, research is limited to one level of crowdsourcing chosen by the researchers. Not without importance are also crowdsourcing phases. Most often the following phases are pointed out: preparation, initiation, generation, evaluation, and implementation (Gassmann, Daiber \& Muhdi, 2010). In the preparation phase the identification of the problem, the defining of tasks which the organization wants to hand over to the virtual community, and defining the target group, all take place. The initiation phase includes: developing a project for collaboration with the virtual community, schedule, preparing an open call to the virtual community, selecting motivators, criteria for evaluating the submitted ideas, and ways to protect intellectual property. The generation phase concerns the incoming ideas, coordination, and entering into interactions with the virtual community. In the evaluation phase verification of the received solutions and ideas according to the criteria defined earlier, selection of the best solutions, and granting awards takes place. The closing stage is the implementation phase in which the organization informs the virtual community about implementing ideas acquired within crowdsourcing, carries out the implementation, possible commercialization, and makes a decision on continuing collaboration with the virtual community.

\section{Crowdsourcing in public organization management}

Since 2008 we have been observing tendencies to incorporate crowdsourcing by public organizations into their activity. There are many various crowdsourcing initiatives (Table 2). Taking into account the existing crowdsourcing classifications an attempt was made to integrate them into four categories, types, or areas of usage: (1) Problem solving (collective intelligence, wisdom of the crowd); (2) Rating ready solutions (crowdvoting, 
crowdrating); (3) Raising money (crowdfunding); (4) Creating creative contents, co-creation (crowdcreation, user-generated content). This division makes reference to the results obtained by other researchers (Hudson-Smith et al., 2009; 2012; Rosen, 2011; Alonso \& Mizzaro, 2012; Chandler \& Kapelner, 2013; Cabiddu, Lui \& Piccoli, 2013; Hossain \& Kauranen, 2015).

Table 2. Selected examples of crowdsourcing initiatives realised by public organizations

\begin{tabular}{|c|c|c|c|}
\hline Type & Examples & How does it work? & Potential Usage \\
\hline Broadcast search & White House SAVE Award & $\begin{array}{l}\text { The organization hands } \\
\text { over problems to the } \\
\text { crowd asking them to } \\
\text { search for ideas and } \\
\text { solutions }\end{array}$ & $\begin{array}{l}\text { Identification of new } \\
\text { solutions to problems, } \\
\text { e.g. improvement of } \\
\text { clerks' work }\end{array}$ \\
\hline $\begin{array}{l}\text { Peer-vetted } \\
\text { creative production }\end{array}$ & $\begin{array}{l}\text { Open Data, Dear Mr. } \\
\text { President, Challenge.gov, } \\
\text { Change by Us, Amsterdam } \\
\text { Opent, Medellin, Otwarta } \\
\text { Warszawa, Dobre Pomysły, } \\
\text { Next Stop Design, Logo } \\
\text { for the Police in Poland, } \\
\text { logo for Muzeum Żołnierzy } \\
\text { Wyklętych in Ostrołęka, idea } \\
\text { for developing a crossroads } \\
\text { in Salt Lake City, National } \\
\text { Defence Ministry - idea for } \\
\text { the name of an army truck, } \\
\text { constitution in Iceland, } \\
\text { Share an Idea, Ministry of } \\
\text { Environment and the Future } \\
\text { Commission in Finland: } \\
\text { change of regulations of } \\
\text { the act on road traffic, } \\
\text { Ministry of Justice in Brazil: } \\
\text { act on cyberspace, Paris: } \\
\text { Madame La Maire, j'ai une } \\
\text { idée" (Madame mayor, I have } \\
\text { an idea), Plamus, Malaysia: } \\
\text { Myldea (Ministry of Science, } \\
\text { Technology and Innovation), } \\
\text { Genovasi Challenge (National } \\
\text { Innovation Agency), MY } \\
\text { Innovation Tree (Malaysian } \\
\text { Productivity Corporation), } \\
\text { Budget2014 (Finance } \\
\text { Ministry), Melbourne } \\
\text { (futuremelbourne.com.au), }\end{array}$ & $\begin{array}{l}\text { The organization } \\
\text { encourages web users to } \\
\text { generate new ideas, solve } \\
\text { problems of an image, } \\
\text { social, and political nature }\end{array}$ & $\begin{array}{l}\text { Obtaining of ready } \\
\text { designs of logotypes, } \\
\text { names, plans for } \\
\text { developing of urban } \\
\text { space, strategies }\end{array}$ \\
\hline
\end{tabular}




\begin{tabular}{|c|c|c|c|}
\hline Type & Examples & How does it work? & Potential Usage \\
\hline $\begin{array}{l}\text { Knowledge } \\
\text { discovery and } \\
\text { management }\end{array}$ & $\begin{array}{l}\text { We the People, FixMyStreet, } \\
\text { SeeClickFix, NaprawmyTo. } \\
\text { pl, San Jose Mobile City Hall, } \\
\text { Did You Feel It?, Ushahidi, } \\
\text { Kidenga, POPVOX }\end{array}$ & $\begin{array}{l}\text { The organization } \\
\text { encourages the Internet } \\
\text { community to hand over } \\
\text { their opinions, judgments } \\
\text { on a given subject, analyse } \\
\text { information, notify about } \\
\text { problems }\end{array}$ & $\begin{array}{l}\text { Reporting about } \\
\text { occurring threats, } \\
\text { problems, }\end{array}$ \\
\hline $\begin{array}{l}\text { Distributed human } \\
\text { intelligence tasking }\end{array}$ & mTurk.com & $\begin{array}{l}\text { The organization gives } \\
\text { a request to the crowd } \\
\text { connected with carrying } \\
\text { out of a specific task }\end{array}$ & $\begin{array}{l}\text { Processing, analysing of } \\
\text { a big quantity of data, } \\
\text { arranging of information, } \\
\text { creating registers }\end{array}$ \\
\hline Crowdfunding & $\begin{array}{l}\text { Citizinvestor, Neighborly, } \\
\text { Spacehive }\end{array}$ & $\begin{array}{l}\text { The organization directs } \\
\text { to the crowd a request for } \\
\text { funds for the realization } \\
\text { of an endeavour for the } \\
\text { inhabitants }\end{array}$ & $\begin{array}{l}\text { Financing of construction } \\
\text { designs, social } \\
\text { infrastructure facilities }\end{array}$ \\
\hline
\end{tabular}

The selected examples of crowdsourcing initiatives presented above show that crowdsourcing in public organizations is becoming more and more popular. What is more, one may attempt to ascertain that, although in Poland it is in the early development phase, it is becoming almost an obligation abroad (and especially in the United States). The biggest interest is raised by encouraging the crowd to generate new ideas, test products, services, and solve various problems. It seems that crowdsourcing facilitates the process of collective designing. It is a solution which enables the realization of the demands of an open government by public organizations.

\section{Crowdsourcing and its measuring}

Effectiveness, both in the vernacular and in the subject literature, is understood and defined in various ways. In the foundation of management sciences, it is defined as an action or way of action which, "leads to an effect intended as a goal" (Kotarbiński, 1969) where the goal is understood as a state of the reality which the entity wishes to achieve through action. And therefore, it is treated as a category, which enables obtaining information about the usefulness of some action in the future. Those actions or ways of acting should be defined as effective, which enable or cause reaching a goal. It should be remembered that effectiveness is gradable and the measurement of effectiveness is the degree to which you reach all the final goals of an action. Therefore, it needs to be borne in mind that the fact of possessing a crowdsourcing platform alone does not decide about the success of the whole initiative. It is important to define the goal, criteria, and measurement indicators (Krawiec, 2014).

One may search in vain the methods related to crowdsourcing in the literature. Only a few publications about this topic may be found in the literature, however they mainly focus on the factors on which crowdsourcing effectiveness 
depends on. Nonetheless, a statement appears that crowdsourcing actions depend to a large extent on a thought over plan (Krawiec, 2014). In the opinion of Estellés-Arolas and González-Ladrón-de-Guevara (2012) the effectiveness of crowdsourcing requires a simultaneous existence of precisely those three key aspects. This means that crowdsourcing and the tools connected with it must be built taking into consideration concrete tasks and needs. Only such a configuration may contribute to obtaining and making use of the benefits of crowdsourcing, while at the same time eliminating potential barriers or obstacles (Louis, 2013; Cullina, Conboy \& Morgan, 2015).

In line with the above, it is assumed that crowdsourcing is effective when the organization has attained the assumed goal. However, it is dependent on intermediate goals, which draw closer to the intended effect - i.e. specific decisions. Making these endeavours by the organizations is dependent on seeing the benefits which may be gained thanks to crowdsourcing, among others: access to talents, external knowledge (Burger-Helmchen \& Penin, 2010), valuable information (Greengard, 2011), resources (Brabham, 2008), skills and experience (Oliveira, Ramos \& Santos, 2010), mobilization (Zhao \& Zhu, 2012), and competences (Chanal \& Caron-Fasan, 2008). It may be used for organizational learning, openness of the organization to new external knowledge (Chesbrough \& Crowther, 2006; Chesbrough, 2010; Huston \& Sakkab, 2006; Feller et al., 2012; Majchrzak \& Malhotra, 2013), creating open innovations (Brabham, 2008; Burger-Helmchen \& Penin, 2010), building competitive advantage (Leimeister \& Zogaj, 2013), improving business processes (Burger-Helmchen \& Penin, 2010; Brabham, 2008; Balamurugan \& Roy, 2013), optimising costs of the organization's activity or business models (Garrigos-Simon et al., 2014). The possibility of building crowd capital is emphasised (Prpić \& Shukla, 2013; Lenart-Gansiniec, 2016).

In relation to the fact that the current literature conceptualizations related to measuring crowdsourcing do not ensure a full picture of the whole phenomenon (Geiger, Rosemann \& Fielt, 2011) - an own, original evaluation tool has been proposed. Considering the fact that crowdsourcing is a complex concept, a two-stage evaluation of crowdsourcing in public organizations may be proposed. The fact that the category of crowdsourcing may be presented in the form of indicators, which enable measuring the level of a given category, was taken into account. One should however bear in mind that not all features can be expressed in a quantitative way, especially when a given notion refers to a real value, which describes real phenomena (Zieleniewski, 1966). The assessment of effectiveness is conditioned by the goal's formula itself. If the goal has measurable features then the organization has the capability of evaluating the effectiveness of its realization. 
The first stage of evaluating the effectiveness of crowdsourcing is based on a "binary" way of evaluating in the sense of a "yes" or "no" answer to the question whether the goal has been attained. This does not, of course, exclude the possibility of graduating the level of realization of each particular goal. In case of the criterion it is achieving the goal alone (Table 3), while expressing crowdsourcing in a holistic way, i.e. the level of the initiator (organizational), crowd (virtual community), and technology (crowdsourcing platform). The phases of crowdsourcing have also been considered.

In the proposal simple measures were developed, which to a large part are of a quantitative and qualitative nature. What is important is that the choice of proper measures is a derivative of the goals that the organization wants to achieve by means of crowdsourcing - and that they should also cover those aspects as they are a priority to the organization. It should, however, be remembered that some indicators work out only in the case of specific subjects of crowdsourcing - the measurement should take into account their specifics. This is particularly important in the case of public organizations. Examples prove that not every crowdsourcing initiative ends with a success. Some of them do not arouse the interest of the virtual community (www. dobrepomysły.krosno.pl), whereas others receive a great deal of attention (www.otwartawarszawa.pl). Moreover, the decisions about purchasing or hiring a crowdsourcing platform by public organizations is connected with utilizing public funds - therefore, it is important to evaluate the effectiveness of the whole action.

Table 3. An original tool for evaluating crowdsourcing effectiveness - audit questions

\begin{tabular}{|c|c|c|c|}
\hline $\begin{array}{l}\text { Crowdsourcing } \\
\text { phases }\end{array}$ & Organizational level & Technological level & Virtual community leve \\
\hline 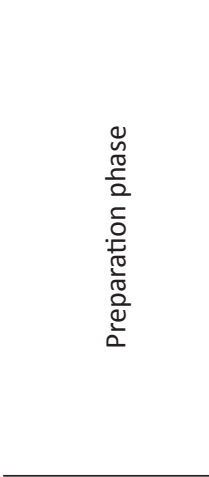 & $\begin{array}{l}\text { Has the goal of } \\
\text { crowdsourcing been } \\
\text { defined? } \\
\text { Has the choice of } \\
\text { crowdsourcing type } \\
\text { been made? } \\
\text { Has the task directed } \\
\text { to the crowd been } \\
\text { selected? } \\
\text { Have expectations } \\
\text { towards the virtual } \\
\text { community been } \\
\text { formulated? }\end{array}$ & $\begin{array}{l}\text { Will the organization } \\
\text { use the existing } \\
\text { crowdsourcing platform? }\end{array}$ & $\begin{array}{l}\text { Has the crowdsourcing } \\
\text { target group been } \\
\text { defined (sex, age, } \\
\text { education, place of } \\
\text { residence)? }\end{array}$ \\
\hline
\end{tabular}




\begin{tabular}{|c|c|c|c|}
\hline $\begin{array}{l}\text { Crowdsourcing } \\
\text { phases }\end{array}$ & Organizational level & Technological level & Virtual community level \\
\hline 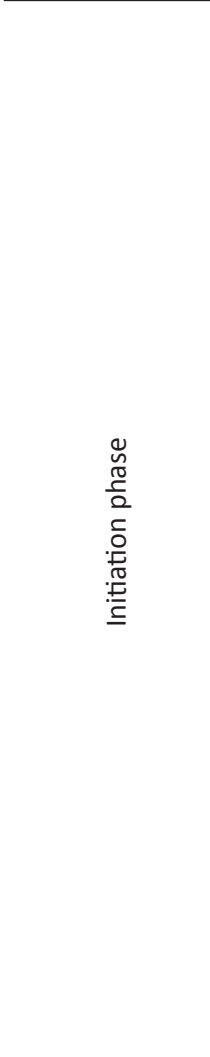 & $\begin{array}{l}\text { Has an open call } \\
\text { inviting the community } \\
\text { to collaborate been } \\
\text { prepared? } \\
\text { Have the tasks and } \\
\text { problems been defined } \\
\text { properly? } \\
\text { Has a schedule of } \\
\text { crowdsourcing actions } \\
\text { been developed? } \\
\text { Has a promotional } \\
\text { campaign for the } \\
\text { project been planned? } \\
\text { Have the regulations of } \\
\text { selecting a project for } \\
\text { implementation been } \\
\text { developed? } \\
\text { Has a system of } \\
\text { evaluating the quality } \\
\text { of submitted ideas } \\
\text { been implemented? } \\
\text { Have prizes for the } \\
\text { best ideas been agreed } \\
\text { upon? } \\
\text { Have persons } \\
\text { responsible for entering } \\
\text { into interactions with } \\
\text { the virtual community } \\
\text { been appointed? }\end{array}$ & $\begin{array}{l}\text { Have procedures } \\
\text { related to protecting } \\
\text { the organization's } \\
\text { intellectual property } \\
\text { been implemented? } \\
\text { Has a way of } \\
\text { communication between } \\
\text { the organization and the } \\
\text { virtual community been } \\
\text { developed? } \\
\text { Is the platform easy to } \\
\text { operate? } \\
\text { Is it possible to add } \\
\text { comments? } \\
\text { Is the platform } \\
\text { accessible by means } \\
\text { of various devices and } \\
\text { operating systems? }\end{array}$ & $\begin{array}{l}\text { Has a system of } \\
\text { motivating employees } \\
\text { to make use of the } \\
\text { knowledge been } \\
\text { developed? }\end{array}$ \\
\hline 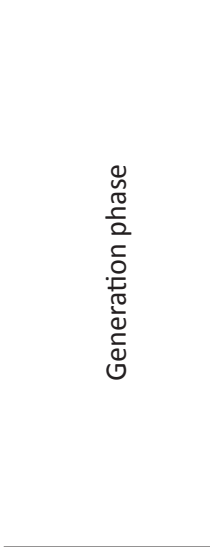 & $\begin{array}{l}\text { Is the idea inflow } \\
\text { process continuously } \\
\text { monitored? } \\
\text { Are the submitted ideas } \\
\text { coordinated? } \\
\text { Does the organization } \\
\text { communicated with the } \\
\text { virtual community? } \\
\text { Does the organization } \\
\text { inspire the virtual } \\
\text { community to take } \\
\text { action? } \\
\text { Does the organization } \\
\text { verify the received } \\
\text { solutions? }\end{array}$ & $\begin{array}{l}\text { Are the submitted ideas } \\
\text { categorised? } \\
\text { Has the range been } \\
\text { measured (platform's } \\
\text { range, number of hits, } \\
\text { participation of the } \\
\text { target group, number of } \\
\text { clicks, number of visits } \\
\text { at the site)? }\end{array}$ & $\begin{array}{l}\text { Is the virtual community } \\
\text { encouraged do exchange } \\
\text { opinions? } \\
\text { Is the virtual community } \\
\text { encouraged to submit } \\
\text { ideas? } \\
\text { Do the members of the } \\
\text { virtual community enter } \\
\text { into interactions with } \\
\text { other users? } \\
\text { Do the members of } \\
\text { the virtual community } \\
\text { possess appropriate } \\
\text { competences? }\end{array}$ \\
\hline
\end{tabular}




\begin{tabular}{|c|c|c|c|}
\hline $\begin{array}{l}\text { Crowdsourcing } \\
\text { phases }\end{array}$ & Organizational level & Technological level & Virtual community level \\
\hline 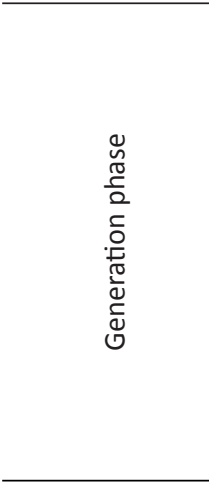 & & & $\begin{array}{l}\text { Do the members of } \\
\text { the virtual community } \\
\text { collaborate with each } \\
\text { other? } \\
\text { Do the members of } \\
\text { the virtual community } \\
\text { share knowledge among } \\
\text { themselves? } \\
\text { Has the measurement of } \\
\text { the confidence towards } \\
\text { the organization of } \\
\text { the virtual community } \\
\text { members been made? }\end{array}$ \\
\hline 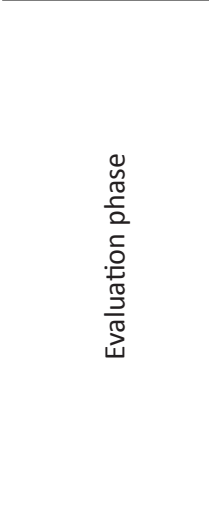 & $\begin{array}{l}\text { Have the submitted } \\
\text { solutions been verified? } \\
\text { Are the submitted } \\
\text { ideas conforming to the } \\
\text { assumed criteria? } \\
\text { Has the best solution } \\
\text { been selected? }\end{array}$ & $\begin{array}{l}\text { Has involvement been } \\
\text { measured (number } \\
\text { of registered users, } \\
\text { number of entries } \\
\text { onto the platform, } \\
\text { number of entries/ } \\
\text { comments, number of } \\
\text { clicks, number of added } \\
\text { ideas, number of users, } \\
\text { number of votes given } \\
\text { to entries, number } \\
\text { of themes/posts on } \\
\text { the forum, number of } \\
\text { displays of entries)? }\end{array}$ & $\begin{array}{l}\text { Have the member of } \\
\text { the virtual community } \\
\text { been informed about } \\
\text { the selection of the best } \\
\text { solution? }\end{array}$ \\
\hline 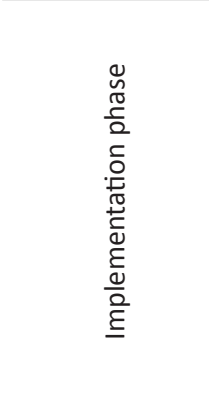 & $\begin{array}{l}\text { Has the decision on } \\
\text { further collaboration } \\
\text { with the virtual } \\
\text { community been } \\
\text { made? }\end{array}$ & $\begin{array}{l}\text { Has an evaluation of the } \\
\text { crowdsourcing platform } \\
\text { usefulness been } \\
\text { conducted? } \\
\text { Has a decision about the } \\
\text { future of the possessed } \\
\text { platform been made } \\
\text { (need to modify/ } \\
\text { change the platform / } \\
\text { continuation of work on } \\
\text { a chosen platform)? }\end{array}$ & $\begin{array}{l}\text { Has the virtual } \\
\text { community been } \\
\text { informed about } \\
\text { the scope of idea } \\
\text { implementation? }\end{array}$ \\
\hline
\end{tabular}

The second stage of the proposed analysis of crowdsourcing effectiveness consists of a point evaluation of the conditions of this collaboration using a scale from 1 to 7 ( 1 - "I absolutely do not agree", 7 - "I absolutely agree"). Two reasons justify the introduction of a 7-point Likert's scale. Firstly, based on a systematic literature review (Lenart-Gansiniec, 2017), it may be concluded that it is the most popular scale used for crowdsourcing measurement. Secondly, this scale enables one to increase measurement accuracy and to 
ensure greater transparency and reliability of the evaluation. This stage is a complement to the indicators obtained previously. Based on literature research (Buettner, 2015) the following conditions of crowdsourcing were defined, which should be evaluated qualitatively - its multidimensionality has been taken into account in this respect:

- organizational level: innovative culture and organizational structure, a positive organizational climate, proactive leadership, openness of the organization to novelties and changes, an appropriate level of employees' motivation, innovation strategy, coherence of the vision and strategy with the crowd's aspirations, appropriately shaped relations with external entities, the organization's trust towards virtual communities;

- technological level: abilities to capture open and hidden knowledge of the virtual, compatibility and functionality of the crowdsourcing platform;

- virtual community level: a readiness to share knowledge, the level of external and internal motivation, and an inclination to trust.

The proposed quantitative and qualitative approach in the measurement of crowdsourcing effectiveness may contribute to a comprehensive and reliable diagnosis. The quantitative and qualitative approach is recommended in Brabham's (2014) literary works.

Nonetheless, it should be remembered that the measurement of crowdsourcing may end with a failure - taking into account the barriers and obstacles which contribute to the organization not being able to achieve the intended crowdsourcing goal. One may include in the barriers at the organizational level the following: communication problems, reluctance to acquire others' knowledge, a bureaucratic organizational structure, reluctance to crowdsourcing, lack of trust towards virtual communities, difficulties connected with intellectual property protection, process barriers included in administrative processes, fear of changing the business model, and an organizational culture which is closed to innovation. The obstacles at the level of the virtual community are among others the following: a lack of trust towards the organization, a lack of motivation, and a lack of sufficient knowledge or experience. From the process perspective an important role is played by unreliability or an improperly selected crowdsourcing platform, i.e. inadequate and unsuitable for the contextual, relational, and situational needs of the organization (Erickson et al., 2012). Among the potential dangers, one may point to the risk of obtaining low quality ideas developed by the virtual community and reluctance of the crowd towards interactions from crowdsourcing. To minimise them, the key importance is the proper selection of the target group - this will enable the realization of the expectations of both parties, i.e. the organization will obtain useful knowledge, whereas the 
virtual community will get a task that is interesting to it. In addition, attention should be paid to a suitable motivation system for the crowd and employees, an effectiveness communication between the employees, agreeing a concrete goal and the benefits to be obtained by the organization, building of trust and implementing procedures for securing protection of the organization's intellectual property.

\section{CONCLUSIONS}

The presented deliberations on the measurement of crowdsourcing enable the formulation of the following conclusions:

Measuring crowdsourcing enables making an ascertainment connected with the degree of realization or rather approaching the goal assumed by the organization. This enables the faster achievement of the benefits of crowdsourcing assumed by it. Nonetheless, it is only possible owing to a multi-level approach to crowdsourcing.

The measurement of crowdsourcing is necessary in public organizations. It results from the necessity and pressure put on public organizations, which results from the growing expectations of the citizens. And so, in order that the organization may meet the dynamically changing requirements of its surroundings, it has to evaluate the actions taken by it. It seems that it is necessary to develop a model of assessing its success and introducing mechanisms enabling its permanent monitoring and guaranteeing the expected level. In the author's opinion an attempt should be made to create a full model evaluation of crowdsourcing undertaken by public organizations, taking into account as precisely as possible the nature and complexity of crowdsourcing and the specificity of public organizations.

The measurement of crowdsourcing causes many problems, since so far no tool has been developed that would make it possible. By the same token, it has become necessary to develop an original tool. The results of crowdsourcing may be measured by means of quantitative and qualitative indicators. The condition for selecting appropriate measures is first indicating the goals for which crowdsourcing is to be used.

\section{Acknowledgments}

This project was financed from the funds provided by the National Science Centre, Poland awarded on the basis of decision number DEC-2016/21/D/ HS4/01791. 


\section{References}

Alonso, O., \& Mizzaro, S. (2012). Using crowdsourcing for TREC relevance assessment. Information Processing and Management, 48(6), 10531066.

Balamurugan, Ch., \& Roy, S. (2013). Human computer interaction paradigm for business process task crowdsourcing. Proceedings of the 11th Asia Pacific Conference on Computer Human Interaction (pp. 264-273). Bangalore, India - September 24- 27.

Bayus, B. (2013). Crowdsourcing new product ideas over time: An analysis of the Dell Ideastorm community. Management Science, 59, 226-244.

Bielski, M. (2002). Podstawy Teorii Organizacji i Zarzqdzania. Warszawa: C. H. Beck.

Brabham, D.C. (2008). Crowdsourcing as a model for problem solving: An introduction and cases, convergence. The International Journal of Research into New Media Technologies, 14(1), 75-90.

Brabham, D.C. (2013). Crowdsourcing: A model for leveraging online communities. In A.A. Delwiche \& J.J. Henderson (Eds.), The Participatory Cultures (pp. 120-129). New York: Routledge.

Buettner, R. (2015). A systematic literature review of crowdsourcing research from a human resource management perspective. Paper presented at the 48th Hawaii International Conference on System Sciences, Kauai, HI.

Burger-Helmchen, T., \& Pénin, J. (2010). Crowdsourcing d'Activités Inventives: Une Analyse Critique par les Théories de l'Entreprise. Conférence GECSO. Strasbourg.

Cabiddu, F., Lui, T.-W., \& Piccoli, G. (2013). Managing value co-creation in the tourism industry. Annals of Tourism Research, 42, 86-107.

Cameron, K.S., \& Whetten, D.A. (1983). Organizational: A Comparison of Multiple Models. New York: Academic Press.

Chanal, V., \& Caron, M.L. (2008). How to invent a new business model based on crowdsourcing: The Crowdspirit ${ }^{\circledR}$ case. EURAM Conference, Slovenia.

Chandler, D., \& Kapelner, A. (2010). Breakingmonotonywithmeaning:Motivation incrowdsourcingmarkets.JournalofEconomicBehavior\&Organization,90, 123-133.

Chesbrough, H. (2010). Business model innovation: Opportunities and barriers. Long Range Planning, 43(2-3), 354-363.

Chesbrough, H., \& Crowther, A.K. (2006). Beyond high tech: Early adopters of open innovation in other industries. R\&D Management, 36(3), 229-236.

Cullina, E., Conboy, K., \& Morgan, L. (2015). Measuring the crowd A preliminary taxonomy of crowdsourcing metrics. Proceedings of The International Symposium on Open Collaboration, OpenSym.

Erickson, L.B., Petrick, I., \& Trauth, E.M. (2012). Organizational uses of the crowd: Developing a framework for the study of enterprisecrowdsourcing. Proceedings of ACM SIGMIS Computers and People Research Conference. Milwaukee. 
Estelles Arolas, E., \& González-Ladrón-De-Guevara, F. (2012). Towards an integrated crowdsourcing definition. Journal of Information Science, $32(2), 1-14$.

Feller, J., Finnegan, P., Hayes, J., \& O’Reilly, P. (2012). Orchestrating sustainable crowdsourcing: A characterization of solver brokerages. Journal of Strategic Information Systems, 21(3), 216-232.

Frączkiewicz-Wronka, A. (Ed.). (2013). Efektywność zarządzania organizacjami publicznymi i jej pomiar. Studia Ekonomiczne. Zeszyty Naukowe Wydziałowe Uniwersytetu Ekonomicznego w Katowicach, 168, 9.

Garrigos-Simon, F.J., Narangajavana, Y., \& Galdón-Salvador, J.L. (2014). Crowdsourcing as a competitive advantage for new business models. In I. Gil-Pechuán, D. Palacios-Marqués, M. Peris Peris-Ortiz, E. Vendrell \& C. Ferri-Ramirez (Eds.), Strategies in E-Business. Positioning and Social Networking in Online Markets. New York: Springer.

Gassmann, O. (2012). Crowdsourcing - Innovationsmanagement mit Schwarmintelligenz. München: Verlag.

Gassmann, O., Daiber, M., \& Muhdi, L. (2010). Der Crowdsourcing prozess. In Crowdsourcing - Innovationsmanagement mit Schwarmintelligenz (pp. 21.44). München: Hanser.

Geiger, D., Rosemann, M., \& Fielt, E. (2011). Crowdsourcing information systems - a systems theory perspective. Proceedings of the 22nd Australasian Conference on Information Systems.

Greengard, S. (2011). Following the crowd. Communications of the ACM, 2(54), 20-22.

Hossain, M., \& Kauranen, I. (2015). Crowdsourcing: A comprehensive literature review. Strategic Outsourcing: An International Journal, 1(8), $2-22$.

Howe, J. (2006). The rise of crowdsourcing. Wired, 14(6), 1-4.

Hudson-Smith, A., Batty, M., Crooks, A., \& Milton, R. (2009). Mapping for the masses: Accessing Web 2.0 through crowdsourcing. Social Science Computer Review, 27(4), 524-553.

Huston, L., \& Sakkab, N. (2006). Connect and develop -inside P\&G's new model for innovation. Harvard Business Review, 84(3), 58-66.

Kosinski, M., Bachrach, Y., Kasneci, G., Van-Gael, J., \& Graepel, T. (2012). Crowd IQ: Measuring the intelligence of crowdsourcing platforms. Proceedings of the 3rd Annual ACM Web Science Conference ACM.

Kotarbiński, T. (1969). Traktat o Dobrej Robocie. Wrocław: Zakład Narodowy im. Ossolińskich.

Krawiec, W. (2014). Crowdsourcing - czynniki motywujące tłum do działania. Marketing i Rynek, 4, 14-21.

Krawiec, W. (2014). Skuteczność projektów crowdsourcingowych planowanie oraz możliwość pomiaru. Marketing i Rynek, 4, 60-66.

Leimeister, J.M., Huber, M., Bretschneider, U., \& Krcmar, H. (2009). Leveraging crowdsourcing: Activation-supporting components for IT-based ideas 
competition. Journal of Management Information Systems, 26(1), 197224.

Leimeister, J. M., \& Zogaj, S. (2013). Neue Arbeitsorganization durch Crowdsourcing: Eine Literaturstudie. Düsseldorf: Hans Böckler Stiftung.

Lenart-Gansiniec, R. (2017). Crowdsourcing - systematyczny przegląd literatury. Przeglad Organizacji, 3, 25-34.

Lenart-Gansiniec, R. (2016). Crowd capital - conceptualization attempt. International Journal of Contemporary Management, 15(2). 29-57.

Uppström, E., \& Lönn, C.M. (2013). The promise of a crowd. 19th Americas Conference on Information Systems (AMCIS). Chicago.

Louis, C.A. (2013). Organizational perspectives of open innovation in government. iConference Proceedings.

Majchrzak, A., \& Malhotra, A. (2013). Towards an information systems perspective and research agenda on crowdsourcing for innovation. The Journal of Strategic Information Systems, 22(4), 257-268.

Oliveira, F., Ramos, I., \& Santos, L. (2010). Definition of a crowdsourcing Innovation Service for the European SMEs. In F. Daniel \& F.M. Facca (Eds.), Current Trends in Web Engineering. Berlin/Heidelberg: Springer.

Pszczołowski, T. (1978). Mała Encyklopedia Prakseologii i Teorii Organizacji. Wrocław - Warszawa - Kraków - Gdańsk: Zakład Narodowy imienia Ossolińskich.

Quinn, A.J., \& Bederson, B.B. (2011). Human computation: A survey and taxonomy of a growing field. Proceedings of the SIGCHI Conference on Human Factors in Computing Systems. New York, USA.

Rosen, P.A. (2011). Crowdsourcing lessons for organizations. Journal of Decision Systems, 20(3), 309-324.

Rouse, A.C. (2010). A preliminary taxonomy of crowdsourcing. Australian Conference on Information System (ACIS). Brisbane.

Prpić, J., \& Shukla, P. (2013). The theory of crowd capital. Proceedings of the Hawaii International Conference on System Sciences 46.

Skrzypek, E. (Ed.) (2000). Efektywność Systemów Zarzq̨dzania. Lublin: UMCS. Skurzyńska-Sikora, U. (2008). Poprawa efektywności organizacji przy wykorzystaniu modelu PEMM. Organizacja i Zarzqdzanie, 3, 513-523.

Sloane, P. (2011). A Guide to Open Innovation and Crowdsourcing: Advice from Leading Experts. UK: Kogan Page Publishers.

Surowiecki, J. (2004). The Wisdom of Crowds. New York: W. W. Norton \& Company, Inc.

Vukovic, M. (2009). Crowdsourcing for Enterprises. SERVICES '09 Proceed of the 2009 Congress on Services - I. Los Angeles, CA.

Whitla, P. (2009). Crowdsourcing and its application in marketing activities. Contemporary Management Research, 1(5), 15-28.

Yang, J., Adamic, L.A., \& Ackerman, M.S. (2008). Crowdsourcing and knowledge sharing: Strategic user behavior on tasks. Paper presented at Proceedings of the 9th ACM Conference on Electronic Commerce. Chicago. 
Zhao, X., \& Zhu, Q. (2012). Evaluation on crowdsourcing research: Current status and future direction. Information Systems Frontier, 16(3), 417434.

Zieleniewski, J. (1966). Efektywność Badań Naukowych. Pracownia Ogólnych Problemów Organizacji Pracy Polskiej Akademii Nauk. Warszawa: PWN.

\begin{abstract}
Polish)
Współcześnie obserwuje się rosnqce zainteresowanie organizacji crowdfundingiem, $w$ tym również w sferze publicznej. Umożliwia to zdobywanie wiedzy zlokalizowanej w społecznościach wirtualnych. Jednak pomimo wielu korzyści, inicjatywy crowdsourcingowe często kończq się niepowodzeniem. W zwiqzku z tym uznaje się potrzebę ich oceny. Niemniej jednak $w$ literaturze przedmiotu można zaobserwować niedobór kryteriów i metod oceny crowdsourcingu. Istniejqce propozycje nie zapewniajq kompleksowego obrazu crowdsourcingu i nie uwzględniajq jego wielowymiarowości. Celem tego artykułu jest przedstawienie sposobów oceny crowdsourcingu oraz oryginalnej propozycji listy wskaźników, które mogq być wykorzystane do oceny crowdsourcingu w organizacjach publicznych. W artykule przedstawiono pierwotnq propozycję działań, na podstawie której można ocenić stopień realizacji przyjętych zadań i określić poziom uzyskanych wyników rowdsourcingowych. Przeprowadzone badania pozwoliły uznać, że możliwe jest mierzenie wyników crowdsourcingowych za pomocq wskaźników ilościowych i jakościowych. Warunkiem wyboru odpowiednich środków jest przede wszystkim wskazanie celów, dla których należy wykorzystać crowdsourcing.
\end{abstract}

Słowa kluczowe: crowdsourcing, efektywność, pomiar, organizacje publiczne.

\title{
Biographical note
}

Regina Lenart-Gansiniec - Assistant Professor at Jagiellonian University, Institute of Public Affairs. An expert in open innovation, knowledge management, clusters and public management of the Ministry of Economic Development (Poland) and Ministry of Economy (Poland). Research interests include open innovation, crowdsourcing, knowledge management, and organizational learning in public organizations. An author of publications on knowledge management, crowdsourcing, open innovation who has participated in several research projects. 



\title{
Relationships Between Trust And Collaborative Culture In The Context Of Tacit Knowledge Sharing
}

\section{Wioleta Kucharska ${ }^{1}$}

\begin{abstract}
The literature review presents a lot of theoretical and empirical evidence that trust affects collaborative culture. The opposite also proves to be true: collaborative culture influences trust. The main hypothesis presented in this paper says that both these factors are strongly correlated and modify each other. This study examines the mutual relationship of the said variables in the context of tacit knowledge sharing based on research conducted among 514 Polish professionals performing different functions, and having various experience in managing projects, in the construction industry. The results obtained in the course of the study indicate that there is not only a strong correlation between trust and collaborative culture but both of them have a strong influence on tacit knowledge sharing. The main managerial implication of the study is the importance of stimulating the growth of both collaborative culture and trust. receiving a strong synergy effect will make it possible to leverage tacit knowledge sharing as an agent contributing to a company's performance.

Keywords: trust, tacit knowledge sharing, collaborative culture, project management.
\end{abstract}

\section{INTRODUCTION}

Nowadays, in the network economy, conducting a successful business does not only require a collaboration of individuals but its more advanced form - co-creation. As Becket and Jones (2012) noticed, "as a result, there is now increased emphasis on trust and the important role it plays in ensuring collaboration success." Orchard, Curran, and Kabene (2005) point out that creating a collaborative culture based on a relationship of interdependence, built on respect, trust and understanding, can be beneficial for the final performance of a business. Based on the literature review, we can find a lot of

1 Wioleta Kucharska, Ph.D., Assistant Professor, Marketing Department, Management and Economics Faculty, Gdańsk University of Technology, Narutowicza 11/12 street, 80-233 Gdańsk, e-mail: wkucharska@zie.pg.gda.pl. 
theoretical and empirical evidence that trust affects collaborative culture and that collaborative culture influences trust. Although trust and collaboration often coexist, the two concepts differ markedly (Lefebvre \& Shiba, 2005).

Trust is understood as "the confidence that the reciprocal exchange between two parties will be met with a positive outcome for both" (Lee, Gillespie, Mann \& Wearing, 2010). Perez Lopez, Peon, and Ordas (2004), as well as Barczak, Lassk, and Mulki (2010) define collaborative culture as a "team's shared values and beliefs about the organizations' support for adaptability, open communication, and encouragement of respect, teamwork, risk-taking and diversity." Trust is built on the platform of having information about others, prior ties of working together, standards of cooperation, and sanctions for all who might break norms of behavior. Having an incentive is a necessary, but not an adequate basis for having trust (Harris \& Lyon, 2013).

"Culture has been viewed as an influencing element that impacts the morale of an employee, his motivation and willingness; the level of productivity and effectiveness; the quality of work; innovation and creativity; and the attitude of employees in the workplace" (Campbell, Stonehouse \& Houston, 1999). Collectivism and individualism, as dimensions of culture, represent sets of individuals' beliefs and values concerning the independence from and interdependence among other team members (Alavi \& McCormick, 2007). Furthermore, people high in collectivism orientation tend to put aside their own self-interest in deference to the interest of their group. Conversely, people low in collectivism (i.e., with a more individualistic orientation) tend to put forth and promote their own welfare over the interests of their group (Hofstede, 2001). According to Gray (1989), collaboration is "a process through which parties who see different aspects of a problem can constructively explore their differences and search for solutions that go beyond their own limited vision of what is possible." A collaborative culture reduces competition among employees and increases their willingness to share critical information (Szulanski, 1996). A culture of collaboration and mutual accountability provides an opportunity to end the blame-game cycle, as claimed by Wallace and Mello (2015). In their opinion, collaboration facilitates a proactive process which allows for the creation of shared goals and the development of mutual tasks, and permits more rapid identification of problems, creating a meaningful sense of organizational teamwork. Moreover, they claim that collaborative culture is a culture that, in today's world, businesses cannot afford to live without.

Sharing knowledge by co-workers is essential for organizations. Open sharing of relevant knowledge has the potential to lower costs and optimize processes. The lack of sharing may harm organizations and even render their processes ineffective (Rutten, Blaas-Franken \& Martin, 2016). Polanyi (1966) 
was among the first to classify knowledge as explicit and tacit. Over time, this classification was adopted by others. As opposed to explicit, tacit knowledge is absolutely novel and, for this reason, beneficial for organizations. This form of knowledge is peculiar; it is created and cumulated in a human's mind and, being an intangible asset, it is closely associated to social capital. Intangible assets become increasingly likely to decide on the competitive advantages of companies. They are not easily noticeable and are hard to measure; however, their indirect influence often proves to play a crucial role in value creation. A lot of studies have been dedicated to the general idea of explicit knowledge sharing, but only a few focus on tacit knowledge (Chow, 2012; Kucharska, 2016; Rutten et al., 2016).

Change is a permanent condition for businesses nowadays. In order to implement change successfully, companies run projects in such a way as to achieve the results they desire using the resources they have assigned to a given task (Portny, 2010). A project is an autonomous organization connected to a parent organization (Artto, Kujala, Dietrich \& Martinsuo, 2008). It is a series of tasks with a start and end date, specific goals and conditions, defined responsibilities, a budget, and multiple parties involved. Every project is unique in nature and does not involve any repetitive processes (Yang, 2012). Projects require the close cooperation of all their members.

The first goal of the study is to look at the mutual influence of collaborative culture and trust in the context of tacit knowledge sharing. The second goal is to present the results of empirical research of the study, conducted among 514 Polish professionals with different functions and experience in managing projects in the construction industry, as evidence of this mutual relationship.

\section{CONCEPTUAL FRAMEWORK}

The literature review gives us a lot of theoretical and empirical evidence that trust affects collaborative culture and that collaborative culture influences trust. According to Barczak, Lassk, and Mulki (2010), as well as Park and Lee (2014), Trust has a strong influence on collaborative culture. Kottila and Rönni (2008) claim that collaboration is approached by focusing on communication and trust between the business actors. With respect to the idea of a collaborative network, Berasategi, Arana, and Castellano (2011) claim that "trust amongst all network agents is the cornerstone of collaboration, and therefore there is a demand to promote a collaboration culture based on fostering human relations."

Likewise, Pishdad-Bozorgi and Beliveau (2016) point out the fact that trust creates a collaborative environment. In the opinion of Fawcett, Jones, and Fawcett (2012), breakthrough trust is the catalyst to collaborative innovation. 
Chen, Lin, and Yen (2014) examined that inter-organizational trust leads to better inter-organizational collaboration and knowledge sharing. Referring to online collaborative groups (OCG), Smith (2008) presents moderate trust models and assumes that trust provides conditions under which outcomes such as cooperation and high performance are likely to occur, but he assumes no direct relationship between them.

On the other hand, Lefebvre, and Shiba (2005) claim that collaboration fosters trust. They present a case study of the automotive industry as proof that collaboration can be transformed into trust. Establishing trust-building organizational routines (culture) requires a correct evaluation of a partner's collaborative capability and then measuring a partner performance, as suggested by Fawcett et al. (2012). According to Thomas, Zolin, and Hartman (2009), trust is shaped through collaboration and information sharing. Similarly, as Aramo-Immonen, Jaakkola, and Linna (2011) claim, creating a supportive behavioral base encourages the formation of trust. Wallace and Melo (2015) simply suggest that collaborative culture promotes trust; however, Taormina (2009) heartily points out that trust is an integral part of a collaborative culture.

In the opinion of Pishdad-Bozorgi and Beliveau (2016), true collaboration occurs when individuals trust and respect one another, know that their partners will not take advantage of them and that together they can develop better solutions and results than they would individually. Buvik and Rolfsen (2015), claim that relationships between task participants are built on mutual trust and collaboration. These two factors allow establishing an organizational culture which encourages knowledge sharing. The conclusion is that both these conditions must be met to achieve high performance. Kumar and Paddison (2000) argue also that both trust and collaboration reinforce each other. Based on the arguments above, the following hypothesis was formulated:

\section{H1: Trust and collaborative culture have a strong, positive correlation.}

Trust is an integral part of a collaborative culture and is found as one of the several antecedents of knowledge sharing behavior (Taormina, 2009). Trust is also an important predictor of knowledge sharing, as is claimed by Chen et al. (2014), and it is closely linked to information sharing and exchange (Bachmann \& Inkpen, 2011; Cai, Jun \& Yang, 2010; Cheikhrouhou, Pouly \& Madinabeitia, 2013; Msanjila \& Afsarmanesh 2009, 2011; Thimm \& Rasmussen, 2010). According to Young and Milton (2011), information is a source of knowledge. Research results by Park and Lee (2014) indicate that project team members share knowledge when they can trust one another and feel dependent. Ding, $\mathrm{Ng}$, and Li (2014) pointed out that trust strongly 
influences knowledge sharing in architectural design teams. Kucharska and Kowalczyk (2016) claim that trust has a positive impact on tacit knowledge sharing among project team members. Following the presented research, hypothesis 2 was formulated:

H2: Trust has a positive influence on tacit knowledge sharing.

Trust is needed to deal with the numerous business uncertainties involved. It is considered to have various important benefits for the practices of complex collaboration; it is supposed to facilitate cooperation, to render collaboration more robust, to boost performance and to make innovation possible (Klijn, Edelenbos \& Steijn, 2010; van Oortmerssen, van Woerkum \& Aarts, 2014). Brown, Gray, McHardy, and Taylor, (2015) present a theoretical framework which serves to establish a link between the employee trust and a company's performance. They claim that trust between employees in the workplace influences their behavior, which in turn affects a company's performance and a company's ability to achieve its goals, as was also pointed out by Gilbert and Li-Ping Tang (1998). Although trust is one of the key determinants of employee performance (Paliszkiewicz, 2011) it cannot be considered as a sum of individual performances (Bakotić, 2016). Business partners who reach collaborative trust share resources willingly to help create a greater, unique added value and improve business performance (Fawcett et al., 2012).

Referring to the construction industry, the research findings of PishdadBozorgi and Beliveau (2016) indicate that Integrated Project Delivery (IPD) as a form of close collaboration and trust have a bi-directional relationship. Results by Lau and Rowlinson (2009) and Buvik and Tvedt (2016) suggest that trust affects project commitment and also, directly and indirectly, team performance. Interventions to develop a high trust climate in project teams can thus contribute to improved project performance. Likewise, Mach and Baruch (2015) suggest that team orientation affects project performance mediated by trust. Based on all that was presented above, hypothesis 3 was formulated:

H3: Trust has a positive influence on project performance.

The collaborative orientation of organizational culture is an important implication for knowledge sharing (Greiner, Böhmann \& Krcmar, 2007). With reference to Khalil and Seleim (2010), individuals' knowledge should be shared in groups and teams, and this is crucial for the cultural support of knowledge sharing. For organizations, to gain an advantage of their knowledge-based resources, it is important to propagate a culture that will give preferential 
treatment to knowledge transfer activities (Barratt-Pugh, Kennett \& Bahn, 2013). Joint collaboration could result in rich and nuanced discourse that brings differing degrees of knowledge, insights, and understanding to all participants involved in the project (Rinehart \& Earl, 2016). The significant influence of Collaborative Culture on Knowledge Sharing has also been pointed out by Mueller (2014) and Arpaci and Baloglu (2016), and examined by Kucharska and Kowalczyk (2016). Based on the above, the hypothesis 4 was formulated:

H4: Collaborative culture has a positive impact on tacit knowledge sharing.

Inaam, Abderrahman, and Yasmina (2016) investigated a framework to characterize the financial and non-financial performance of an organization in terms of their collaborative practices. Chow's (2012) study presents that organizational collaborative culture has a direct influence on performance. The qualitative research conducted by Zuo, Zillante, Zhao, and Xia (2014), shows that projects with an integrative, cooperative, flexible, and people-oriented collaborative culture, performed much better than others in most of the dimensions of project outcomes, such as schedule, functionality, satisfaction from the process and relationships, environmental performance, commercial success, further business opportunities, and overall performance. Oyewobi, Abiola-Falemu, and Ibironke's (2016) studies prove the positive influence of organizational culture on high-quality project delivery in the construction industry. In relation to the presented research, hypothesis 5 was formulated:

\section{H5: Collaborative culture has a positive impact on project performance.}

Referring to studies of Hau, Kim, Lee, and Kim (2013) related to the impact of tacit knowledge sharing on explicit knowledge, which according to the research conducted by Park, and Lee (2014) and also Gemino, Reich, and Sauer (2015) has an effect on project performance, leads to the logical conclusion that analogically to general knowledge sharing the sharing of tacit knowledge has a positive impact on project performance. This train of thought is reflected in hypothesis no 6 . As was mentioned in the introduction section, very few researchers have examined tacit knowledge sharing and project performance creation. Studies of Chow (2012), Kucharska and Kowalczyk (2016) confirm that tacit knowledge sharing enhances project performance. Based on their study and all that was mentioned above, the hypothesis 6 as follows was formulated:

H6: Tacit knowledge sharing has a positive impact on project performance.

Figure 1 graphically presents the theoretical model. 


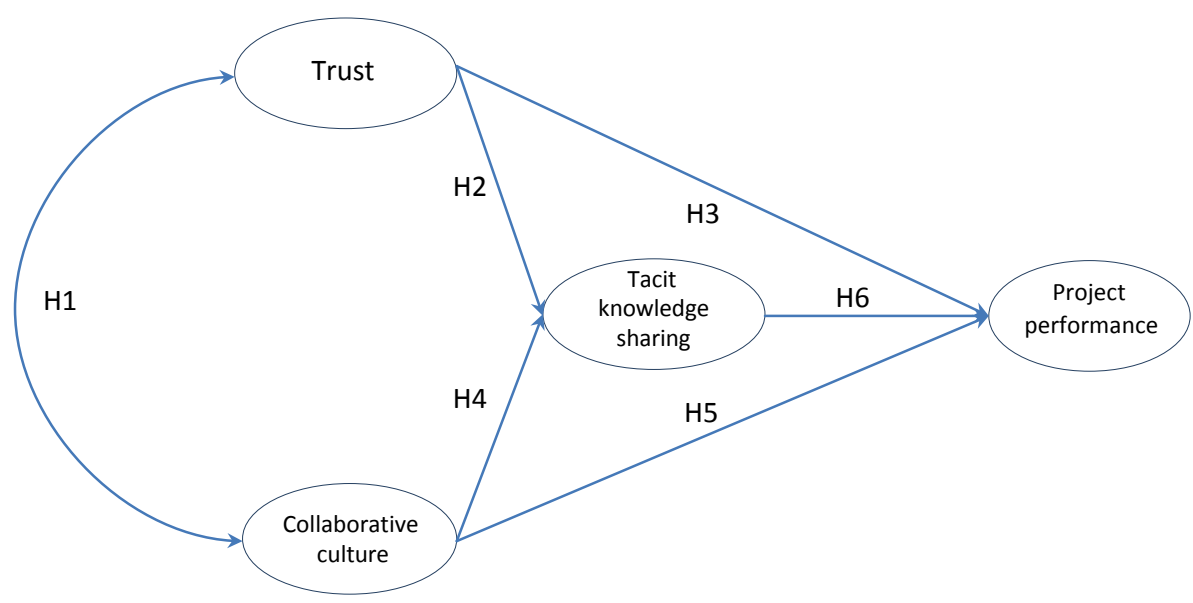

Figure 1. Conceptual framework

Source: author's own study based on Park \& Lee (2014), Arpaci \& Baloglu (2016), Chow (2012), Gemino, Reich \& Sauer (2015), Rinehart \& Earl (2016), Kucharska \& Kowalczyk (2016).

\section{METHODOLOGY}

The study was carried through a questionnaire completed by Polish professionals working in the construction industry. The respondents reacted to statements based on a 7-point Likert scale, which goes from 1 assigned as definitely NOT to 7 assigned as definitely YES. The statements created to match the measurement scales are presented in Table 2 . The questionnaire structure followed a path from general issues to detailed issues which required more precise answers. Thus, it started with a simple introduction explaining the aim and scope of the survey. At first, the qualifying questions strictly referred to the subject matter and regarded the participant's affiliation to any projects. Before running the full survey a preliminary study involving 32 respondents preceded it. The aim of this pilot study was to optimize the statements by ubiquity elimination. The final data gathering took place online, using the "snowball method", and started with managers who then recommended our study to their co-workers. The data were collected from February to April 2016. The sample size was 600 respondents, of which 514 cases were accepted for further analysis, after rejecting invalid forms. The sample comprised of $61 \%$ who were project managers, $16 \%$ team members, $21 \%$ team leaders, $1 \%$ from a steering committee, and $1 \%$ who were project sponsors, all with different experience levels. $98 \%$ of the respondents were 
male and $2 \%$ were female. The analysis was provided using the structural equation modelling method.

According to the theoretical model presented in Figure 1, a measurement model and, later, a structural Confirmatory Factor Analysis (CFA) model were run. Estimation was provided in the reference to a maximum likelihood method (ML). The model quality evaluation was conducted based, at first, on tests such as: Average of Variance Extracted (AVE), Composite Reliability (CR), Cronbach's Alpha, and next: Root Mean Square Error of Approximation (RMSEA), CMIN/DF, Comparative Fit Index (CFI) with the use of SPSS AMOS 23 software. Table 1 presents the model's goodness of fit test results.

Table 1. The assessment of the model's goodness of fit

\begin{tabular}{llllllllll}
\hline CMIN/DF & RMSEA & GFI & IFI & TLI & CFI & AGFI & AGFI/CFI & CR & AVE \\
3.52 & 0.078 & 0.938 & 0.97 & 0.96 & 0.97 & 0.900 & $0.92>0.9$ & $0.89<C R$ & $0.72<$ AVE \\
\hline
\end{tabular}

Source: author's own study developed with SPSS AMOS 23.

Based on the presented test results the CFA model may be assessed as well fit in relation to the gathered data. The reliability level 3.52 can be viewed as high, with the reference $\leq 5$ (Wheaton, 1977). The approximation average error (RMSEA) at 0.078 also meets the reference value below 0.08 according to Steiger and Lind (1980). Measurements of the goodness of fit came close to 1 (Bollen, 1986, 1989) and AGFI/CFI>0.9, which confirms the quality results. AVE (Average of Variance Extracted) is higher than 0.75 for all loadings. Hair, Anderson, Babin, and Black (2010) suggest that an AVE of 0.5 or higher indicates adequate convergence. Cronbach's Alpha test was used to confirm consistency of the constructs measurement model and the alpha coefficient is higher than 0.88 for all constructs which is correct (Francis, 2001; Robinson, Shaver \& Wrightsman, 1991). CR (Composite Reliability) is higher than 0.89 for all loadings, more than the required minimum 0.7 (Hair et al., 2010).

Table 2 presents more details connected with the used scales and their reliabilities, whereas Table 3 confirms discriminant validity (Fornell \& Lacker, 1981). The positive assessment of the model allows us to present the results. 
Table 2. Constructs and scales

\begin{tabular}{|c|c|c|c|}
\hline Construct & Scale & Adapted from & $\begin{array}{l}\text { CFA constructs } \\
\text { validity }\end{array}$ \\
\hline $\begin{array}{l}\text { Tacit } \\
\text { knowledge } \\
\text { sharing (TKS) }\end{array}$ & $\begin{array}{l}\text { I shared my experience } \\
\text { and know-how with team } \\
\text { members of the project } \\
\text { I extracted new knowledge } \\
\text { from the project team } \\
\text { members based on their } \\
\text { experience and know-how } \\
\text { that helped me follow up the } \\
\text { project } \\
\text { I extracted new knowledge } \\
\text { and know-how from experts } \\
\text { and functional co-workers in } \\
\text { my organization that helped } \\
\text { me follow up the project }\end{array}$ & $\begin{array}{l}\text { Gemino, Reich and } \\
\text { Sauer (2015); Park } \\
\text { and Lee (2014); } \\
\text { Hau et al. (2013) }\end{array}$ & $\begin{array}{l}\text { AVE }=0.75 \\
C R=0.90 \\
\text { Cronbach's } \\
\text { Alpha }=0.90\end{array}$ \\
\hline $\begin{array}{l}\text { Trust } \\
(\mathrm{T})\end{array}$ & $\begin{array}{l}\text { My partners helped me make } \\
\text { critical decisions } \\
\text { My partners could be trusted } \\
\text { completely } \\
\text { I have great confidence in my } \\
\text { partners. }\end{array}$ & $\begin{array}{l}\text { Park and Lee } \\
(2014)\end{array}$ & $\begin{array}{l}\text { AVE }=0.79 \\
C R=0.92 \\
\text { Cronbach's } \\
\text { Alpha }=0.92\end{array}$ \\
\hline $\begin{array}{l}\text { Collaborative } \\
\text { culture } \\
(\mathrm{K})\end{array}$ & $\begin{array}{l}\text { Problems were discussed } \\
\text { openly to avoid finding } \\
\text { culprits } \\
\text { Collaboration and co- } \\
\text { operation among the } \\
\text { different duties, teams and } \\
\text { departments was encouraged } \\
\text { In general, all teams and } \\
\text { departments are aware of } \\
\text { consumer satisfaction }\end{array}$ & $\begin{array}{l}\text { Perez Lopez, Peon } \\
\text { and Ordas (2004) }\end{array}$ & $\begin{array}{l}\text { AVE }=0.75 \\
C R=0.90 \\
\text { Cronbach's } \\
\text { Alpha }=0.90\end{array}$ \\
\hline $\begin{array}{l}\text { Project } \\
\text { performance } \\
\text { (PP) }\end{array}$ & $\begin{array}{l}\text { I was informed that the } \\
\text { Sponsor of the project was } \\
\text { satisfied with the project } \\
\text { results } \\
\text { I was informed that the } \\
\text { Sponsor of the project was } \\
\text { satisfied with the project } \\
\text { benefits } \\
\text { I received feedback that } \\
\text { the Sponsor of the project } \\
\text { assessed the project positively }\end{array}$ & $\begin{array}{l}\text { Gemino, Reich, } \\
\text { Sauer (2015), } \\
\text { Babbie (2013) }\end{array}$ & $\begin{array}{l}\text { AVE }=0.72 \\
\text { CR=0.89 } \\
\text { Cronbach's } \\
\text { Alpha }=0.88\end{array}$ \\
\hline
\end{tabular}


Table 3. Factor correlation matrix with square root of the AVE on the diagonal

\begin{tabular}{|c|c|c|c|c|c|c|c|}
\hline & AVE & CR & $\begin{array}{l}\text { Cronbach's } \\
\alpha\end{array}$ & K & $\mathbf{T}$ & TKS & PP \\
\hline $\bar{K}$ & 0.75 & 0.90 & 0.90 & 0.87 & & & \\
\hline $\mathrm{T}$ & 0.79 & 0.92 & 0.92 & 0.67 & 0.89 & & \\
\hline TKS & 0.75 & 0.90 & 0.90 & 0.71 & 0.71 & 0.87 & \\
\hline PP & 0.72 & 0.89 & 0.88 & 0.42 & 0.47 & 0.40 & 0.85 \\
\hline
\end{tabular}

Source: author's own study with the use of SPSS AMOS 23.

\section{ANALYSIS/STUDY}

The results point out that collaborative culture and trust are strongly correlated in the context of tacit knowledge sharing and that both these variables have a positive impact on project performance. Referring to path coefficients, the influence of trust on project performance is much stronger than on collaborative culture. Unlike the strong relationship between trust and collaborative culture, tacit knowledge sharing has no significant influence on project performance.

Figure 2 below is a graphical representation of the achieved results.

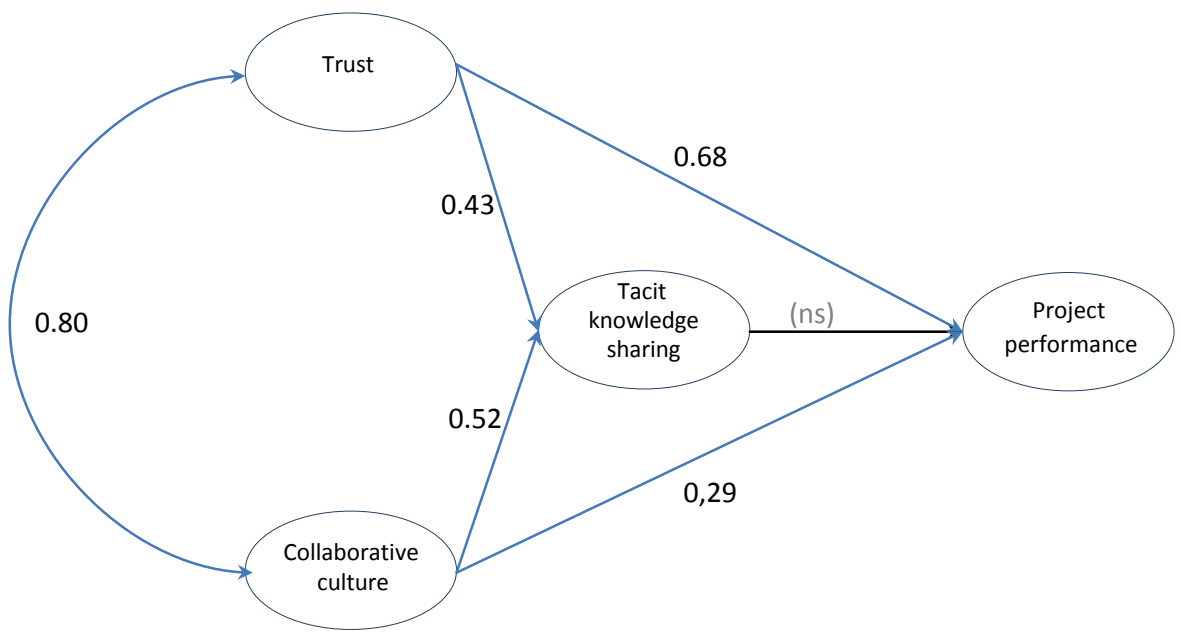

Note: CFA model p<0.001, RMSEA $=0.078$, Cronbach's Alpha $>0.88$, CR $>0.89$ AVE $>0.75$, estimation standardized, ML method, (ns) - not supported.

Figure 2. A graphical representation of achieved results. Source: author's own study with the use of SPSS AMOS 23 
Table 4 below presents a summary of the hypothesis verification referring to the theoretical model presented in Figure 1.

Table 4. Summary of the hypothesis verification

\begin{tabular}{|c|c|c|c|c|c|}
\hline \multicolumn{2}{|c|}{ Hypothesis } & \multirow{2}{*}{$\frac{\text { B }}{.802}$} & \multirow{2}{*}{$\begin{array}{l}\text { C.R } \\
10.76\end{array}$} & \multirow{2}{*}{$\begin{array}{l}\mathbf{p} \\
<0.001\end{array}$} & \multirow{2}{*}{$\begin{array}{l}\text { supported } \\
\text { YES }\end{array}$} \\
\hline $\mathrm{H} 1$ & $\begin{array}{l}\text { Trust and collaborative culture have } \\
\text { a strong, positive correlation. }\end{array}$ & & & & \\
\hline $\mathrm{H} 2$ & $\begin{array}{l}\text { Trust has a positive impact on tacit } \\
\text { knowledge sharing }\end{array}$ & .426 & 6.80 & $<0.001$ & YES \\
\hline H3 & $\begin{array}{l}\text { Trust has a positive impact on project } \\
\text { performance }\end{array}$ & .675 & 8.12 & $<0.001$ & YES \\
\hline $\mathrm{H} 4$ & $\begin{array}{l}\text { collaborative culture has a positive impact } \\
\text { on tacit knowledge sharing }\end{array}$ & .515 & 8.02 & $<0.001$ & YES \\
\hline H5 & $\begin{array}{l}\text { Collaborative culture has a positive impact } \\
\text { on project performance }\end{array}$ & .288 & 3.31 & $<0.001$ & YES \\
\hline H6 & $\begin{array}{l}\text { Tacit knowledge sharing has a positive } \\
\text { impact on project performance }\end{array}$ & -.128 & -1.28 & 0.200 & NO \\
\hline
\end{tabular}

Source: author's own study with the use of SPSS AMOS 23.

\section{DISCUSSION, CONCLUSIONS AND PRACTICAL IMPLICATIONS}

The studies presented in the article were carried out based on a sample including members of project organizations in the construction industry, predominantly men working as project managers (61\% respondents). Therefore, the conclusions of the study dominantly present project managers' point of view.

The aim of the paper was to study collaborative culture and trust in the context of tacit knowledge sharing and present empirical research as a proof of the correlation between the two factors. According to the results presented here and the literature of the subject matter, trust and collaboration between team members are the top concerns to the performance of construction projects. Collaborative relationships, complexity, the uncertainty of environmental conditions, and the pressures of time and budget (which are characteristic of construction projects) increase the need for trust and close cooperation between a project's participants.

The presented study highlights that these two "climate variables" are closely related. This fact leads to a conclusion that collaborative culture and trust co-exist and support each other. From a practical point of view, there is no sense to separate them. For the scientific purpose, it is interesting to measure differences and understand the relationship between these two constructs in different contexts. 
The study of trust and collaborative culture discussed in this work was conducted within the context of tacit knowledge sharing. Figure 2 and Table 4 show that tacit knowledge sharing has no significant influence on project performance. In light of the theoretical justification presented in the Introduction and Conceptual Framework sections, this comes as a surprise. Such an outcome might result from the specific mediatory character of the tacit knowledge sharing variable, more widely described by Kucharska and Dąbrowski (2016). It is worth highlighting that the discussed model is mostly composed of "climate variables" (Baumgartel, Reynolds \& Pathan, 1984), which are presented to be moderators for variables related to management effectiveness. Thus, the achieved results suggest that the tacit knowledge sharing variable is very sensitive and the possibility to observe its influence on project performance depends on other variables used to compose the model's structure. The tacit knowledge sharing variable remains to present itself as a research area worth exploring by scientists.

In relation to the theory presented in the introduction and the conceptual sections, the main new value, based on the presented study is empirical proof that collaborative culture and trust occur together and strongly support each other. Receiving a strong synergy effect as a result of the stimulation, their growth will make it possible to leverage tacit knowledge sharing as an agent contributing to a company's performance.

The study has some limitations which mainly concern the methodological issues. Firstly, the study was conducted on the data coming from the questionnaire survey collected among Polish professionals in the construction industry, where $98 \%$ of the respondents were male and only $2 \%$ were female. Therefore, in reference to the presented sample the conclusions of the study dominantly present a male project manager's point of view from only one industry. Thus, it will be interesting to conduct the same survey based on different industries where women are more widely represented. Results presented for other populations, especially non-European, could bring different conclusions. Secondly, this study has been investigating the structure of the model where antecedents such as trust and collaborative culture impact on tacit knowledge sharing and project performance as outcomes. Lewicki and Bunker (1996) suggest that trust is related to calculusbased and identification-based stages not only knowledge-based as was presented. It may well be that, in the case of other outcomes, the relation between trust and collaborative culture will be presented in a different light and lead to different conclusions. 


\section{References}

Alavi, S.B., \& McCormick, J. (2007). Measurement of vertical and horizontal idiocentrism and allocentrism. Small Group Research, 38(4), 556-564.

Aramo-Immonen, H., Jaakkola, H., \& Linna, P. (2011). Trust building in globalized software engineering: A cultural perspective. Journal of Global Information Technology Management, 14(4), 28-47.

Arpaci, I., \& Baloğlu, M. (2016). The impact of cultural collectivism on knowledge sharing among information technology majoring undergraduates. Computers in Human Behaviour, 56, 65-71.

Artto, K., Kujala, J., Dietrich, P., \& Martinsuo, M. (2008). What is project strategy? International Journal of Project Management, 26(1), 4-12.

Bachmann, R., \& Inkpen, A. C. (2011). Understanding institutional-based trust building processes in inter-organizational relationships. Organization Studies, 32(2), 281-301.

Bakotić, D. (2016). Relationship between job satisfaction and organisational performance. Ekonomska Istraživanja, 29(1), 118-130.

Barczak, G., Lassk, F, \& Mulki, J. (2010). Antecedents of team creativity: An examination of team emotional intelligence, team trust and collaborative culture. Creativity and Innovation Management, 19(4), 332-345.

Barratt-Pugh, L., Kennett, P., \& Bahn, S. (2013). Managing knowledge: The critical role of culture and ownership as a mediator of systems. International Journal of Knowledge Management, 9(2), 20-37.

Baumgartel, H. J., Reynolds, J. I., \& Pathan, R. Z. (1984). How personality and organisational climate variables moderate the effectiveness of management development programmes: A review and some recent research findings. Management \& Labour Studies, 9(1), 1-16.

Beckett, R. C., \& Jones, M. (2012). Collaborative network success and the variable nature of trust. Production Planning \& Control, 23(4), 240-251.

Berasategi, L., Arana, J., \& Castellano, E. (2011). A comprehensive framework for collaborative networked innovation. Production Planning \& Control, 22(5-6), 581-593.

Bollen, K.A. (1989). A new incremental fit index for general structural equation models. Sociological Methods \& Research, 17(3), 303-316.

Brown, S., Gray, D., McHardy, J., \& Taylor, K. (2015). Employee trust and workplace performance. Journal of Economic Behavior \& Organization, 116, 361-378.

Buvik, M.P., \& Rolfsen, M. (2015). Prior ties and trust development in project teams-A case study from the construction industry. International Journal of Project Management, 33(7), 1484-1494.

Buvik, M. P., \& Tvedt, S. D. (2016). The impact of commitment and climate strength on the relationship between trust and performance in crossfunctional project teams: A moderated mediation analysis. Team Performance Management, 22(3/4), 114-138. 
Cai, S., Jun, M., \& Yang, Z. (2010). Implementing supply chain information integration in china: The role of institutional forces and trust. Journal of Operations Management, 28(3), 257-268.

Campbell, D., Stonehouse, G., \& Houston, B. (1999). Business Strategy an Introduction, Butterworth-Heinemann, Oxford.

Cheikhrouhou, N., Pouly, M., \& Madinabeitia, G. (2013). Trust categories and their impacts on information exchange processes in vertical collaborative networked organisations. International Journal of Computer Integrated Manufacturing, 26(1-2), 87-100.

Chen, Y. H., Lin, T.P., \& Yen, D.C. (2014). How to facilitate inter-organizational knowledge sharing: The impact of trust. Information \& Management, 51(5), 568-578.

Chow, I. H. S. (2012). The role of social network and collaborative culture in knowledge sharing and performance relations. SAM Advanced Management Journal, 77(2), 24-33.

Ding, Z., Ng, F., \& Li, J. (2014). A parallel multiple mediator model of knowledge sharing in architectural design project teams. International Journal of Project Management, 32(1), 54-65.

Fawcett, S.E., Jones, S.L., \& Fawcett, A.M. (2012). Supply chain trust: The catalyst for collaborative innovation. Business Horizons, 55(2), 163-178.

Fornell, C., \& Larcker, D. F. (1981). Structural equation models with unobservable variables and measurement error: Algebra and statistics. Journal of Marketing Research, 18(3), 382-388.

Francis, G. (2001). Introduction to SPSS for Windows (3rd ed.). Sydney: Pearson Education Australia.

Gemino, A., Reich, B.H., \& Sauer, C. (2015). Plans versus people: Comparing knowledge management approaches in IT-enabled business projects. International Journal of Project Management, 33(2), 299-310.

Gilbert, J., \& Li-Ping Tang, T. (1998). An examination of organizational trust antecedents. Public Personnel Management, 27(3), 321-338.

Gray, B. (1989). Collaborating: Finding Common Ground for Multiparty Solutions. San Francisco, CA.: Jossey-Bass.

Greiner, M.E., Böhmann, T., \& Krcmar, H. (2007). A strategy for knowledge management. Journal of Knowledge Management, 11(6), 3-15.

Hair, J.F., Anderson, R.E., Babin, B.J., \& Black, W.C. (2010). Multivariate Data Analysis: A Global Perspective. Upper Saddle River, NJ: Pearson.

Harris, F., \& Lyon, F. (2013). Transdisciplinary environmental research: Building trust across professional cultures. Environmental Science \& Policy, 31, 109-119.

Hau, Y.S., Kim, B., Lee, H., \& Kim, Y. G. (2013). The effects of individual motivations and social capital on employees' tacit and explicit knowledge sharing intentions. International Journal of Information Management, 33(2), 356-366.

Hofstede, G.H. (2001). Culture's Consequences: Comparing Values, Behaviors, Institutions and Organizations Across Nations. Thousand Oaks CA.: Sage. 
Inaam, Z., Abderrahman, M., \& Yasmina, H. (2016). A framework of performance assessment of collaborative supply chain. IFACPapersOnLine, 49(12), 845-850.

Khalil, O.E., \& Seleim, A. (2010). Culture and knowledge transfer capacity: A crossnational study. International Journal of Knowledge Management, 6(4), 60-86.

Klijn, E.H., Edelenbos, J., \& Steijn, B. (2010). Trust in governance networks: Its impacts on outcomes. Administration \& Society, 42(2), 193-221.

Kottila, M.R., \& Rönni, P. (2008). Collaboration and trust in two organic food chains. British Food Journal, 110(4/5), 376-394.

Kucharska, W., \& Dąbrowski, J. (2016). Tacit knowledge sharing and personal branding: How to derive innovation from project teams? In A. Aaltio, \& M.T. Eskelinen (Eds.), Proceedings of the 11th European Conference on Innovation and Entrepreneurship (pp. 435-443). Finland, Jyväskylä: The JAMK University of Applied Science.

Kucharska, W., \& Kowalczyk, R. (2016). Trust, collaborative culture and tacit knowledge sharing in project management-A relationship model. In G.S. Erickson \& H.N. Rothberg (Eds.), Proceedings of the 13th International Conference on Intellectual Capital, Knowledge Management \& Organisational Learning (pp. 159-166). New York, USA: Ithaca College.

Kumar, A., \& Paddison, R. (2000). Trust and collaborative planning theory: The case of the Scottish planning system. International Planning Studies, 5(2), 205-223.

Lau, E., \& Rowlinson, S. (2009). Interpersonal trust and inter-firm trust in construction projects. Construction Management and Economics, 27(6), 539-554.

Lefebvre, J.M., \& Shiba, S. (2005). Collaboration and trust in the supply chain: The case of FAVI SA. Supply Chain Forum: An International Journal, 16(2), 90-95.

Lee, P., Gillespie, N., Mann, L., \& Wearing, A. (2010). Leadership and trust: Their effect on knowledge sharing and team performance. Management Learning, 41(4), 473-491.

Lewicki, R.J., \& Bunker, B.B. (1996). Developing and maintaining trust in work relationships. In R.M. Kramer \& T.M. Tyler (Eds.), Trust in Organizations: Frontiers of Theory and Research (pp. 114-139). Thousand Oaks, CA: Sage.

Mach, M., \& Baruch, Y. (2015). Team performance in cross cultural project teams: The moderated mediation role of consensus, heterogeneity, faultiness and trust. Cross Cultural Management, 22(3), 464-486.

Mueller, J. (2014). A specific knowledge culture: Cultural antecedents for knowledge sharing between project teams. European Management Journal, 32(2), 190-202.

Msanjila, S.S., \& Afsarmanesh, H. (2009). On hard and soft models to analyze trust life cycle for mediating collaboration. In Working Conference on Virtual Enterprises (pp. 381-392. Germany: Springer Berlin Heidelberg. 
Msanjila, S.S., \& Afsarmanesh, H. (2011). On modelling evolution of trust in organisations towards mediating collaboration. Production Planning and Control, 22(5-6), 518-537.

Orchard, C.A., Curran, V., \& Kabene, S. (2005). Creating a culture for interdisciplinary collaborative professional practice. Medical Education Online, 10(11), 1-13.

Oyewobi, L.O, Abiola-Falemu, O., \& Ibironke, O.T. (2016). The impact of rework and organisational culture on project delivery. Journal of Engineering, Design and Technology, 14(2), 214-237.

Paliszkiewicz, J.O. (2011). Trust management: Literature review. Management, 6(4), 315-331.

Park, J.G., \& Lee, J. (2014). Knowledge sharing in information systems development projects: Explicating the role of dependence and trust. International Journal of Project Management, 32(1), 153-165.

Pérez López, S., Manuel Montes Peón, J., \& José Vázquez Ordás, C. (2004). Managing knowledge: The link between culture and organisational learning. Journal of Knowledge Management, 8(6), 93-104.

Pishdad-Bozorgi, P., \& Beliveau, Y. J. (2016). Symbiotic relationships between integrated project delivery (IPD) and trust. International Journal of Construction Education and Research, 12(3), 179-192.

Portny, S.E. (2010). Project Management for Dummies. Indiana: John Wiley $\&$ Sons.

Rinehart, R.E., \& Kearl, K. (2016). Auto-, duo- and collaborative-ethnographies: "caring" in an audit culture climate. Qualitative Research Journal, 16(3), $1-16$.

Robinson, J.P., Shaver, P.R., \& Wrightsman, L.S. (1991), Criteria for scale selection and evaluation. In J.P. Robinson, P.R. Shaver \& L.S. Wrightsman (Eds.), Measures of Personality and Social Psychological Attitudes (pp. 1-15). San Diego, CA: Academic Press.

Rutten, W., Blaas-Franken, J., \& Martin, H. (2016). The impact of (low) trust on knowledge sharing. Journal of Knowledge Management, 20(2), 199214.

Smith, R.O. (2008). The paradox of trust in online collaborative groups. Distance Education, 29(3), 325-340.

Steiger, J.H., \& Lind, J.C. (1980). Statistically based tests for the number of common factors. Paper presented at the Annual meeting of the Psychometric Society, lowa City, IA, 758.

Szulanski, G. (1996). Exploring internal stickiness: Impediments to the transfer of best practice within the firm. Strategic Management Journal, 17, 2743.

Taormina, R.J. (2009). Organizational socialization: The missing link between employee needs and organizational culture. Journal of Managerial Psychology, 24(7), 650-676. 
Thimm, H., \& Rasmussen, K. B. 2010. Information support services for intermediation tasks of collaborative networks. Journal of Universal Computer Science, 16(13), 1776-1800.

Thomas, G.F., Zolin, R., \& Hartman, J.L. (2009). The central role of communication in developing trust and its effects on employee involvement. Journal of Business Communication, 46(3), 287-310.

Wallace, N., \& Mello, J. (2015). Collaborative culture: The new workplace reality. Foresight: The International Journal of Applied Forecasting, (39), 31-35.

Wheaton, D.E. (1977). Assessing Reliability and Stability in Panel Models. Sociological Methodology. San Francisco: Jossey-Bass.

Van Oortmerssen, L.A., van Woerkum, C.M., \& Aarts, N. (2014). The visibility of trust: Exploring the connection between trust and interaction in a Dutch collaborative governance boardroom. Public Management Review, 16(5), 666-685.

Yang, L.R., Yen, H.F., \& Chiang, Y.F. (2012). A framework for assessing impacts of leadership competency on police project performance: Mediating role of job satisfaction and moderating role of project type. Policing: An International Journal of Police Strategies \& Management, 35(3), 528550.

Young, T., \& Milton, N. (2011). Knowledge Management for Sales and Marketing. Oxford: CP Chandos Publishing.

Zuo, J., Zillante, G., Zhao, Z.Y., \& Xia, B. (2014). Does project culture matter? A comparative study of two major hospital projects. Facilities, 32(13/14), 801-824.

\begin{abstract}
Polish)
Istnieje wiele teoretycznych i empirycznych dowodów na to, że zaufanie wpływa na kulturę współpracy. Odwrotna zależność również znajduje potwierdzenie w literaturze. Celem niniejszego artykułu jest zbadanie współzależności tych zmiennych w kontekście dzielenia się wiedza niejawnq $w$ organizacji projektowej. W tym celu przeprowadzono badanie na próbie 514 polskich specjalistów wykonujqcych różne funkcje i majqcych różne doświadczenie w zarzqdzaniu projektami w branży budowlanej. Metodq modelowania równań strukturalnych dokonano analizy wzajemnych relacji tych zmiennych. Uzyskane wyniki wskazujq, że istnieje nie tylko silna korelacja między zaufaniem a kulturq współpracy, lecz obie te zmienne charakteryzuje silny wpływ na dzielenie się wiedzq niejawnq. Kluczowq implikacjq praktycznq wynikajqca z badania jest potrzeba stymulowania zarówno kultury współpracy, jak i zaufania. Uzyskanie silnego efektu synergii płynqcej ze współoddziaływania umożliwi pełne wykorzystanie wiedzy niejawnej pracowników celem maksymalizacji wyników organizacji.
\end{abstract}

Słowa kluczowe: zaufanie, wiedza niejawna, kultura organizacyjna, kultura współpracy, zarzqdzanie projektami. 


\section{Biographical note}

Wioleta Kucharska, Ph.D. Eng., holds an Assistant Professor position at the Faculty of Management and Economics, Gdansk University of Technology, Poland. She has 12 years industrial experience in marketing management and was responsible for many market-related processes and projects that strongly required tacit knowledge sharing as a driver of success. She focuses on being effective as a manager and as a teacher, and being innovative and genuine as a scientist. 


\title{
The Impact of Trust on Entrepreneurship in Poland
}

\section{Marta Młokosiewicz ${ }^{1}$ and Sandra Misiak-Kwit ${ }^{2}$}

\begin{abstract}
In the global rankings of generalized trust, Poland occupies a lowly position. Only $1 / 3$ of Poles have a strong trust in strangers and roughly the same number believe that trust in business generally pays off. At the same time, only half of them believe that a market economy based on private enterprise is the best economic system for the country. According to the literature review a major factor in the development of entrepreneurship is trust in other economic actors. The aim of the article is to present the relation between trust and entrepreneurial activities in Poland. In this paper the hypothesis was adopted that the level of trust in the public sphere, especially in business relations in Poland, had an impact on the intensity of entrepreneurial activities. The analysed period comprises the years from 2002 to 2016. The article presents changes in the potential for social trust, including trust in business. Indicators of confidence include the percentage of people that have trust in different actors in Poland. A further part of the paper is devoted to the phenomenon of entrepreneurship in Poland. Among the indicators of entrepreneurship are the number of newly registered and deregistered entities, and entities that are new or deregistered from the REGON register per 10 thousand of population. Moreover, the innovation activity of enterprises in Poland has been described. At the end, relations between trust and entrepreneurial activities in Poland were examined. The data was analysed statistically with Pearson's correlation coefficients. The analysis of confidence and entrepreneurship is based mainly on the data published by the Polish Central Statistical Office and Public Opinion Research Centre.
\end{abstract}

Keywords: trust, confidence, social capital, entrepreneurship, innovativeness, Poland.

1 Marta Młokosiewicz, Ph.D., Assistant Professor, University of Szczecin, Faculty of Economics and Management, Department of Human Capital Management, ul. Mickiewicza 64, 71-101 Szczecin, Poland, e-mail: marta.mlokosiewicz@ usz.edu.pl.

2 Sandra Misiak-Kwit, Ph.D., Assistant Professor, University of Szczecin, Faculty of Economics and Management, Department of Human Capital Management, ul. Mickiewicza 64, 71-101 Szczecin, Poland, e-mail: s.misiak@wneiz.pl.

Received 12 May 2017; Revised 17 August 2017; Accepted 9 November 2017 


\section{INTRODUCTION}

In the global rankings of generalized trust Poland occupies a lowly position. Only $1 / 3$ of Poles place strong trust in strangers and roughly the same number believe that trust in business generally pays off. At the same time, only half of them believe that a market economy based on private enterprise is the best economic system for the country. According to the literature review, trust in other economic actors is a major factor in the development of entrepreneurship. Does the level of trust in Poland affect the number of entrepreneurial actions undertaken, and the number of businesses established and deregistered? Is there a relationship between the level of trust and innovative activity registered by enterprises? These questions contributed to the research on the relation between trust and entrepreneurial activities in Poland.

The objective of the article is to present the relation between trust and entrepreneurial activities in Poland. In this paper it was assumed that the level of trust existing in the public sphere, and particularly in business relations in Poland, had an impact on the intensity of undertaken entrepreneurial activities. The rest of this paper in organized into five sections. Section 2 deals with the literature review; section 3 discusses research methods; section 4 analyzes the results while section 5 discusses them. Section 6 concludes the paper. In the paper, changes in social trust potential were presented, including trust in the business sphere, for the period between 2002 and 2016. The percentage of individuals placing trust in various entities was adopted as trust indicators. A further part of the paper was dedicated to the phenomenon of entrepreneurship. This part features the data regarding the number of newly-registered and deregistered enterprises in a given year, as well as the number of entities newly-registered in and removed from the National Economy Register (the REGON register) per 10 thousand of population; innovative activity in the services and industry sectors was further described. Following that, the existence of a significant correlation between trust and manifestations of entrepreneurial activities was examined with the use of a Pearson correlation coefficient. The analysis of trust and entrepreneurship was chiefly based on figures obtained from the Chief Statistical Office (GUS) and the Centre for Public Opinion Research (CBOS).

\section{LITERATURE REVIEW}

Successful business activity and entrepreneurial activity are significantly influenced by the stable behavior of economic actors as well as by the transparency of the macro and micro business environment. These factors 
shape economic order and a sense of security, by building the institutional trust of the individuals starting their business activity and the entrepreneurs already operating in the market. Market participants are then convinced that the existing formal structures guarantee the responsible conduct of other entities, and due to possible sanctions imposed for breaking rules, they feel protected from the negative consequences of the actions of others (Pretty \& Ward, 2001). Institutional trust is grounded in legal forms; networks based on general social norms; and the rules applicable to a given sector. They may be equated with faith and an expectation that the other party will act in a predictable and universally acceptable fashion.

A high degree of social trust is beneficial to the economic sphere: it reduces transaction costs (frees up time and financial outlays) related to contract monitoring and enforcement, it facilitates co-operation and has a positive impact on enterprise innovativeness (de Clercq \& Dakhli, 2003; Kaasa, 2007; Keeley, 2007), it facilitates the co-ordination of group activities (also in the manufacturing environment), as well as the popularization and implementation of new technologies (Wallis, Killerby \& Dollery, 2004). According to the research results on the European Union countries, there is a strong positive correlation between an average level of social trust and a summary innovation index. High social trust in Denmark, Sweden, Finland, and Switzerland favors greater innovation in those countries as compared to other European states. An opposite situation, confirming the above-mentioned correlations, exists in Eastern Europe, and in particular in Bulgaria, Slovakia and Poland, as well as in Portugal, where a low degree of social trust accompanies a relatively low level of innovation (NBP, 2016).

The establishment and development of enterprises is strongly linked with the sphere of social principles. If social norms allow for dishonest conduct, which is further strengthened by informal networks of relations, and if justice cannot always be easily found within the existing legal forms, economic order is upset, and in place of institutional trust, distrust emerges. There is substantial consent to dishonesty in Poland (Młokosiewicz, 2015).

Trust in business relations - apart from the fact that it develops in an institutional context - also has its personal dimension. Personal trust is formed, on the one hand, through the prism of the history of previous interactions with business partners, and the resultant knowledge of the other party's professionalism, its honesty, reliability, and on the other hand - a person's inclination to trust arising from their personal traits, their openness to others and their ability to risk trusting an individual. Trust can be based on a calculation of profits and costs involved in starting cooperation - it is then a rational choice aimed at maximizing its usefulness based on a calculation of benefits arising from entering into a relationship. Along with a growing number 
of interactions, observation of mutual conduct and accumulated experiences, the risk of showing / not showing trust decreases, since the knowledge of the other party expands. Therefore, five dimensions play a material role in trust development: personal, calculation-based, institutional, perception-centered and knowledge-based dimensions (McKnight, Cummings \& Chervany, 1998). It must be emphasised that limitless trust has no place in business relations. Thus, trust in business rather needs to be viewed in terms of "confidence" and setting boundaries, rather than "trust" (Handy, 1995). The question of building one's own credibility becomes an issue of importance, which is not so much a task, but rather a process (Lewandowski, 2008, p. 178). As demonstrated by the results of the study titled Social capital and trust in Polish business 2015, only $38 \%$ of Polish entrepreneurs were aware of the connection between enterprise credibility and its economic condition - they admitted that undertaking actions aimed at raising enterprise credibility would increase its sales volume in the last 12 months. From the estimates presented in the aforementioned report, it arises that in 2014 the lack of enterprise credibility-boosting activities in Poland translated into losses resulting from lost contract opportunities to the tune of PLN 66.3 billion (approx. 3\% of GDP), whereas out of fear (demonstrated by as many as $52 \%$ entrepreneurs) of contractors' dishonesty, contracts worth between PLN 145 and 215 billion were not concluded (approx. 10\% of GDP). $35 \%$ of business people claimed that many transactions are not concluded, because potential business partners treat them as being anonymous and untested. On the other hand as many as $75 \%$ of the respondents admitted that "one still needs to be cautious in order to avoid being cheated" (Social Capital and Trust in Polish Business, 2015). Thus, a significant degree of distrust dominated in business relations.

The core of entrepreneurship is starting up business activity (Griffin, 1997, pp. 730-731; Targalski \& Francik, 2009, p. 21). Referring to the literature on the subject, the creation of new things and a time-consuming, work-intensive or risky process need to be recognized as fundamental entrepreneurial activity (Hisrich \& Peters, 1992, p. 6). According to the studies in the field of economics, innovativeness constitutes an inseparable part of the entrepreneurial activities undertaken. The result of an entrepreneurial process in such circumstances is the employment of possessed resources in a unique manner (Kraśnicka, 2002). In foreign literature the combination of the phenomenon of entrepreneurship with innovations has also been described for many years. According to Churchill and Lewis (1992, p. 27), an entrepreneurial process can be defined as formulating and discovering opportunities in order to create new values not only through innovation, but also through acquiring the requisite resources or managing the process of value development. In a document describing entrepreneurship in Europe (2003, pp. 5-6) the European Commission also 
indicates that entrepreneurship is not merely an attitude focused on the creation of a new value, but also on the application of innovation and creativity.

\section{RESEARCH METHODS}

While reviewing the literature an exploratory design was adopted. It was the initial stage of the research. It included data and information gathered from various books, articles, journals, and reports of both Polish and foreign publications that are relevant to the study. The secondary data was collected from the Chief Statistical Office (GUS) and the Centre for Public Opinion Research (CBOS) for the period extending from 2002-05 to 2015-16. Table 1 provides a summary of the data source and period involved. While analyzing the secondary data the descriptive design of quantitative nature has been used.

Table 1. Summary of data source and the period

\begin{tabular}{lll}
\hline Data description & Period & Sources \\
\hline Institutional trust & $2002-2016$ & GUS (2015); CBOS (2016) \\
$\begin{array}{l}\text { Trust in institutions in countries listed in } \\
\text { Edelman Trust Barometer }\end{array}$ & $2013-2016$ & Edelman Trust Barometer \\
Trust and distrust in Poland & $2002-2016$ & CBOS (2016) \\
Intensity of entrepreneurial activities & $2003-2015$ & GUS (2017) \\
Innovative activity in the industrial sector & $2005-2015$ & GUS (2017) \\
Innovative activity in the services sector & $2005-2015$ & GUS (2017) \\
\hline
\end{tabular}

In order to obtain the information on the correlation between variables (trust and entrepreneurial activities), Pearson's correlation coefficient was employed, using the data presented by CBOS and GUS. The percentage of individuals trusting various entities was assumed as trust indicators, whereas the number of enterprises per 10 thousand of population registered in the REGON register and deregistered from the REGON register was adopted as indicators of entrepreneurial conduct, furthermore, selected manifestations of innovative activity in the industry and services were taken into consideration.

\section{ANALYSIS}

\section{Trust in Poland}

A study conducted by GUS in the first half of 2015 demonstrates that $13.1 \%$ of Poles would be willing to take advantage of employment status for their own benefit in exceptional situations, and $5.1 \%$ would sometimes be willing 
to do so. Approximately $21 \%$ of the respondents believed that in exceptional situations or occasionally, unreliable or careless performance of work could be justified, while only $40 \%$ of those surveyed by GUS claimed that employing workers illicitly and handling private matters during work time at the expense of professional duties is never justified (GUS 2015). Furthermore, from the report it arises that over $28 \%$ of Poles were decidedly or rather dissatisfied with the conditions of operating a business. Only a half of those surveyed by GUS "decidedly" or "rather" trusted local authorities, a slightly lower percentage expressed trust in courts, whereas a far smaller proportion placed their trust in legislative and executive authorities - only every fourth Pole admitted to trusting the Sejm, the Senate and the Government (Table 2).

Table 2. Institutional trust in Poland between the years of 2002-2016*

\begin{tabular}{|c|c|c|c|c|c|c|c|c|}
\hline \multirow{2}{*}{ Item } & \multicolumn{8}{|l|}{ Year } \\
\hline & 2002 & 2004 & 2006 & 2008 & 2010 & 2012 & $2015 * *$ & 2016 \\
\hline $\begin{array}{l}\text { Local city / } \\
\text { municipal }\end{array}$ & 43 & 53 & 56 & 68 & 55 & 58 & 50 & 64 \\
\hline $\begin{array}{l}\text { authorities } \\
\text { Public } \\
\text { administration } \\
\text { officials }\end{array}$ & 31 & 33 & 38 & 53 & 42 & 45 & - & 50 \\
\hline Courts & 40 & 31 & 39 & 59 & 44 & 45 & 47 & 45 \\
\hline Government & 42 & 21 & 47 & 56 & 31 & 39 & 27 & 38 \\
\hline Sejm \& Senate & 28 & 21 & 30 & 39 & 21 & 29 & 25 & 30 \\
\hline Large enterprises & 27 & 35 & 32 & 42 & 35 & 35 & - & 37 \\
\hline
\end{tabular}

Notes: * percentage of responses: "I rather trust" and "I decidedly trust" given to the question: "Overall, do you trust or distrust the institutions listed?". The research was conducted in January of each year.

** for 2015, owing to the lack of CBOS's data for the period of 2003-2015, GUS's data was provided a percentage of responses "I rather trust" and "I decidedly trust".

Source: own work on the basis of: Social Trust, CBOS, Research report No 18/2016, Social values and trust in Poland in 2015, GUS 2015.

Institutional trust in Poland was also low in international rankings. According to the Edelman Trust Barometer in 2016, as many as 65\% of Poles were distrustful of institutions, while the average percentage of those trusting institutions out of all the individuals surveyed in the index of countries was $50 \%$. In recent years the percentage has remained at the same level, whereas the difference between trust in the public sphere in Poland and average trust placed in institutions in the countries included in the Edelman Trust Barometer has grown (Table 3). 
Table 3. Trust in institutions* in Poland in comparison to other countries listed in the Edelman Trust Barometer

\begin{tabular}{lllll}
\hline Years & $\mathbf{2 0 1 3}$ & $\mathbf{2 0 1 4}$ & $\mathbf{2 0 1 5}$ & $\mathbf{2 0 1 6}$ \\
Index value** & $34(48)$ & $32(47)$ & $36(46)$ & $35(50)$ \\
\hline
\end{tabular}

Notes: * percentage of individuals having trust in institutions (the government, business, media and NGO's).

** average value of the Trust Index for all the listed countries is shown in brackets.

Source: own work on the basis of: the Edelman Trust Barometer 2013-2016.

A fundamental increase in the percentage of Poles trusting others was recorded in 2008. From that year onwards, a still small proportion of approximately $1 / 4$ of CBOS's respondents were convinced that a majority of people were trustworthy, moreover, the percentage of those preferring to exercise caution in relations with others fell, though only slightly - in the years between 2012 and 2016 that figure was 3/4 of those surveyed (Table 4).

Table 4. Trust and distrust in Poland between the years of 2002-2016*

\begin{tabular}{|c|c|c|c|c|c|c|c|c|}
\hline \multirow{2}{*}{ Item } & \multicolumn{8}{|l|}{ Years } \\
\hline & 2002 & 2004 & 2006 & 2008 & 2010 & 2012 & 2014 & 2016 \\
\hline $\begin{array}{l}\text { Overall, a majority } \\
\text { of people can be } \\
\text { trusted } * *\end{array}$ & 19 & 17 & 19 & 26 & 26 & 23 & 22 & 23 \\
\hline $\begin{array}{l}\text { One needs to be } \\
\text { very cautious in } \\
\text { relations with } \\
\text { others** }\end{array}$ & 79 & 81 & 79 & 72 & 72 & 74 & 75 & 74 \\
\hline $\begin{array}{l}\text { Overall, do you } \\
\text { or don't you trust } \\
\text { strangers whom } \\
\text { you encounter } \\
\text { in various } \\
\text { situations*** }\end{array}$ & - & - & $30(3)$ & $33(4)$ & $30(4)$ & $32(2)$ & $33(2)$ & $31(1)$ \\
\hline $\begin{array}{l}\text { Overall, do you } \\
\text { trust the people } \\
\text { you work with on } \\
\text { a daily basis**** }\end{array}$ & $58(24)$ & $53(26)$ & $60(20)$ & $\begin{array}{l}64 \\
(21)\end{array}$ & $\begin{array}{l}66 \\
(18)\end{array}$ & $\begin{array}{l}67 \\
(17)\end{array}$ & $\begin{array}{l}62 \\
(20)\end{array}$ & $\begin{array}{l}63 \\
(18)\end{array}$ \\
\hline $\begin{array}{l}\text { Trusting business } \\
\text { partners usually } \\
\text { pays off** }\end{array}$ & 24 & 29 & 27 & 33 & 34 & 38 & 33 & 35 \\
\hline $\begin{array}{l}\text { Trusting business } \\
\text { partners usually } \\
\text { ends badly** }\end{array}$ & 45 & 46 & 44 & 40 & 42 & 37 & 40 & 40 \\
\hline
\end{tabular}


$* * * *$ opinions of the respondents working full- or part-time, as well as off and on; percentage of responses: "I rather trust"; responses "I decidedly trust" are given in brackets.

Source: own work on the basis of: Social trust, CBOS, Research report No 18/2016.

The first two statements in Table 4 verified the so-called generalised trust. While the next question referred to a rather more personal dimension of trust, probably that was why the greatest number of positive responses was recorded in this case - approximately $1 / 3$ of Poles claimed that they trust the strangers whom they encountered in various situations. About $60 \%$ of the individuals surveyed by CBOS, and since 2008 even more than $60 \%$ of them, "rather" trusted their colleagues, while $20 \%$ of Poles decidedly had trust in their colleagues. A far higher percentage of positive responses to that question than in the case of strangers, or "a majority of people", demonstrates the significance of the experience of mutual relations in developing trust between parties.

Trust in business relations was at a similar level as trust in strangers. In the period between the years of 2008-2016, slightly more than $1 / 3$ of people claimed that trust in business partners is generally beneficial, and when compared to the period of 2002-2006, the number of positive responses recorded grew. However, even more Poles $-40 \%$ to be exact, were of the opinion that trusting business partners typically ends badly.

\section{Entrepreneurial activities undertaken in Poland}

According to the literature review, a low level of trust, including trust in business relations, affects the conditions of enterprise operation. Analysis of data showing the willingness to undertake entrepreneurial activities, in confrontation with changes in the level of social trust can provide interesting results_regarding the relationship between these phenomena. While data on trust has been already presented, in this part of the paper the authors gathered the data indicating entrepreneurship and innovativeness in Poland. The total number of newly-registered enterprises in a given year and newlyregistered entities in the REGON register per 10 thousand of population is presented in Table 5. Examination of the data renders it evident that from 2005 the number of newly-registered enterprises was higher than during the base year (2003). Overall, the number of newly-registered enterprises in 2015 , in comparison to the base year, rose by over one hundred and six thousand. The greatest spike was observed in 2010, when the number of newly-registered entities in the REGON register per 10 thousand of population was also the greatest and it exceeded one hundred. Yet, one year later the greatest decline in new enterprise registration was recorded. 
Table 5. Intensity of entrepreneurial activities undertaken in the period between the years of 2003-2015 in Poland

\begin{tabular}{|c|c|c|c|c|}
\hline Years & $\begin{array}{l}\text { Total number of } \\
\text { newly-registered } \\
\text { enterprises }\end{array}$ & $\begin{array}{l}\text { Total number } \\
\text { of deregistered } \\
\text { enterprises }\end{array}$ & $\begin{array}{l}\text { Newly-registered } \\
\text { entities in the } \\
\text { REGON register } \\
\text { per } 10 \text { thou. } \\
\text { population }\end{array}$ & $\begin{array}{l}\text { Entities struck } \\
\text { off of the REGON } \\
\text { register per } 10 \\
\text { thou. population }\end{array}$ \\
\hline 2003 & 253519 & 144752 & 66 & 38 \\
\hline 2004 & 233520 & 194666 & 61 & 51 \\
\hline 2005 & 261507 & 214778 & 69 & 56 \\
\hline 2006 & 297302 & 271090 & 78 & 71 \\
\hline 2007 & 295033 & 242790 & 77 & 64 \\
\hline 2008 & 317954 & 244965 & 83 & 64 \\
\hline 2009 & 349656 & 357530 & 92 & 94 \\
\hline 2010 & 402005 & 237693 & 104 & 62 \\
\hline 2011 & 346087 & 383617 & 90 & 100 \\
\hline 2012 & 358367 & 252313 & 93 & 65 \\
\hline 2013 & 365487 & 269904 & 95 & 70 \\
\hline 2014 & 357351 & 304687 & 93 & 79 \\
\hline 2015 & 359973 & 292358 & 94 & 76 \\
\hline
\end{tabular}

Source: own work on the basis of GUS.

Providing that willingness to start one's own business is reflected in the number of registered entities, it can be assumed that the number of deregistered entities demonstrates a lack of willingness to own a business at a given place and time. It needs to be emphasised that the increment of deregistered businesses in 2015 in relation to the base year was greater than in the case of newly-registered companies and it amounted to over one hundred and forty seven thousand. The most intensive changes in the number of deregistered companies occurred between the years 2009-2012, while the highest indicator reflecting the number of entities struck off of the REGON register per 10 thousand of population, equaling 100, was observed in 2011. Comparing the number of newly-registered and deregistered enterprises in the examined period, it is worth noting that in the years 2009 and 2011 the number of deregistered businesses exceeded the number of those newlyregistered. Additionally, the difference between the number of new and deregistered enterprises was significantly smaller in 2015 (it amounted to over sixty seven thousand) than in 2003 (when it was over one hundred and eight thousand). These calculations lead to a conclusion that despite the increase in the number of new registrations, the spike of deregistered 
entities was greater and a disproportion between those figures narrowed down. The data can serve as confirmation of the difficult conditions for running a business in Poland.

The paper examines not only the data concerning the numbers of new and closed enterprises, but also the statistics demonstrating innovative operations of enterprises in the industrial sector (Table 6) and in the services sector (Table 7). Because the data for some previous years was unavailable, a slightly shorter research period was assumed.

Table 6. Innovative activity in Poland in the industrial sector in the period between the years of $2005-2015$ (\% enterprises)

\begin{tabular}{lllll}
\hline Years & Industry in total & $\begin{array}{l}\text { New, improved } \\
\text { products (for an } \\
\text { enterprise) }\end{array}$ & $\begin{array}{l}\text { New products } \\
\text { for the market }\end{array}$ & $\begin{array}{l}\text { New, improved } \\
\text { processes }\end{array}$ \\
\hline 2005 & 42.04 & - & - & 32.86 \\
2006 & 23.68 & 16.14 & 7.82 & 19.70 \\
2007 & 37.40 & 28.50 & 14.75 & 25.64 \\
2008 & 21.39 & 15.57 & 9.39 & 17.18 \\
2009 & 18.06 & 12.66 & 6.96 & 13.76 \\
2010 & 17.10 & 12.10 & 6.75 & 12.86 \\
2011 & 16.10 & 11.23 & 6.12 & 12.36 \\
2012 & 16.51 & 11.19 & 5.63 & 12.44 \\
2013 & 17.13 & 11.01 & 5.71 & 12.82 \\
2014 & 17.52 & 11.72 & 6.20 & 12.95 \\
2015 & 17.58 & 11.77 & 6.49 & 13.03 \\
\hline
\end{tabular}

Source: own work on the basis of GUS. Retrieved from https://bdl.stat.gov.pl/BDL/dane/podgrup/temat -08.02 .2017 .

Irrespective of the fact as to whether the analysis focuses on a percentage of businesses introducing overall innovations in the industrial sector, or separate innovations in the form of new processes or new products for the entire market, or only for a given enterprise, a distinct decline becomes evident when compared to the base year. Enterprises operating in the industrial sector in Poland were becoming less and less innovative in the examined period: in 2005 it was recorded that about $42 \%$ of enterprises implemented innovations, while in 2015 that figure was down to only $17 \%$. The most frequently implemented innovations concerned new or improved processes, while new products were far less frequently introduced to the market by companies. However, it needs to be stressed that the dynamics of change in recent years was low and, although since 2012 the percentage 
of innovation implementing enterprises has been on the rise, that rise was insignificant.

Table 7. Innovative activity in Poland in the services sector in the period between the years of $2005-2015$ (\% enterprises)

\begin{tabular}{lllll}
\hline Years & Services in total & $\begin{array}{l}\text { New, improved } \\
\text { products }\end{array}$ & $\begin{array}{l}\text { New products } \\
\text { for the market }\end{array}$ & $\begin{array}{l}\text { New, improved } \\
\text { processes }\end{array}$ \\
\hline 2005 & - & - & - & - \\
2006 & 21.22 & 13.15 & 7.22 & 17.15 \\
2007 & - & - & - & - \\
2008 & 16.12 & 10.66 & 6.51 & 12.76 \\
2009 & 13.95 & 7.99 & 4.41 & 10.70 \\
2010 & 12.79 & 7.87 & 4.27 & 9.99 \\
2011 & 11.57 & 6.35 & 3.35 & 8.97 \\
2012 & 12.38 & 7.05 & 3.43 & 9.11 \\
2013 & 11.41 & 5.81 & 2.81 & 8.50 \\
2014 & 11.41 & 6.78 & 3.95 & 8.39 \\
2015 & 9.79 & 4.82 & 2.28 & 7.39 \\
\hline
\end{tabular}

Source: own work on the basis of GUS. Retrieved from https://bdl.stat.gov.pl/BDL/dane/podgrup/temat.

In the services sector similar relations may be observed (Table 6) as in the industrial sector. The percentage of enterprises implementing innovations in services was increasingly smaller in the analysed period. It is also worth emphasising that it was lower than in the industrial sector. In 2006, 21.22\% of companies in the services sector implemented innovations, whereas in the industrial sector that figure stood at $23.68 \%$. In turn, in 2005 only $9.79 \%$ of enterprises in the services sector and $17.58 \%$ of enterprises in the industrial sector could be considered as innovative.

\section{DISCUSSION}

The objective of the article was to present the correlation between trust and entrepreneurial activities in Poland. Table 8 presents the obtained results. From Table 8 it arises that four of the analyzed relations proved to be significant. A strong negative correlation was observed between caution in relations with others, as well as the conviction that trust in business partners usually ends badly, and the number of deregistered enterprises from the REGON register. This could mean that increased caution in business relations contributed to the decreased number of deregistered entities. 
Table 8. Trust and entrepreneurship in Poland - correlations ${ }^{12}$

\begin{tabular}{lll}
\hline No. Item & $\begin{array}{l}\text { Entities newly- } \\
\text { registered in the } \\
\text { REGON register per } 10 \\
\text { thou. population }\end{array}$ & $\begin{array}{l}\text { Entities deregistered } \\
\text { from the REGON } \\
\text { register per 10 thou. } \\
\text { population }\end{array}$ \\
\hline 1. $\quad$ Overall, a majority of people & $\begin{array}{l}0.630 \\
(1.812)\end{array}$ & 0.713 \\
can be trusted & -0.726 & $-2.278)$ \\
2. In relations with others one & $-0.767^{*}$ \\
needs to be very cautious & $(-2.359)$ & $(-2.670)$ \\
3. Trust in business partners & $0.801^{*}$ & $0.845^{*}$ \\
usually pays off & $(2.987)$ & $(3.526)$ \\
4. Trust in business partners & -0.740 & $-0.782^{*}$ \\
usually ends badly & $(-2.457)$ & $(-2.807)$ \\
5. Overall, do you trust the & 0.486 & 0.709 \\
people you work with on & $(1.244)$ & $(2.248)$ \\
a daily basis & & 0.228 \\
6. Average trust in institutions3 & 0.246 & $(0,523)$ \\
\hline
\end{tabular}

Notes: $1 r$ correlation coefficient in the table is given in bold

$2 t$ coefficient in the table is given in brackets; significance at the level of $\alpha=0.05$; $t \boldsymbol{\alpha}=2.571$

3 on the basis of Table 1

* statistically significant correlation

Source: own calculations on the basis of Tables 2, 4 and 5 .

Furthermore, a strong positive correlation was observed between the number of registrations as well as the number of businesses deregistered from the REGON register and the conviction that trust in business partners usually pays off. The results might suggest that in Polish circumstances trust in business might not actually pay off, despite previous optimism in the attitude to relations with others (reflected in the correlation between trust and newlyregistered entities). The conclusions drawn from the conducted analysis further demonstrate that trust in institutions might not have a significant impact on decisions of registering and deregistering a company.

On the basis of the accumulated data, the relation between enterprise innovative activity (both industrial and service-providing enterprises - Tables 6 and 7) and institutional trust (Table 2), generalized and personal trust (Table 4) was analyzed. Only three out of the calculated correlation coefficients proved to be significant. There was a strong positive correlation between trust in the government and innovations (overall) in the industry (Pearson's $r$ correlation coefficient assumed the value of $0.819, t=3.193$ for $t \alpha=3.182$, $\alpha=0.05)$. Moreover, a strong negative correlation was found between the conviction that trust in business partners pays off and innovations (overall) in the industry (Pearson's $r$ correlation coefficient assumed the value of $0.792, t=-2.903$ for $t \alpha=2.776, \alpha=0.05$ ), as well as between the conviction 
that trust in business partners pays off and innovations concerning new and improved processes in industry (Pearson's $r$ correlation coefficient assumed the value of $-0.841, t=-3.470$ for $t \alpha=2.776, \alpha=0.05$ ).

\section{CONCLUSION}

In the paper, changes in the potential of social trust were presented, including trust in the business sphere, in the period between the years of 2002-2016, adopting the percentage of individuals placing trust in various entities as trust indicators. Subsequently, the manifestations of entrepreneurial activities in Poland were analysed, presenting the data regarding the number of newlyregistered and deregistered companies in a given year, as well as newlyregistered entities and the ones struck off of the REGON register per 10 thousand of population. Furthermore, innovative activity in the services and the industrial sector was described.

In the paper a hypothesis was adopted that trust development in the public sphere, and in particular in business relations in Poland, affected the intensity of entrepreneurial activities. The deliberations show that both institutional and personal trust, as well as positive norms and values that contribute to high levels of trust, are important to the development of entrepreneurial initiatives. The conducted analysis proved that trust in institutions was fairly low in Poland, also with reference to the European average. What is more, a low level of generalised trust was noted. On average, the trust indicator in business partners was approximately 10 percentage points higher. A significant percentage of Poles were dissatisfied with the conditions of operating a business. They demonstrated a significant degree of distrust regarding contractors' credibility and reliability, which in the context of substantial social acceptance of unethical behavior, does not surprise. Thus, it seems that the distrust persistent in the society and business relations supressed entrepreneurial activities.

From the data presented in the paper it arises that the number of newlyregistered companies has grown and Poles' willingness to set up a business is increasing. However, it needs to be stressed that simultaneously the number of companies deregistered from the REGON register rose, and that rise was greater than in the case of new registrations. On those grounds one could venture a claim that the conditions for conducting business activity in Poland were hard. The implementation of innovations in the industrial and services sectors was adopted as another indicator of entrepreneurial activities. The data showed a decline of entrepreneurial activity among Polish companies since, over the analysed years, the share of enterprises implementing innovations has been falling. On the grounds of the figures presented it can 
be concluded that enterprises in the industrial sector were more innovative than the ones in the services sector.

Pearson's correlation coefficient was applied in order to confirm or reject the hypothesis regarding the correlation between trust and intensity of entrepreneurial activities. The obtained results did not allow us to confirm unequivocally the adopted research hypothesis. Not all analysed correlations proved to be statistically significant. Such confirmation was only possible with regard to the relation between trust placed in the government and innovation in the industry. In the remaining cases, the observed significant correlations confirmed a universal conviction in Poland that in business relations "one can never be too cautious". It seems that in order to reverse that tendency, a change of norms and values presently persisting in the social mind would be crucial, including drawing the attention of the market agents to the need for procedural, and not task-based, development of one's own credibility. Lack of trust in business to some extent results from the negative experiences of interactions with other entities. However, due to the fact that coexistence of the discussed phenomena (trust - entrepreneurship, trust - innovativeness), might have its source in a number of other factors such as legal, market, demographic, economic, cultural, and so forth, the examined relations require further in-depth analyses, taking into consideration larger data sets. The results obtained in the paper should not be treated as strong conclusions, but rather as a contribution to further research on the verification of a hypothesis which assumes that the level of trust existing in the public sphere had an impact on innovativeness and the intensity of undertaken entrepreneurial activities. Such research would allow us to get more detailed responses to the questions posed in the paper's introduction. It would also be interesting to get answers to the following questions:

- Is a high level of trust in Poland necessary for the intensification of entrepreneurial or innovative activities?

- What is the role of social trust against the background of the other factors determining innovativeness and entrepreneurship?

- Can trust be regarded as an indirect indicator (mediator) that shapes itself against the background of the other determinants of entrepreneurship and innovativeness? Does trust strengthen their impact?

\section{References}

Audretsch, D.B. (2003). Entrepreneurship: A Survey of the Literature. Prepared for the European Commission, Enterprise Directorate General, Institute for Development Studies. London: Indiana and Centre for Economic Policy Research. 
CBOS. (2016). Zaufanie Społeczne. Komunikat z Badań nr 18. Warszawa: CBOS.

Churchill, N.C., \& Lewis, V.L. (1992). The five stages of small business growth. In W.A. Sahlman, \& H.H. Stevenson (Eds.), The Entrepreneurial Venture. Boston: Harvard Business School Publications.

Commission of the European Communities. (2003). Green Paper, Entrepreneurship in Europe. Brussels.

de Clercq, D. \& M. Dakhli (2003), Human capital, social capital, and innovation: A multi-country study. Vlerick Leuven Gent Working Paper Series 2003/18. Gent: Vlerick Leuven Gent Management School.

Edelman Trust Barometer. (GUS).

Główny Urząd Statystyczny, Bank Danych Lokalnych. Retrieved from https:// bdl.stat.gov.pl/BDL

Griffin, R.W. (1997). Podstawy Zarzq̨dzania Organizacjami. Warszawa: PWN.

Handy, Ch. (1995). Trust and the virtual organization. Harvard Business Review, May-June, 40-50.

McKnight, D., Cummings, L.L., \& Chervany, N.L. (1998). Trust formation in new organizational relationship. Academy of Management Review, 23(3), 473-490.

Hisrich, R.D., \& Peters, M.P. (1992). Entrepreneurship. Boston: Irvin.

GUS, (2015). Wartości i zaufanie społeczne w Polsce w 2015 r. Warszawa: GUS.

Kaasa, A. (2007). Effects of different dimensions of social capital on innovation: Evidence from Europe at the regional level. Faculty of Economics and Business Administration Working Paper 69. Tartu: University of Tartu.

Kapitał społeczny i zaufanie w polskim biznesie. Skrót raportu. (2015). Krajowy Rejestr Długów i Rzetelna Firma.

Keeley, B. (2007). Human capital: How what you know shapes your life, OECD Insights. Paris: OECD Publishing.

Kraśnicka, T. (2002). Przedsiębiorczość jako podmiot badań ekonomistów. Ekonomia, 4, 187-200.

Lewandowski, E. (2008). Charakter Narodowy Polaków i Innych. Warszawa: Muza.

Misiak, S. (2014). Innowacje wprowadzane przez samozatrudnione kobiety w Polsce - studium przypadków. Zeszyty Naukowe Małopolskiej Wyższej Szkoły Ekonomicznej w Tarnowie, 1(24), 149-158.

Misiak-Kwit, S. (Ed.) (2015). Entrepreneurship and human capital in theory and practice. Chosen aspects. Gospodarowanie Kapitałem Ludzkim. Zeszyt 7. Szczecin: volumina.pl.

Młokosiewicz, M. (2015). Społeczna percepcja przedsiębiorczości w Polsce w kontekście etycznym. In K. Włodarczyk (Ed.), Kapitał ludzki w gospodarce i organizacji. Wybrane problemy. Seria Gospodarowanie kapitałem ludzkim, 25-43. Zeszyt 8. Szczecin: volumina.pl.

Młokosiewicz, M. (2016). Zaufanie jako kompetencja osobista w miejscu pracy. Marketing i Rynek, 3, 640-649. 
NBP. (2016). Potencjał Innowacyjny Gospodarki: uwarunkowania, determinanty, perspektywy. Warszawa: NBP.

Pech, R., \& Cameron, A. (2006). An entrepreneurial decision process model describing opportunity recognition. European Journal of Innovation Management, 9(1), 61-78.

Pretty, J., \& Ward H. (2001). Social Capital and the Environment. World Development, 29(2), 209-227.

Targalski, J., \& Francik, A. (2009). Przedsiębiorczość i Zarzq̨dzanie Firmq. Teoria i Praktyka. Warszawa: Wydawnictwo C. H. Beck.

Wallis, J., Killerby, P., \& Dollery, B. (2004). Social Economics and Social Capital. International Journal of Social Economics, 31(3), 239-258.

\begin{abstract}
Polish)
W światowych rankingach uogólnionego zaufania Polska sytuuje się na dalszych pozycjach. Jedynie 1/3 Polaków ma zdecydowane zaufanie do nieznajomych i mniej więcej tyle samo sqqdzi, że zaufanie w interesach na ogół się opłaca. Jednocześnie tylko połowa z nich uważa, że gospodarka rynkowa oparta na prywatnej przedsiębiorczości jest najlepszym dla kraju systemem gospodarczym. W literaturze dotyczq̨cej przedsiębiorczości wskazuje się zaś, że istotnym czynnikiem jej rozwoju jest zaufanie do innych uczestników życia gospodarczego. Celem artykułu jest ukazanie relacji między zaufaniem a działaniami przedsiębiorczymi w Polsce. $W$ niniejszym opracowaniu założono, że kształtowanie się zaufania $w$ sferze publicznej, a zwłaszcza $w$ relacjach biznesowych w Polsce miało wpływ na intensywność działań przedsiębiorczych. Za okres badawczy przyjęto lata 2002-2016. W artykule ukazano zmiany $w$ potencjale zaufania społecznego, $w$ tym zaufania $w$ biznesie. Za wskaźniki zaufania przyjęto odsetek osób ufajq̨cych różnym podmiotom w Polsce. Dalszq część artykułu poświęcono zjawisku przedsiębiorczości. W tej części ukazano dane dotyczqce liczby przedsiębiorstw nowozarejestrowanych oraz wyrejestrowanych w danym roku, a także jednostek nowozarejestrowanych oraz wykreślonych z REGON na 10 tysięcy ludności; opisano również działalność innowacyjnq w sektorze usług oraz przemysłowym. Następnie zbadano, czy istniał istotny zwiq̨zek między zaufaniem a przejawami działań przedsiębiorczych posługujqc się współczynnikiem korelacji liniowej Pearsona. W analizie zaufania i przedsiębiorczości oparto się głównie na danych GUS oraz CBOS.
\end{abstract}

Keywords: zaufanie, kapitał społeczny, przedsiębiorczość, innowacyjność, Polska.

\title{
Biographical notes
}

Marta Młokosiewicz, Ph.D., is an Assistant Professor at the Department of Human Capital Management of the Faculty of Economics and Management of the University of Szczecin. She holds a PhD in Economics from the University of Szczecin. The domain of her scientific research activity comprises social capital (particularly enterprise social capital, organizational trust, trust management) and also ethics in management and corporate social responsibility. She is an 
author of several dozen publications in scientific journals and monographs. She has actively participated (also as a member of organizing committees) in numerous national and international conferences and scientific workshops.

Sandra Misiak-Kwit, Ph.D., is an Assistant Professor at the University of Szczecin - Department of Human Capital Management. Her main research areas include entrepreneurship, self-employment of women, human resources management, business ethics, communication, and business relations. She holds a PhD in Management from the University of Szczecin. She is an author of several dozen publications. She has conducted classes at such universities as: Ningbo University and Guangdong University of Foreign Studies in China, Kelaniya University in Sri Lanka, Caucasus University in Georgia, Pamukkale University in Turkey, National Academy of Science of Ukraine and University of Food Technologies in Ukraine. 



\title{
Developing Entrepreneurial Skills. An Educational and Intercultural Perspective
}

\section{Ramona - Diana Leon ${ }^{1}$}

\begin{abstract}
The research aims to determine how the economic and business administration faculties within the European Union member states are contributing to the development of students' entrepreneurial skills. Therefore, a case study strategy is employed which concentrates on the most important business schools from the European Union member states; thus, 267 syllabuses from 21 higher education institutions are identified and analyzed. The results prove that European business schools manage to develop most of the required entrepreneurial skills among their students. Their graduates are both task and people oriented. On the one hand, they value performance, are capable of solving problems and taking calculated risks. On the other hand, they know how to communicate and collaborate within a team. Besides, it may be stated that the analyzed educational programs are combining the "about entrepreneurship" approach with "for entrepreneurship" perspective; they focus on developing cognitive, functional, and behavioral competences by combining lectures with active learning techniques. These actions are influenced by cultural specificity and have an impact on a country's capacity to be a top performer, in terms of entrepreneurship development. These findings have both theoretical and practical implications. On a theoretical level, they extend the literature regarding the development of entrepreneurial skills by providing concrete information about the skills on which the academic curricula focus. On a practical level, they provide valuable insights regarding the skills that the future entrepreneurs will have; these will influence their behavior in a business environment no matter whether they will choose to be the owner of a business or an enterprising employee.
\end{abstract}

Keywords: entrepreneurship, risk-taking, communication, university, European Union.

1 Ramona - Diana Leon, Senior Lecturer, National University of Political Studies and Administration, 30A Expozitiei Blvd., Sector 1, 012104, Bucharest, Romania, e-mail: ramona.leon@facultateademanagement.ro. 


\section{INTRODUCTION}

Within the framework of a dynamic and unpredictable environment, entrepreneurship appears as a possible incentive for sustainable development. According to GEM (2014), this is a complex activity that fosters economic growth through innovation, job creation and wealth. Entrepreneurs are those responsible for challenging the status-quo, discovering new profitable opportunities, and exploiting new ways of doing things. But what skills do they have and where did they acquire them?

\section{LITERATURE REVIEW}

The European Council (2006) labelled entrepreneurship as one of the eight key competences that all individuals should have in order to facilitate business creation and innovation (Landström, Harirchi \& Åström, 2012) and to have a successful professional life (Daniel, Costa, Pita \& Costa, 2017); the entrepreneur is seen not only as a person who is capable of taking risks and starting a business but also as an individual who uses his/her skills and characteristics in order to create value in a company (Gundry, Ofstein \& Kickul, 2014). Thus, the programs developed in higher education institutions start to focus on teaching and improving individual's entrepreneurial skills (Daniel et al., 2017; Hannon, 2006; Katz, 2008; Schelfhout, Bruggeman \& de Maeyer, 2016), and take into account the fact that their graduates may become either self-employed or innovative employees.

However, their task gets harder when it comes to defining which skills they should develop. As can be noticed from Table 1, plenty of research has been made regarding entrepreneurial skills and various elements are included under this label. The diversification process occurs somehow naturally if Chell's (2013) approach is taken into account. According to this, the entrepreneurial skills are multi-dimensional and combine know-how, emotions and behavior. In other words, they are a complex set of rational, emotional and spiritual knowledge. Any combination of this kind that fosters innovation and value creation can be labeled as "entrepreneurial skills".

On the other hand, Chell's (2013) definition suits the mission of any higher education institution that aims to develop students' knowledge and to teach them how to act and react under certain circumstances. Thus, the higher education institution acts as a knowledge incubator; it provides a controlled and safe environment in which students can discover and develop their characteristics, acquire new knowledge, feel the "taste" of a challenge/success/failure, understand themselves and others, and improve their creativity, autonomy, and responsibility. 
Table 1. Entrepreneurial skills, a theoretical perspective

\begin{tabular}{|c|c|}
\hline $\begin{array}{l}\text { Entrepreneurial } \\
\text { skills }\end{array}$ & Author/-s (year) \\
\hline Performance & Athayde (2009); Chiru, Tachiciu, and Ciuchete (2012); \\
\hline & $\begin{array}{l}\text { Cunningham (1991); Draycott and Rae (2011); Gibb (2002); Lans, } \\
\text { Verstegen, and Mulder (2011); Mitchelmore and Rowley (2010); } \\
\text { Moberg et al. (2014); Morris, Webb. Fu, and Singhal (2013). }\end{array}$ \\
\hline Creativity & Athayde (2009); Chang and Rieple (2013); Cunningham (1991); \\
\hline & $\begin{array}{l}\text { Draycott and Rae (2011); Draycott, Rae and Vause (2011); Gibb } \\
\text { (2002); Hodzic (2016); Lans et al. (2011); Mitchelmore and } \\
\text { Rowley (2010); Moberg et al. (2014); Morris et al. (2013); Tiwari } \\
\text { (2011). }\end{array}$ \\
\hline Taking initiative & $\begin{array}{l}\text { Cui, Sun, Xiao, and Zhao (2016); Draycott and Rae (2011); Gibb } \\
\text { (2002); Hodzic (2016); Mitchelmore and Rowley (2010); Moberg } \\
\text { et al. (2014); Morris et al. (2013). }\end{array}$ \\
\hline Risk-taking & Covin and Wales (2012); Cui et al. (2016); Cunningham (1991); \\
\hline & $\begin{array}{l}\text { Draycott et al. (2011); Gibb (2002); Moberg et al. (2014); Morris } \\
\text { et al. (2013); Taatila and Down (2012). }\end{array}$ \\
\hline Perseverance & Gibb (2002); Hodzic (2016); Lans et al. (2011); Mitchelmore and \\
\hline & \\
\hline Leadership & $\begin{array}{l}\text { Athayde (2009); Chang and Rieple (2013); Cunningham (1991); } \\
\text { Draycott and Rae (2011); Draycott et al. (2011); Gibb (2002); } \\
\text { Lans et al. (2011); Man (2012); Mitchelmore and Rowley (2010); } \\
\text { Moberg et al. (2014); Morris et al. (2013); Schelfhout, Dochy, and } \\
\text { Janssens (2004). }\end{array}$ \\
\hline Communication & $\begin{array}{l}\text { Chang and Rieple (2013); Draycott and Rae (2011); Gibb (2002); } \\
\text { Hodzic (2016); Mitchelmore and Rowley (2010); Moberg et al. } \\
\text { (2014); Morris et al. (2013); Schelfhout et al. (2004); Taatila and } \\
\text { Down (2012). }\end{array}$ \\
\hline Problem solving & $\begin{array}{l}\text { Chang and Rieple (2013); Chiru et al. (2012); Cunningham (1991); } \\
\text { Draycott and Rae (2011); Gibb (2002); Hodzic (2016); Lans et al. } \\
\text { (2011); Mitchelmore and Rowley (2010); Moberg et al. (2014); } \\
\text { Morris et al. (2013); Schelfhout et al. (2004). }\end{array}$ \\
\hline Collaboratic & Chiru et al. (2012); Draycott and Rae (2011); Draycott et al. \\
\hline & $\begin{array}{l}\text { D11); Hodzic (2016); Mitchelmore and Rowley (2010); Moberg } \\
\text { al. (2014); Morris et al. (2013); Schelfhout et al. (2004). }\end{array}$ \\
\hline Learning & $\begin{array}{l}\text { Chang and Rieple (2013); Cunningham (1991); Draycott et al. } \\
\text { (2011); Gibb (2002); Hodzic (2016); Lans et al. (2011); Man } \\
\text { (2012); Mitchelmore and Rowley (2010); Moberg et al. (2014); } \\
\text { Morris et al. (2013); Schelfhout et al. (2004). }\end{array}$ \\
\hline Time & $\begin{array}{l}\text { Chell (2008); Frese (2007); Schenkel et al. (2009); Zahra et al. } \\
\text { (2006). }\end{array}$ \\
\hline
\end{tabular}

Each of these characterizes an entrepreneur - the owner of a company or the person who displays enterprising behavior (Gibb, 2002). 
Since a university's mission is somehow linked to entrepreneurship, the academic programs have three different ways of approaching the issue, namely: "about", "for" and "through" entrepreneurship (Gibb, 2002; Pittaway \& Edwards, 2012). The first ones are more traditional and adopt a theoretical perspective; they focus on delivering knowledge about what entrepreneurship is and how an entrepreneur should behave (Pittaway \& Edwards, 2012). Thus, they foster students' cognitive competences. The second ones are learner-centered and process-based, and try to combine theoretical and practical approaches; they concentrate on content and entrepreneurial skills, and support the development of both cognitive and functional competences. The last ones have a more pedagogical orientation and exploit the value of experiential learning; they aim to foster students' non-cognitive entrepreneurial skills (Moberg, 2014).

Still, Ahmad (2015) states that the current education programs are too mechanistic to encourage entrepreneurial behavior despite the fact that most researchers (Fayolle, 2013; Gibb, 2002) sustain that the last two perspectives from which entrepreneurial education is approached are the most effective ones. The former takes mainly into account the educational programs "about entrepreneurship" while the latter focuses on the programs which are based on active learning. According to Bonwell and Eison (1991), these involve using teaching methods such as teamwork, problem solving, case studies, simulations, role playing, and field work.

However, Leon (2015) proves that cultural specificity influences educators' choices for a specific teaching activity. Starting from Hofstede's traditional dimensions, it is demonstrated that there is a strong relationship between the cultural dimensions and the use of theoretical activities. According to Leon (2015, p. 687), "the log-odds of using theoretical activities within the courses will increase by 3.280 times (if masculinity increases with one unit), by 3.232 times (if uncertainty avoidance is augmented with one unit), and by 0.584 times (if the level of power distance is increased with one unit)". Synthesizing, the activities that are used during the courses define students' future skills and depend on cultural specificity.

Given the fact that cultural specificity represents "a pattern characterized by shared beliefs, attitudes, norms, roles and values that are organized around a theme and that can be found in certain geographic regions during a particular historic period" (Triandis, 1995, p. 43), and defines how people think, act, and react under certain circumstances, its influence upon the entrepreneurial skills development should be taken into consideration. Although various models are developed in order to measure and understand cultural specificity (Hall, 1981; House, Hanges, Javidan, Dorfman \& Gupta, 2004; Kluckhohn \& Strodbeck, 1961; Trompenaars, 1993), Hofstede's (2001) dimensions 
remain the cornerstone of intercultural management; these include: power distance (PD), individualism/collectivism, masculinity/femininity, uncertainty avoidance (UA), long term orientation (LTO), and indulgence.

Power distance (PD) concentrates on people's ability to accept how authority and control are distributed among the members of a society (Hofstede, 2001). It emphasizes individuals' preoccupation for formal or informal authority, status-seeking, privileges, and obedience. Therefore, in a high power distance society, there is a clear demarcation between those who are in charge and subordinates, the focus is on formal authority and privileges, and orders are executed, not discussed. On the other hand, in a low power distance culture, the informal authority is the one that matters and is given by individual's competencies not social status. From an educational point of view, these elements have the power to inhibit the development of students' estimating capacity and ICT skills (Leon, 2015). Most of the people who come from a high power distance society think that they do not need to forecast future events since they are not the ones who call the shots; they are taught how to do things and not to think of what should be done.

Individualism/collectivism bring forward who matters the most: the individual or the group (Hofstede, 2001). In an individualistic society, one speaks for himself/herself and is responsible for his/her destiny. Therefore, individualism fosters the development of students' written and oral communication skills (Leon, 2015). On the other hand, in a collectivistic society, responsibility is divided among the members and individuals are always looking for moral support and loyalty.

Masculinity / Femininity highlights whether the members of a society value more personal achievement or quality of life (Hofstede, 2001). In the first case, people are oriented towards success, material possessions and proactivity while, in the second case, special attention is given to personal relationships, spiritual possessions and the balance between work and family time. So far, it has been proven that masculinity inhibits the development of students' oral communication skills (Leon, 2015).

Uncertainty avoidance (UA) reflects people's tolerance to mistakes and unexpected situations (Hofstede, 2001). The cultures that have a high level of uncertainty avoidance encourage perfection and reject everything that does not follow the general standards or challenges the status-quo. On the other hand, the cultures that have a low level of uncertainty avoidance understand that making mistakes is part of the learning process, and support innovation and experimentation. As a consequence, uncertainty avoidance tends to foster the development of students' ICT skills and estimating capacity (Leon, 2015).

Long/short term orientation measures individuals' perspectives on time and their connection with the past (Hofstede, 2001). The persons who come 
from a culture characterized by long term orientation favor hard work, value their roots, and are capable of sacrificing present for future benefits. On the other hand, those who belong to a culture characterized by short term orientation act based on the "here and now" principle. Within this framework, long term orientation inhibits students' written and oral communication skills and boosts the development of their learning and ICT skills (Leon, 2015).

Indulgence sheds light on individuals' attitudes towards the gratification of needs and life (Itim International, 2017). Those who come from an indulgent culture favor the gratification of needs, personal well-being, thinking outside of the box, enjoying life, having fun and going beyond the limits. Those who belong to a restraint society suppress the gratification of needs, value the strict social norms and support maintaining the status-quo.

Against this backdrop, several gaps are identified in the entrepreneurship literature. Firstly, there is nogeneral accepted framework on the entrepreneurial skills that a university should develop among its graduates. The studies written so far present an ideal image and avoid pointing out the concrete characteristics of a higher education graduate, from an entrepreneurship perspective. Secondly, when it comes to teaching methods, an extensive list of techniques which support active learning is promoted. However, there is no prior research regarding their use in higher education institutions and their contribution to the development of students' entrepreneurial skills. Last but not least, none of the previously developed researches analyzes the influence that cultural specificity has on the development of entrepreneurial skills, in the higher education institutions. These gaps are filled by the current research.

\section{RESEARCH METHODS}

This research aims to determine how the economic and business administration faculties from within the European Union member states are contributing to the development of their students' entrepreneurial skills. Therefore, the following research objectives are pursued: (i) to identify the most important business schools from the European Union member states; (ii) to analyze their syllabuses; (iii) to determine the entrepreneurial skills that the graduates are assumed to possess, according to the academic curricula; (iv) to analyze the compatibility between the skills developed during the bachelor studies and the "classical" entrepreneurial skills; (v) to analyze how the entrepreneurial skills that the business schools aim to develop among the future human resources affect a country's capacity to be a best performer, based on the Entrepreneurship Development Index; and (vi) to determine the influence that cultural specificity has on developing students' entrepreneurial skills. 
Table 2. Selection criteria

\begin{tabular}{lll}
\hline Criterion & Reference level & Units of analysis \\
\hline Presence in the QS Worlds University & Present & 293 \\
Rankings & $>12.000$ students & 226 \\
Number of students & High & 185 \\
Research level & $>25$ years & 182 \\
Experience on the educational services & & \\
market & First & 24 \\
Position occupied in national ranking & Syllabus in English & 21 \\
Access to information & &
\end{tabular}

Source: Leon (2014).

Further, a case study strategy is employed which concentrates on the most important business schools from within the European Union member states. This domain is chosen due to the fact that their graduates are going to work in the most dynamic economic sectors, namely: banking, commerce, business administration, tourism etc. (Leon, 2016). Following the same methodology as Leon (2014), the best business school from each European Union member state is selected. The selection criteria are: (i) presence in the QS Worlds University Rankings; (ii) number of students; (iii) research level; (iv) experience in the educational services market; (v) position occupied in national ranking; and (vi) access to information (Table 2). In the end, 21 business schools are selected and analyzed (Table 3).

Table 3. Case study units

\begin{tabular}{llll}
\hline No. & University & No. & University \\
\hline 1 & University of Vienna & 12 & Trinity College Dublin \\
2 & Katholieke Universiteit Leuven & 13 & University of Bologna \\
\hline 3 & University of St. Kliment Ohridski & 14 & University of Latvia \\
4 & University of Zagreb & 15 & Vilnius University \\
5 & Charles University & 16 & University of Amsterdam \\
6 & Aarhus University & 17 & University of Coimbra \\
7 & University of Tartu & 18 & University of Ljubljana \\
8 & Ecole normale supérieure, Paris & 19 & Universitat Autónoma de Barcelona \\
9 & Technische Universität München & 20 & University of Cambridge \\
10 & University of Crete & 21 & Alexandru loan Cuza University \\
11 & University of Szeged & & \\
\hline
\end{tabular}

In the second stage, for each of the selected higher education institutions, the courses taught at undergraduate level are identified. Then, 267 
syllabuses are identified and analyzed. To each of them a content analysis is applied; the units of analysis are represented by educational goals, practical assignments, and teaching methods (Leon, 2016). The analysis focuses on the main sections of the syllabuses and does not take into account the hours dedicated to each subject.

Based on the literature review, it is assumed that the main entrepreneurial skills that students should achieve by the end of the undergraduate studies are: (i) performance orientation (Athayde, 2009; Chiru et al., 2012; Cunningham, 1991; Draycott \& Rae, 2011; Gibb, 2002; Lans et al., 2011; Mitchelmore \& Rowley, 2010; Moberg et al., 2014; Morris et al., 2013); (ii) creativity (Athayde, 2009; Chang \& Rieple, 2013; Cunningham, 1991; Draycott \& Rae, 2011; Draycott et al., 2011; Gibb, 2002; Hodzic, 2016; Lans et al., 2011; Mitchelmore \& Rowley, 2010; Moberg et al., 2014; Morris et al., 2013; Tiwari, 2011); (iii) taking the initiative (Cui et al., 2016; Draycott \& Rae, 2011; Gibb, 2002; Hodzic, 2016; Mitchelmore \& Rowley, 2010; Moberg et al., 2014; Morris et al., 2013); (iv) risk-taking (Covin \& Wales, 2012; Cui et al., 2016; Cunningham, 1991; Draycott et al., 2011; Gibb, 2002; Moberg et al., 2014; Morris et al., 2013; Taatila \& Down, 2012); (v) perseverance (Gibb, 2002; Hodzic, 2016; Lans et al., 2011; Mitchelmore \& Rowley, 2010; Moberg et al., 2014); (vi) leadership (Athayde, 2009; Chang \& Rieple, 2013; Cunningham, 1991; Draycott \& Rae, 2011; Draycott et al., 2011; Gibb, 2002; Lans et al., 2011; Man, 2012; Mitchelmore \& Rowley, 2010; Moberg et al., 2014; Morris et al., 2013; Schelfhout et al., 2004); (vii) communication (Chang \& Rieple, 2013; Draycott \& Rae, 2011; Gibb, 2002; Hodzic, 2016; Mitchelmore \& Rowley, 2010; Moberg et al., 2014; Morris et al., 2013; Schelfhout et al., 2004; Taatila \& Down, 2012); (viii) problem solving (Chang \& Rieple, 2013; Chiru et al., 2012; Cunningham, 1991; Draycott \& Rae, 2011; Gibb, 2002; Hodzic, 2016; Lans et al., 2011; Mitchelmore \& Rowley, 2010; Moberg et al., 2014; Morris et al., 2013; Schelfhout et al., 2004); (ix) collaboration / teamwork (Chiru et al., 2012; Draycott \& Rae, 2011; Draycott et al., 2011; Hodzic, 2016; Mitchelmore \& Rowley, 2010; Moberg et al., 2014; Morris et al., 2013; Schelfhout et al., 2004); (x) learning skills (Chang \& Rieple, 2013; Cunningham, 1991; Draycott et al., 2011; Gibb, 2002; Hodzic, 2016; Lans et al., 2011; Man, 2012; Mitchelmore \& Rowley, 2010; Moberg et al., 2014; Morris et al., 2013; Schelfhout et al., 2004); and (xi) time management skills (Chell, 2008; Frese, 2007; Schenkel et al., 2009; Zahra et al., 2006).

In the third phase, a multinomial logistic regression is employed in order to establish how the entrepreneurial skills that the business schools aim to develop among the future human resources affect a country's capacity to be among the best performers. This technique is chosen due to the fact that: (i) it is more robust to violations of assumptions of multivariate normality; 
(ii) it does not assume a linear relationship between the dependent and independent variables; (iii) independent variables are not necessarily unbounded; and (iv) normally distributed errors terms are not assumed (Bayaga, 2010; Tabachnick, Fidell \& Osterlind, 2001). Therefore, at this level, the focus is on predicting a nominal dependent variable (country's capacity to be among the best performers) based on more continuous independent variables (entrepreneurial skills). Practically, the nominal dependent variable is determined based on the Global Entrepreneurship Index (Acs, Szerb \& Autio, 2017) while the continuous independent variables are represented by the entrepreneurial skills, identified in the previous stage.

Last but not least, theattention switchesfrom the effects of entrepreneurial skills development to the factors that may influence it. Therefore, Poisson regression is applied; this is a generalized linear model which: (i) describes the transformations of the conditional mean of the dependent variable; (ii) allows the dependent variable to have conditional distributions other than the normal; and (iii) uses numerical and categorical explanatory variables (Hoffman, 2004; Moksony \& Hegedus, 2014). Thus, the dependent variable is represented by each of the previously identified entrepreneurial skills while the independent variable is represented by Hofstede's cultural dimensions, namely: power distance (PD), individualism / collectivism, masculinity / femininity, uncertainty avoidance (UA), long / short term orientation (LTO), and indulgence (Itim International, 2017).

\section{ANALYSIS/STUDY}

As it can be noticed from Figure 1, most of the educational programs aim to develop students' functional competences by making sure they acquire specialized knowledge. Although the analyzed business schools remain faithful to the traditional mission of a university - providing the needed knowledge for individuals' and society's development -, they are also trying to adapt their curricula to labor market demands and to foster skills development. Therefore, they boost the improvement of several entrepreneurial skills, namely: learning, problem solving, risk-taking, time management, oral and written communication, and teamwork skills. These are supposed to facilitate the identification and exploitation of various opportunities. Thus, in light of these, the graduates will be able to recognize various sources of opportunities, to solve complex problems, to expose themselves to an uncertain environment, to meet deadlines, to communicate and collaborate with others, and to learn from experience and from others. 


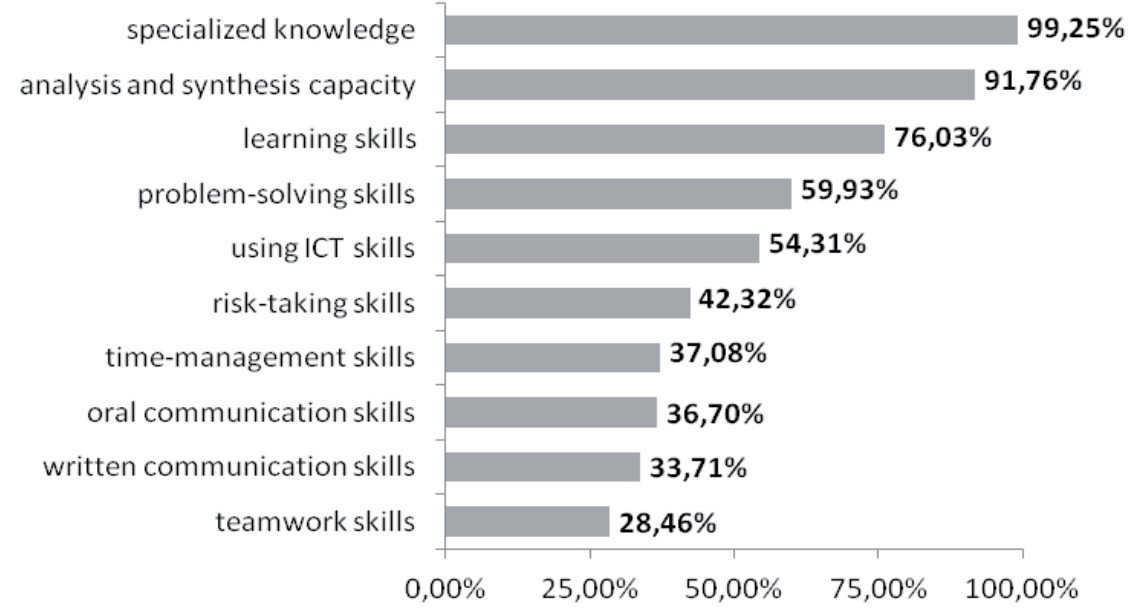

Figure 1. The skills which the courses taught at undergraduate level focus on

Source: Leon (2016).

Nevertheless, the European business schools take into account the challenges that occur in the business environment and on the labor market. Therefore, almost $54.31 \%$ of the analyzed syllabuses shed light on the importance of knowing how to use ICTs. On the one hand, this comes in line with a company's dependence on technology, and on the other hand, it exploits Millennials predisposition of being connected through ICTs. If the elements presented in the previous section are taken into consideration, it can be argued that these skills were neglected by the entrepreneurial studies which have been developed so far; however, they were not neglected by the European educational programs.

The development of these skills is ensured by combining passive and active learning (Figure 2). Although most courses (98.88\%) still have their roots in a traditional and theoretical perspective, much progress has been made as more than $50 \%$ of the courses use active learning methods. Case studies, problem solving activities and discussions are frequently used within the programs. This emphasizes a slow transition from "about entrepreneurship" to "for entrepreneurship" educational programs. In other words, the European economic and business administration faculties have started to switch from a theoretical approach to a more complex one that combines theory with practice. As a consequence, they will continue to provide wellqualified human resources to the labor market. However, there is still a lot to do since they are far from using experiential learning and simulations. 


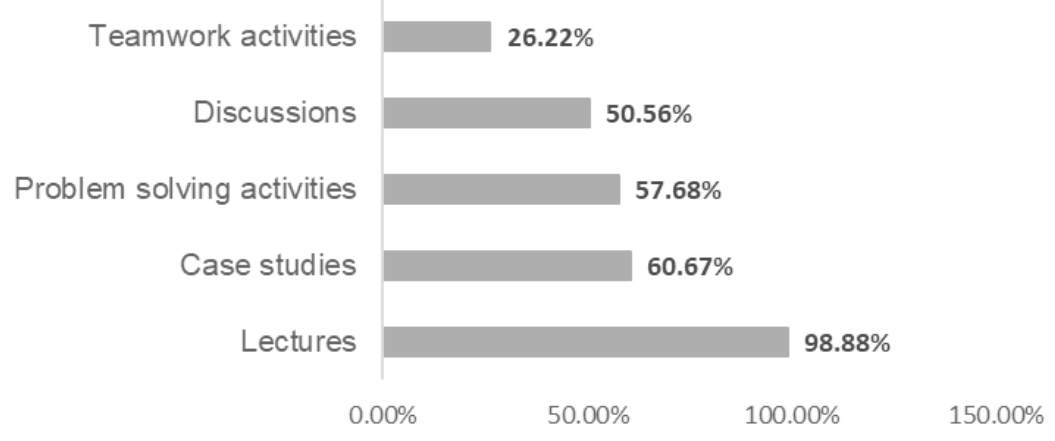

Figure 2. The teaching methods that are frequently used in the European higher education institutions

Source: Leon (2016).

According to the data presented in Table 4, the European business schools manage to develop most of the required entrepreneurial skills. Their graduates are both task and people oriented. On the one hand, they value performance, are capable of solving problems and taking calculated risks. On the other hand, they know how to communicate and collaborate within a team. However, their entrepreneurial skills are more appropriate for an enterprising employee than for a business owner. In order to complete the demands for the second approach, the higher education programs should encourage their students to be creative, perseverant, and to take the initiative. In other words, they have to challenge their mental models, and to teach them how to think outside of the box and to stand up for their beliefs.

As aforementioned, the European business schools use active learning for developing students' entrepreneurial skills. Within the bachelor programs, they focus on improving cognitive, functional, and behavioral competences by combining lectures with active learning techniques (problem solving, teamwork, discussions, and case studies). Nevertheless, it may be stated that their programs are combining an "about entrepreneurship" with a "for entrepreneurship" perspective. However, further attention should be offered to a "through entrepreneurship" approach which involves using experiential learning and simulations; so far, none of the analyzed educational programs take these teaching methods into account. Therefore, their graduates lack creativity, initiative and perseverance. 
Table 4. Comparative analysis between the required entrepreneurial skills and those developed among the business schools' graduates

\begin{tabular}{lll}
\hline Entrepreneurial skills & Required & Developed \\
\hline Performance orientation & + & + \\
Creativity & + & - \\
Taking the initiative & + & - \\
Risk-taking & + & + \\
Perseverance & + & - \\
Leadership & + & - \\
Communication & + & + \\
Problem solving & + & + \\
Collaboration / Teamwork & + & + \\
Learning & + & + \\
Time management & + & + \\
\hline
\end{tabular}

This situation has effects not only at the individual and organizational level but also at the national level. In order to determine the impact that the development of the current entrepreneurial skills have on the national entrepreneurship phenomena, multinomial logistic regression is employed. Thus, a country's capacity to be among the top performers is the dependent variable, while the independent variables are considered to be risk-taking, communication, problem solving, teamwork, performance orientation, and time management skills. Since the Pearson Chi-Square value is small (Table 5) and the $p$-value is not statistically significant $(p=0.091>0.05)$ then it can be argued that the model fits the data well.

Table 5. Multinomial logistic regression between the skills developed within the European business schools and entrepreneurship development. Goodness of fit

\begin{tabular}{llll}
\hline & Chi-Square & df & Sig. \\
\hline Pearson & 21.436 & 14 & .091 \\
Deviance & 13.635 & 14 & .477 \\
\hline
\end{tabular}

The assumption is confirmed also by data presented in Table 6 which analyzes whether the variables included in the model are statistically improving the prediction of the dependent variable or not. Given the fact that $p=0.017<0.05$, it can be stated that the skills developed within the European business schools are influencing countries' capacity to be among the top performers when it comes to entrepreneurship development. 
Table 6. Multinomial logistic regression between the skills developed within the European business schools and entrepreneurship development. Model fitting

\begin{tabular}{lllll}
\hline \multirow{2}{*}{ Model } & \multicolumn{2}{l}{$\begin{array}{l}\text { Model fitting criteria } \\
\text {-2 Log likelihood }\end{array}$} & \multicolumn{2}{l}{ Likelihood ratio tests } \\
Chi-square & df & Sig. \\
\hline Intercept & 29.065 & & & \\
$\begin{array}{l}\text { Only } \\
\text { Final }\end{array}$ & 13.635 & 15.430 & 6 & .017 \\
\hline
\end{tabular}

The influence that each variable has on a country's capacity to be among the best performers is presented in Table 7. This shows that all six independent variables are statistically significant $(p<0.05)$.

Table 7. Multinomial logistic regression between the skills developed within the European business schools and entrepreneurship development. Likelihood ratio tests

\begin{tabular}{lllll}
\hline \multirow{2}{*}{ Effect } & \multicolumn{3}{l}{ Model fitting criteria } & \multicolumn{3}{l}{ Likelihood ratio tests } \\
\cline { 2 - 5 } & $\begin{array}{l}\mathbf{- 2} \text { Log likelihood of reduced } \\
\text { model }\end{array}$ & Chi-square & df & Sig. \\
\hline Intercept & 19.026 & 5.392 & 1 & .020 \\
Risk-taking & 13.703 & .068 & 1 & .047 \\
Communication & 13.636 & .001 & 1 & .007 \\
Problem-solving & 27.786 & 14.152 & 1 & .000 \\
Teamwork & 16.644 & 3.009 & 1 & .038 \\
Performance & 16.487 & 2.852 & 1 & .019 \\
orientation & & & & \\
\hline Time management & 13.683 & .049 & 1 & .026 \\
\hline
\end{tabular}

Note: The chi-square statistic is the difference in -2 log-likelihoods between the final model and a reduced model. The reduced model is formed by omitting an effect from the final model. The null hypothesis is that all parameters of that effect are 0 .

The previous analysis brings forward the effects that entrepreneurial education has on the development of the national economy. However, it is restricted by various economic, social, demographic and cultural factors. Within this framework, special attention is given to cultural specificity which has the power to shape what people think, feel and do.

Table 8. Poisson regression between entrepreneurial skills development and Hofstede's cultural dimensions. Omnibus test

\begin{tabular}{llcl}
\hline Dependent variable & Likelihood ratio Chi-square & df & Sig. \\
\hline Risk-taking skills & 13.012 & 6 & .043 \\
Communication skills & 11.218 & 6 & .028 \\
\hline
\end{tabular}




\begin{tabular}{llll}
\hline Dependent variable & Likelihood ratio Chi-square & df & Sig. \\
\hline Problem-solving skills & 3.600 & 6 & .031 \\
Teamwork & 11.490 & 6 & .047 \\
Performance orientation & 2.533 & 6 & .065 \\
Time management skills & 9.022 & 6 & .017 \\
\hline
\end{tabular}

Notes: Dependent variable: risk-taking.

Model: (Intercept), PD, Individualism, Masculinity, UA, LTO, Indulgence.

a. Compares the fitted model against the intercept-only model.

In order to test the influence of cultural specificity on entrepreneurial skills development, Poisson regression is employed. Firstly, the analysis aims to determine whether entrepreneurial skills development is subject to Hofstede's (2001) cultural dimensions or not. Based on the data presented in Table 8, it can be stated that, in most of the cases, the independent variables (Hofstede's cultural dimensions) collectively improve the model over the intercept-only model. In other words, since the $p$-value is smaller than 0.05 , the overall model is statistically significant for entrepreneurial skills development. The only exception is represented by the development of performance orientation skills where $p=0.065$. When it comes to developing the risk-taking skills, not all the independent variables are statistically significant. According to the $p$-value presented in Table 9, three cultural dimensions should be taken into consideration, namely: uncertainty avoidance $(p=0.045)$, long term orientation $(p=0.035)$, and indulgence $(p=0.008)$.

Table 9. Poisson regression between the development of the risk-taking skills and Hofstede's cultural dimensions. Test of model effects

\begin{tabular}{|c|c|c|c|c|}
\hline \multirow[t]{2}{*}{ Source } & \multirow[b]{2}{*}{ Wald Chi-square } & \multicolumn{2}{|l|}{ Type III } & \\
\hline & & df & Sig. & \\
\hline (Intercept) & & 20.027 & 1 & .000 \\
\hline PD & & .984 & 1 & .321 \\
\hline Individualism & & .375 & 1 & .540 \\
\hline Masculinity & & .161 & 1 & .689 \\
\hline UA & & .038 & 1 & .045 \\
\hline LTO & & & & .035 \\
\hline 3.736 & & & & \\
\hline 1 & & & & \\
\hline Indulgence & & 6.957 & 1 & .008 \\
\hline
\end{tabular}

Notes: Dependent variable: risk-taking.

Model: (Intercept), PD, Individualism, Masculinity, UA, LTO, Indulgence. 
The effect that each of them has on the development of the risk-taking skills is presented in Table 10.

Table 10. Poisson regression between the development of the risk-taking skills and Hofstede's cultural dimensions. Parameter estimates

\begin{tabular}{|c|c|c|c|c|c|c|c|c|c|c|}
\hline \multirow[t]{2}{*}{ Parameter } & \multirow[t]{2}{*}{ B } & \multirow[t]{2}{*}{$\begin{array}{l}\text { Std. } \\
\text { error }\end{array}$} & \multicolumn{2}{|c|}{$\begin{array}{l}95 \% \text { Wald } \\
\text { confidence } \\
\text { interval }\end{array}$} & \multicolumn{3}{|c|}{ Hypothesis test } & \multirow[t]{2}{*}{$\operatorname{Exp}(B)$} & \multicolumn{2}{|c|}{$\begin{array}{l}\text { 95\% Wald } \\
\text { confidence } \\
\text { interval for } \\
\text { Exp(B) }\end{array}$} \\
\hline & & & Lower & Upper & $\begin{array}{l}\text { Wald Chi- } \\
\text { square }\end{array}$ & df & Sig. & & Lower & Upper \\
\hline (Intercept) & 2.270 & .5072 & 1.276 & 3.264 & 20.027 & 1 & .885 & 9.677 & 3.581 & 26.148 \\
\hline PD & -.286 & .2886 & -.852 & .279 & .984 & 1 & .321 & .751 & .427 & 1.322 \\
\hline Individualism & .227 & .3703 & -.499 & .953 & .375 & 1 & .540 & 1.255 & .607 & 2.592 \\
\hline Masculinity & -.084 & .2093 & -.494 & .326 & .161 & 1 & .689 & .920 & .610 & 1.386 \\
\hline UA & .091 & .4631 & -.817 & .998 & .038 & 1 & .045 & 1.095 & .442 & 2.713 \\
\hline LTO & -.587 & .3039 & -1.183 & .008 & 3.736 & 1 & .035 & .556 & .306 & 1.008 \\
\hline Indulgence & -.820 & .3108 & -1.429 & -.211 & 6.957 & 1 & .008 & .441 & .240 & .810 \\
\hline (Scale) & $1 a$ & & & & & & & & & \\
\hline
\end{tabular}

Notes: Dependent variable: risk-taking.

Model: (Intercept), PD, Individualism, Masculinity, UA, LTO, Indulgence.

So, within this framework, uncertainty avoidance (UA) has the most powerful influence on the development of risk-taking skills; its exponential value is 1.095. Long term orientation (LTO) is in second place with a 0.556 exponential value while indulgence is third (exponential value equals 0.441 ).

If communication skills are taken into consideration, it can be observed that they depend on masculinity and indulgence (Table 11). The former has an exponential value of 0.726 while the latter has an exponential value of 1.585. So, there is a $58.5 \%$ increase in the development of communication skills for each step that takes society closer to an indulgent one.

Table 11. Poisson regression between the development of the communication skills and Hofstede's cultural dimensions. Parameter estimates

\begin{tabular}{|c|c|c|c|c|c|c|c|}
\hline \multirow[t]{2}{*}{ Parameter } & \multirow[t]{2}{*}{ B } & \multirow{2}{*}{$\begin{array}{l}\text { Std. } \\
\text { error }\end{array}$} & $\begin{array}{l}\text { 95\% Wald } \\
\text { confidence } \\
\text { interval }\end{array}$ & Hypothesi & test & \multirow{2}{*}{$\operatorname{Exp}(B)$} & \multirow{2}{*}{$\begin{array}{l}\text { 95\% Wald } \\
\text { confidence } \\
\text { interval for } \\
\text { Exp(B) } \\
\text { Lower Upper }\end{array}$} \\
\hline & & & Lower Upper & $\begin{array}{l}\text { Wald } \\
\text { Chi- df } \\
\text { square }\end{array}$ & Sig. & & \\
\hline (Intercept) & 1.231 & .4647 & $.321 \quad 2.142$ & 7.0211 & .180 & 3.426 & $\begin{array}{ll}1.378 & 8.517\end{array}$ \\
\hline
\end{tabular}




\begin{tabular}{|c|c|c|c|c|c|c|c|c|c|c|}
\hline \multirow[t]{3}{*}{ Parameter } & \multirow[t]{3}{*}{ B } & \multirow{3}{*}{$\begin{array}{l}\text { Std. } \\
\text { error }\end{array}$} & \multicolumn{2}{|c|}{$\begin{array}{l}\text { 95\% Wald } \\
\text { confidence } \\
\text { interval }\end{array}$} & \multicolumn{3}{|c|}{ Hypothesis test } & \multirow[t]{3}{*}{$\operatorname{Exp}(B)$} & \multicolumn{2}{|c|}{$\begin{array}{l}\text { 95\% Wald } \\
\text { confidence } \\
\text { interval for } \\
\text { Exp(B) }\end{array}$} \\
\hline & & & & & Wald & & & & & \\
\hline & & & Lower & Upper & $\begin{array}{l}\text { Chi- } \\
\text { square }\end{array}$ & df & Sig. & & Lowe & Uppe \\
\hline PD & .192 & .3198 & -.435 & .818 & .359 & 1 & .549 & 1.211 & .647 & 2.267 \\
\hline Individualism & .250 & .3973 & -.529 & 1.028 & .395 & 1 & .530 & 1.283 & .589 & 2.796 \\
\hline Masculinity & -.320 & .2387 & -.788 & .148 & 1.796 & 1 & .008 & .726 & .455 & 1.159 \\
\hline UA & .411 & .4194 & -.411 & 1.233 & .959 & 1 & .327 & 1.508 & .663 & 3.431 \\
\hline LTO & -.532 & .3204 & -1.160 & .096 & 2.755 & 1 & .097 & .587 & .313 & 1.101 \\
\hline Indulgence & .460 & .2443 & -.018 & .939 & 3.552 & 1 & .025 & 1.585 & .982 & 2.558 \\
\hline (Scale) & $1 a$ & & & & & & & & & \\
\hline
\end{tabular}

Notes: Dependent variable: communication.

Model: (Intercept), PD, Individualism, Masculinity, UA, LTO, Indulgence.

a. Fixed at the displayed value.

Moreover, the development of problem solving skills is also a subject of cultural specificity (Table 12). At this level, only three cultural dimensions are statistically significant, namely: individualism $(p=0.034)$, masculinity ( $p$ $=0.008)$, and long term orientation $(p=0.031)$. Masculinity has the highest exponential value (1.028) while individualism has the lowest exponential value (0.831).

Table 12. Poisson regression between the development of the problem solving skills and Hofstede's cultural dimensions. Parameter estimates

\begin{tabular}{|c|c|c|c|c|c|c|c|c|c|c|}
\hline \multirow[t]{2}{*}{ Parameter } & \multirow[t]{2}{*}{ B } & \multirow[t]{2}{*}{$\begin{array}{l}\text { Std. } \\
\text { error }\end{array}$} & \multicolumn{2}{|c|}{$\begin{array}{l}\text { 95\% Wald } \\
\text { confidence } \\
\text { interval }\end{array}$} & \multicolumn{3}{|c|}{ Hypothesis Test } & \multirow[t]{2}{*}{$\operatorname{Exp}(B)$} & \multicolumn{2}{|c|}{$\begin{array}{l}\text { 95\% Wald } \\
\text { confidence } \\
\text { interval for } \\
\text { Exp(B) }\end{array}$} \\
\hline & & & Lower & Upper & $\begin{array}{l}\text { Wald Chi- } \\
\text { square }\end{array}$ & df & Sig. & & Lower & Upper \\
\hline (Intercept) & 1.970 & .3767 & 1.232 & 2.709 & 27.361 & 1 & .881 & 7.173 & 3.428 & 15.010 \\
\hline PD & -.048 & .2426 & -.523 & .428 & .038 & 1 & .844 & .954 & .593 & 1.534 \\
\hline Individualism & -.185 & .2968 & -.766 & .397 & .387 & 1 & .034 & .831 & .465 & 1.488 \\
\hline Masculinity & .027 & .1834 & -.332 & .387 & .022 & 1 & .008 & 1.028 & .718 & 1.472 \\
\hline UA & .325 & .3393 & -.340 & .990 & .920 & 1 & .338 & 1.385 & .712 & 2.692 \\
\hline LTO & -.147 & .2351 & -.608 & .314 & .392 & 1 & .031 & .863 & .544 & 1.368 \\
\hline Indulgence & .035 & .2067 & -.370 & .440 & .028 & 1 & .867 & 1.035 & .690 & 1.552 \\
\hline (Scale) & $1 a$ & & & & & & & & & \\
\hline
\end{tabular}

Notes: Dependent variable: problem solving. 
Model: (Intercept), PD, Individualism, Masculinity, UA, LTO, Indulgence.

a. Fixed at the displayed value.

In addition, the development of teamwork skills is supported by three cultural dimensions (Table 13), namely: individualism ( $p=0.036$ ), masculinity $(p=0.005)$, and indulgence $(p=0.027)$. As can be noticed, individualism has an exponential value of 0.615 . On the other hand, masculinity and indulgence may generate an increase in the advancement of teamwork skills by $11.30 \%$ and $85.00 \%$ respectively.

Table 13. Poisson regression between the development of the teamwork skills and Hofstede's cultural dimensions. Parameter estimates

\begin{tabular}{|c|c|c|c|c|c|c|c|c|c|c|}
\hline \multirow[t]{2}{*}{ Parameter } & \multirow[t]{2}{*}{ B } & \multirow{2}{*}{$\begin{array}{l}\text { Std. } \\
\text { error }\end{array}$} & \multicolumn{2}{|c|}{$\begin{array}{l}95 \% \text { Wald } \\
\text { confidence } \\
\text { interval }\end{array}$} & \multicolumn{3}{|c|}{ Hypothesis test } & \multirow[t]{2}{*}{$\operatorname{Exp}(B)$} & \multicolumn{2}{|c|}{$\begin{array}{l}\text { 95\% Wald } \\
\text { confidence } \\
\text { interval for } \\
\text { Exp(B) }\end{array}$} \\
\hline & & & & & $\begin{array}{l}\text { Wald } \\
\text { Chi- }\end{array}$ & df & Sig. & & & Upper \\
\hline (Intercept) & 1.447 & .5184 & .431 & 2.463 & $\begin{array}{l}\text { square } \\
7.793\end{array}$ & 1 & .689 & 4.251 & 1.539 & 11.741 \\
\hline PD & -.195 & .3950 & -.969 & .580 & .243 & 1 & .622 & .823 & .380 & 1.785 \\
\hline Individualism & -.486 & .4741 & -1.415 & .444 & 1.049 & 1 & .036 & .615 & .243 & 1.559 \\
\hline Masculinity & .107 & .2669 & -.416 & .630 & .160 & 1 & .005 & 1.113 & .660 & 1.877 \\
\hline UA & .226 & .4362 & -.629 & 1.081 & .269 & 1 & .604 & 1.254 & .533 & 2.948 \\
\hline LTO & -.355 & .3370 & -1.016 & .305 & 1.112 & 1 & .292 & .701 & .362 & 1.357 \\
\hline Indulgence & .615 & .2787 & .069 & 1.161 & 4.875 & 1 & .027 & 1.850 & 1.072 & 3.194 \\
\hline (Scale) & $1 a$ & & & & & & & & & \\
\hline
\end{tabular}

Notes; Dependent variable: teamwork.

Model: (Intercept), PD, Individualism, Masculinity, UA, LTO, Indulgence.

a. Fixed at the displayed value.

Last but not least, an intercultural influence can be identified when it comes to developing students' time management skills (Table 14). This is influenced by uncertainty avoidance $(p=0.003)$ which has an exponential value of 1.702 . In other words, a $70.20 \%$ increase in the development of time management skills can appear if the uncertainty avoidance (UA) increases by one unit. 
Table 14. Poisson regression between the development of the time management skills and Hofstede's cultural dimensions. Parameter estimates

\begin{tabular}{|c|c|c|c|c|c|c|c|c|c|c|}
\hline \multirow[t]{3}{*}{ Parameter } & \multirow[t]{3}{*}{ B } & \multirow{3}{*}{$\begin{array}{l}\text { Std. } \\
\text { Error }\end{array}$} & \multicolumn{2}{|c|}{$\begin{array}{l}\text { 95\% Wald } \\
\text { confidence } \\
\text { interval }\end{array}$} & \multicolumn{3}{|c|}{ Hypothesis test } & \multirow[t]{3}{*}{ Exp(B) } & \multicolumn{2}{|c|}{$\begin{array}{l}\text { 95\% Wald } \\
\text { confidence } \\
\text { interval for } \\
\text { Exp(B) }\end{array}$} \\
\hline & & & & & Wald & & & & & \\
\hline & & & Lower & Upper & $\begin{array}{l}\text { Chi- } \\
\text { Square }\end{array}$ & df & Sig. & & Lower & Upper \\
\hline (Intercept) & 1.435 & .4892 & .476 & 2.393 & 8.599 & 1 & .212 & 4.198 & 1.609 & 10.950 \\
\hline PD & -.180 & .3332 & -.833 & .473 & .291 & 1 & .589 & .835 & .435 & 1.605 \\
\hline Individualism & -.557 & .3923 & -1.326 & .212 & 2.014 & 1 & .156 & .573 & .266 & 1.236 \\
\hline Masculinity & -.116 & .2428 & -.592 & .360 & .227 & 1 & .634 & .891 & .553 & 1.434 \\
\hline UA & .532 & .4263 & -.304 & 1.367 & 1.557 & 1 & .003 & 1.702 & .738 & 3.925 \\
\hline LTO & -.005 & .2889 & -.572 & .561 & .000 & 1 & .985 & .995 & .565 & 1.752 \\
\hline Indulgence & .403 & .2470 & -.081 & .888 & 2.669 & 1 & .102 & 1.497 & .923 & 2.429 \\
\hline (Scale) & $1 a$ & & & & & & & & & \\
\hline
\end{tabular}

Notes; Dependent variable: time management

Model: (Intercept), PD, Individualism, Masculinity, UA, LTO, Indulgence

a. Fixed at the displayed value.

\section{CONCLUSION}

Synthesizing, the research objectives were achieved since: (i) the most important business schools from the European Union member states were identified; (ii) their syllabuses were analyzed; (iii) the entrepreneurial skills that the graduates are assumed to possess, according to the academic curricula, were brought forward; (iv) the compatibility between the skills developed during the bachelor studies and the "classical" entrepreneurial skills was emphasized; (v) the effects that the entrepreneurial education will have on country's capacity to be among the best performers, in terms of entrepreneurship development, was highlighted; and (vi) the influence that cultural specificity has on entrepreneurial skills development was emphasized.

As was previously demonstrated, the top ranking European business schools tend to concentrate on using active learning when it comes to developing students' entrepreneurial skills. However, their bachelor programs combine an "about entrepreneurship" with a "for entrepreneurship" perspective, and neglect the importance of a "through entrepreneurship" approach. As a consequence, their graduates acquire several entrepreneurial skills (like, risktaking, performance orientation, problem solving, communication, teamwork, and time management) but they lack creativity, initiative and perseverance; 
the three of them make a practical difference between a top performer and a "regular" entrepreneur that tries to do everything by the book.

What happens in the educational sector has implications at a business and national level. So, based on the multinomial logistic regression, it can be stated that several entrepreneurial skills can predict whether a country has the capacity to be among the top performers, in terms of entrepreneurship development, or not. Six skills have the ability to do this, namely: risk-taking, communication, problem solving, teamwork, performance orientation, and time management.

Nevertheless, the development of the entrepreneurial skills through the educational programs of European business schools is also conditioned by the national cultural profile (Table 14); the only exception is represented by performance orientation skills. So, a country's level of individualism tends to have an impact on the development of students' problem solving skills while its orientation towards masculinity is reflected in the development of problem solving, communication, and teamwork skills. Furthermore, the societies which have a high level of uncertainty avoidance (UA) focus on risk-taking and time management. Nevertheless, long term orientation (LTO) encourages risk-taking and problem solving while indulgence strengthens risk-taking, communication and teamwork.

Table 15. The connections between the entrepreneurial skills and Hofstede's cultural dimensions

\begin{tabular}{|c|c|c|c|c|c|}
\hline $\begin{array}{l}\text { Hofstede's cultural } \\
\text { dimensions }\end{array}$ & $\begin{array}{l}\text { Risk- } \\
\text { taking }\end{array}$ & $\begin{array}{l}\text { Problem- } \\
\text { solving }\end{array}$ & Communication & Teamwork & $\begin{array}{l}\text { Time } \\
\text { management }\end{array}$ \\
\hline \multicolumn{6}{|l|}{$P D$} \\
\hline Individualism & & $x$ & & & \\
\hline Masculinity & & $x$ & $x$ & $x$ & \\
\hline UA & $x$ & & & & $x$ \\
\hline LTO & $x$ & $x$ & & & \\
\hline Indulgence & $x$ & & $x$ & $x$ & \\
\hline
\end{tabular}

These findings have both theoretical and practical implications. On a theoretical level, they extend the literature regarding entrepreneurial skills by providing concrete information on the skills which the academic curricula focus on. On a practical level, they provide valuable insights regarding the skills of future entrepreneurs; these will influence their behavior in the business environment no matter whether they will choose to be self-employed or employees. Besides, it brings forward the link between cultural specificity and entrepreneurial skills development, and the effects that the latter 
has on a country's capacity to be among the best performers, in terms of entrepreneurship development.

Despite these valuable insights, this research is limited by the fact that it only considers a reduced number of higher education institutions and it is based on what is written in the syllabuses. In other words, it reflects what is happening in the best economic and business administration faculties and it neglects what is happening in other institutions. In addition, it uses the syllabuses as a reference point which means that it actually describes the goals of the academic curricula and not necessarily its results. Last but not least, the hours dedicated to each subject and the time lag between the period of studies and the real employment of the graduates are not taken in consideration.

Starting from these, at least three further research directions can be identified, namely: (i) extending the research on a significant sample of European higher education institutions; (ii) measuring the entrepreneurial skills of European business schools' graduates; and (iii) analyzing the real entrepreneurial skills developed among the graduates.

\section{Acknowledgments}

This paper is a revised and expanded version of a paper entitled 'University - A Knowledge Incubator for Developing Entrepreneurial Skills', presented at the 1st edition of the Entrepreneurs, Entrepreneurship conference, Faculty of Management, National University of Political Studies and Public Administration, Bucharest, Romania, 18-20 May 2017.

\section{References}

Acs, Z.J., Szerb, L., \& Autio, E. (2017). Global Entrepreneurship Index 2016. Washington, DC: The Global Entrepreneurship and Development Institute. Ahmad, S.Z. (2015). Entrepreneurship education in tourism and hospitality programs. Journal of Hospitality \& Tourism Education, 27(1), 20-29.

Athayde, R. (2009). Measuring enterprise potential in young people. Entrepreneurship Theory and Practice, 33(2), 481-500.

Bayaga, A. (2010). Multinomial logistic regression: Usage and application in risk analysis. Journal of Applied Quantitative Methods, 5(2), 288-297.

Bonwell, C., \& Eison, J. (1991). Active Learning: Creating Excitement in the Classroom. Washington, DC: The George Washington University.

Chang, J., \& Rieple, A. (2013). Assessing students' entrepreneurial skills development in live projects. Journal of Small Business and Enterprise Development, 20(1), 225-241.

Chell, E. (2008). The Entrepreneurial Personality: A Social Construction. London: Routledge.

Chell, E. (2013). Review of skill and the entrepreneurial process. International Journal of Entrepreneurship Behaviour and Research, 19(1), 6-31. 
Chiru, C., Tachiciu, L., \& Ciuchete, S.G. (2012). Psychological factors: Behavioural variables and acquired competencies in entrepreneurship education. Procedia-Social and Behavioural Sciences, 46, 4010-4015.

Cope, J. (2003). Entrepreneurial learning and critical reflection: Discontinuous events as triggers for 'higher-level' learning. Management Learning, 34, 429-450.

Corbett, A.C. (2005). Experimental learning within the process of opportunity identification and exploitation. Entrepreneurship Theory and Practice, 29, 473-491.

Covin, J.G., \& Wales, W.J. (2012). The measurement of entrepreneurial orientation. Entrepreneurship Theory and Practice, 36(4), 677-702.

Cui, Y., Sun, C., Xiao, H., \& Zhao, C. (2016). How to become an excellent entrepreneur: The moderating effect of risk propensity on alertness to business ideas and entrepreneurial capabilities. Technological Forecasting \& Social Change, 112, 171-177.

Cunningham, J. (1991). Defining entrepreneurship. Journal of Small Business Management, 29(1), 45-61.

Daniel, A.D., Costa, R.A., Pita, M., \& Costa, C. (2017). Tourism Education: What about entrepreneurial skills? Journal of Hospitality and Tourism Management, 30, 65-72.

Deakins, D., \& Freel, M. (1998). Entrepreneurial learning and the growth process in SMEs. The Learning Organization, 5, 144-155.

Draycott, M.C., \& Rae, D. (2011). Enterprise education in schools and the role of competency frameworks. International Journal of Entrepreneurial Behaviour \& Research, 17(2), 127-145.

Draycott, M.C., Rae, D., \& Vause, K. (2011). The assessment of enterprise education in the secondary education sector: A new approach? Education + Training, 53(8/9), 673-691.

European Commission (2008, March 30). Best Procedure Project: Entrepreneurship in Higher Education, Especially in Non-Business Studies. Final Report of the Expert Group. Retrieved from http://ec.europa.eu/ enterprise/entrepreneurship/supportmeasures/training education/index. $\mathrm{htm}$

European Commission (2012, September 20). Rethinking Education: Investing in skills for better socio-economic outcomes. Retrieved from http:// ec.europa.eu/education/policy/multilingualism/rethinking-education/en

European Commission (2013, January 9). Entrepreneurship 2020 action plan: Reigniting the entrepreneurial spirit in Europe. Retrieved from http://eurlex.europa.eu/LexUriServ/LexUriServ.do?uri=COM:2012:0795:FIN:en:PDF

European Council (2006, December 30). Recommendation of the European parliament and the council of 18 December 2006 on key competences for lifelong learning. Retrieved from http://eur-lex.europa.eu/legal-content/ EN/TXT/PDF/?uri=CELEX:32006H0962\& from=EN

Fayolle, A. (2013). Personal views on the future of entrepreneurship education. Entrepreneurship \& Regional Development, 25(7-8), 692-701. 
Frese, M. (2007). Performance - an action theory approach. In J.R. Baum, M. Frese \& R. Baron (Eds.), The Psychology of Entrepreneurship (pp. 151-188). London: Lawrence Erlbaum.

GEM (2014). Informe GEM España 2014. Santander: Universidad de Cantabria. Gibb, A.A. (2002). Creating conducive environments for learning and entrepreneurship: Living with, dealing with, creating and enjoying uncertainty and complexity. Industry \& Higher Education, 16(3), 135-148. Gundry, L.K., Ofstein, L.F., \& Kickul, J.R. (2014). Seeing around corners: How creativity skills in entrepreneurship education influence innovation in business. International Journal of Management Education, 12(3), 529-538. Hall, E.T. (1981). The Silent Language. New York: Doubleday.

Hamilton, E. (2011). Entrepreneurial learning in family business: a situated learning perspective. Journal of Small Business and Enterprise Development, 18(1), 8-26.

Hannon, P. D. (2006). Teaching pigeons to dance: Sens and meaning in entrepreneurship education. Education + Training , 48(5), 296-308.

Hodzic, S. (2016). Increasing PhD students' employability by focusing on the academic entrepreneurship. The analysis of the entrepreneurial competences. Tuning Journal for Higher Education, 3(2), 347-387.

Hoffman, J. (2004). Generalized Linear Models. Boston: Pearson Education Inc. Hofstede, G. (2001). Culture's Consequences: Comparing Values, Behaviors, Institutions, and Organizations Across Nations. Thousand Oaks, CA: Sage Publications.

House, R.J., Hanges, P.J., Javidan, M, Dorfman, P.W., \& Gupta, V. (2004). Culture, Leadership and Organizations: The GLOBE Study of 62 Societies. Thousand Oaks, CA: Sage Publications.

Itim International (2017, March 25). Geert Hofstede. National culture. Retrieved on from https://geert-hofstede.com/national-culture.html

Karatas-Ozkan, M. (2011). Understanding relational qualities of entrepreneurial learning: towards a multi-layered approach. Entrepreneurship and Regional Development, 23, 877-906.

Katz, J.A. (2008). Fully mature but not fully legitimate: A different perspective on the state of entrepreneurship education. Journal of Small Business Management \& Marketing, 46(4), 550-566.

Kluckhohn, F., \& Strodbeck, F. (1961). Variations in Value Orientations. Evanston, IL: Row, Peterson.

Landström, H., Harirchi, G., \& Åström, F. (2012). Entrepreneurship: Exploring the knowledge base. Research Policy, 41(7), 1154-1181.

Lans, T., Verstegen, J., \& Mulder, M. (2011). Analysing, pursuing and networking: Towards a validated three-factor framework for entrepreneurial competence from a small firm perspective. International Small Business Journal, 29(6), 695-713.

Le Deist, F. D., \& Winterton, J. (2005). What is competence? Human Resource Development International, 8(1), 27-46. 
Leon, R. D. (2014). University's contribution to the development of the future knowledge workers. In F. Uslu (Ed.), Proceedings of INTCESS14International Conference on Education and Social Sciences (pp. 313-322). Istanbul: OCERINT.

Leon, R.D. (2015). The future knowledge worker: An intercultural perspective. Management Dynamics in the Knowledge Economy, 3(4), 675-691.

Leon, R.D. (2016). The development of the future european knowledge workers. An academic perspective. Management Dynamics in the Knowledge Economy, 4(3), 339-356.

Man, T.W.Y. (2012). Developing a behaviour-centred model of entrepreneurial learning. Journal of Small Business and Enterprise Development, 19(3), 549-566.

Mitchelmore, S., \& Rowley, J. (2010). Entrepreneurial competencies: A literature review and development agenda. International Journal of Entrepreneurial Behavior \& Research, 16(2), 92-111.

Moberg, K. (2014). Two approaches to entrepreneurship education: The different effects of education for and through entrepreneurship at the lower secondary level. The International Journal of Management Education, 12(3), 512-528.

Moberg, K., Vestergaard, L., Fayolle, A., Redford, D., Cooney, T., Singer, S., . . Filip, D. (2014). How to Assess and Evaluate the Influence of Entrepreneurship Education: A Report of the ASTEE Project with a User Guide to the Tools. Copenhagen: The Danish Foundation for Entrepreneurship - Young Enterprise.

Moksony, F., \& Hegedus, R. (2014). The use of Poisson regression in the sociological study of suicide. Corvinus Journal of Sociology and Social Policy, 5(2), 97-114.

Morris, M.H., Webb, J.W., Fu, J., \& Singhal, S. (2013). A competency-based perspective on entrepreneurship education: Conceptual and empirical insights. Journal of Small Business Management, 51(3), 352-369.

Pittaway, L., \& Edwards, C. (2012). Assessment: Examining practice in entrepreneurship education. Education + Training, 54(8/9), 778-800.

Rae, D., \& Carswell, M. (2000). Using a life-story approach in researching entrepreneurial learning: the development of a conceptual model and its design of learning experiences. Education + Training, 42(4/5), 220-227.

Schelfhout, W., Bruggeman, K., \& de Maeyer, S. (2016). Evaluation of entrepreneurial competence through scaled behavioural indicators: Validation of an instrument. Studies in Educational Evaluation, 51, 29-41.

Schelfhout, W., Dochy, F., \& Janssens, S. (2004). The use of self, peer and teacher assessment as a feedback system in a learning environment aimed at fostering skills of cooperation in an entrepreneurial context. Assessment \& Evaluation in Higher Education, 29(2), 177-201.

Schenkel, M.T., Matthews, C.H., \& Ford, M. W. (2009). Making rational use of 'irrationality'? Exploring the role of need for cognitive closure in nascent 
entrepreneurial activity. Entrepreneurship \& Regional Development, 21(1), 51-76.

Seuneke, P., Lans, T., \& Wiskerke, J.S.C. (2013). Moving beyond entrepreneurial skills: Key factors driving entrepreneurial learning in multifunctional agriculture. Journal of Rural Studies, 32, 208-219.

Taatila, V., \& Down, S. (2012). Measuring entrepreneurial orientation of university students. Education Training, 54(8/9), 744-760.

Tabachnick, B.G., Fidell, L.S., \& Osterlind, S.J. (2001). Using Multivariate Statistics. Boston: Allyn and Bacon.

Tiwari, A. (2011). Nurturing entrepreneurship competencies through education: Reflection from entrepreneurs \& teacher's. Asia Pacific Journal of Research in Business Management, 2(10), 136-145.

Triandis, H.C. (1995). Individualism and Collectivism. Boulder: Westview.

Trompenaars, F. (1993). Riding the Waves of Culture: Understanding Cultural Diversity in Business. London: Economics Books.

Zahra, S.A., Sapienza, H.J., \& Davidsson, P. (2006). Entrepreneurship and dynamic capabilities: a review, model and research agenda. Journal of Management Studies, 43(4), 917-955.

\section{Abstract (in Polish)}

Celem badań jest ustalenie, $w$ jaki sposób uczelnie ekonomiczne $i$ biznesowe państw członkowskich Unii Europejskiej przyczyniajq się do rozwoju umiejętności przedsiębiorczych studentów. Dlatego stosuje się strategię studiów przypadku, która koncentruje się na najważniejszych szkołach biznesu z państw członkowskich Unii Europejskiej; w ten sposób zidentyfikowano i przeanalizowano 267 syllabusów z 21 uczelni wyższych. Wyniki pokazujq, że europejskie szkoły biznesu zdołały rozwinq̨́ większość wymaganych umiejętności w zakresie przedsiębiorczości wśród swoich studentów. Ich absolwenci sq zorientowani zarówno na zadania, jak i na ludzi. Z jednej strony ceniq sobie wydajność, sq $w$ stanie rozwiqzywać problemy i podejmować skalkulowane ryzyko. Z drugiej strony wiedzq, jak komunikować się i współpracować w ramach zespołu. Ponadto można stwierdzić, że analizowane programy edukacyjne łaczq podejście "o przedsiębiorczości” z perspektywq „dla przedsiębiorczości”; koncentrujq się na rozwijaniu kompetencji poznawczych, funkcjonalnych i behawioralnych poprzez łq̨czenie wykładów z aktywnymi technikami uczenia się. Działania te zależq od specyfiki kulturowej i majq wpływ na zdolność danego kraju do osiqgnięcia najwyższej skuteczności w zakresie rozwoju przedsiębiorczości. Odkrycia te maja zarówno teoretyczne, jak i praktyczne implikacje. Na poziomie teoretycznym poszerzajq literature dotyczqca rozwoju umiejętności przedsiębiorczych, dostarczajqc konkretnych informacji o umiejętnościach, na których koncentrujq się programy akademickie. Na poziomie praktycznym zapewniajq one cenny wglqad w umiejętności, które będq mieli przyszli przedsiębiorcy; wpłynie to na ich zachowanie w środowisku biznesowym, niezależnie od tego, czy zdecydujq się oni być właścicielami firmy, czy przedsiębiorczym pracownikiem. Słowa kluczowe: przedsiębiorczość, podejmowanie ryzyka, komunikacja, Uniwersytet, Unia Europejska. 


\section{Biographical note}

Ramona - Diana Leon is a Lecturer in Management Simulations and Knowledge Management at the National University of Political and Public Administration. She received her PhD in Management from the "Alexandru loan Cuza" University of lasi. She has worked in several projects about knowledge management, strategic management, and quality management in various sectors of activity such as education, textile and consulting services. Her main teaching and research interests lie in the areas of knowledge management and strategic management, with a special focus on intellectual capital valuation and strategic implications. In the last five years, Ramona has published several books, book chapters and articles in the field of knowledge management, strategic management, quality management, intellectual capital and emotional intelligence. In addition, she serves on the editorial boards of numerous international and national journals and conferences and is a full member of the International Association for Knowledge Management. She also has wide experience in Europe, collaborating with academics and managers from Romania and Spain. 

List of Reviewers Cooperating with the JEMI in 2017/2018

Aas, Tor Helge - University of Agder, Norway

Adamus, Wiktor - Jagiellonian University, Poland

Alekseevna, Babenko Vitalina - V.N. Karazin Kharkiv National University, Ukraine Bogacz-Wojtanowska, Ewa - Jagiellonian University, Poland

Bolisani, Ettore - University of Padova, Italy

Bratianu, Constantin - Bucharest University of Economic Studies, Romania

Breunig, Karl Joachim - Oslo Business School and Akershus University College, Norway

Buzoianu, Corina - National University of Political Studies and Public Administration, Romania

Calo, Francesca - Glasgow Calledonian University, UK

Carlan, Alexandru - National University of Political Studies and Public Administration, Romania

Cegarra, Juan Gabriel - Polytechnic University of Cartagena, Spain

Chang, Yu-Yu - Southern Taiwan University of Science and Technology, Taiwan Ciszewska-Mlinarič, Mariola - Kozminski University, Poland

Conde Bonfil, Carola - Universidad Autónoma Metropolitana Xochimilco, Mexico Csepregi, Anikó - University of Pannonia, Hungary

Dileo, Ivano - University of Bari, Italy

Durst, Sussane - University of Skövde, Sweden

Dymitrowski, Adam - Poznan Univeristy of Economics and Business, Poland Freiling, Jörg - University of Bremen, Germany

Fryczyńska, Marzena - Warsaw School of Economic, Poland

Gabryś, Bartłomiej J. - University of Economic in Katowice, Poland

Gancarczyk, Marta - Jagiellonian University in Kraków, Poland

Garmann-Johnsen, Niels Fredrik - Agder Research, Norway

Gaweł, Aleksandra - Poznan Univeristy of Economics and Business, Poland

Gębarowski, Marcin - Cracow University of Economic, Poland

Glinka, Beata - University of Warsaw, Poland

Głuc, Krzysztof - Cracow University of Economic, Poland

González-López, Manuel - University of Santiago de Compostela, Spain

Gudkova, Svetlana - Kozminski University, Poland

Günzel-Jensen, Franziska - Aarhus University, Denmark

Haim V. Levy - NanoDerma Ltd., Israel

Hauke-Lopes, Aleksandra - Poznan Univeristy of Economics and Business, Poland Hjemdahl, Kirsti M. - Agder Research, Norway

Hydle, Katja Maria - International Research Institute of Stavanger, Norway Inkinen, Henri - Lappeenranta University of Technology, Finland Jabłoński, Marek - WSB University Poznań, Faculty Chorzów, Poland 
Jasieński, Michał - Wyższa Szkoła Biznesu - National Louis University, Poland Jiménez Jiménez, Daniel - University of Murcia, Spain

Kawak, Wioletta - Wyższa Szkoła Biznesu - National Louis University, Poland Khoreva, Violetta - Hanken School of Economics, Finland Kianto, Aino - Lappeenranta University of Technology, Finland

Kisiel, Michał - Wrocław University of Economics, Poland

Koporcic, Nikolina - School of Business and Economics (ÅAU, Åbo Akademi University) \& Turku School of Economics, Finland

Lehner, Othmar - Oxford University, UK

Leśniak-Łebkowska, Grażyna - Warsaw School of Economic, Poland

Lewandowski, Mateusz - Jagiellonian University, Poland

Liang, Chaoyun - National Taiwan University, Taiwan

Lis, Andrzej - Nicolaus Copernicus University in Toruń, Poland

Lis, Anna - Gdansk University of Technology

Lisowska, Renata - University of Lodz, Poland

Magyar, Mária - Budapest University of Technology and Economics, Hungary Makieła, Zbigniew - Jagiellonian University in Kraków, Poland Mandjak, Tibor - Ecole Management Normandie, France

Massaro, Maurizio - University of Udine, Italy

Mielcarek, Paweł - Poznan Univeristy of Economics and Business, Poland

Mogiła, Zbigniew - Wroclaw Regional Development Agency, Poland

Morales-Alonso, Gustavo - Technical University of Madrid, Spain

Najda-Janoszka, Marta - Jagiellonian University in Kraków, Poland

Orłowski, Aleksander - Gdansk University of Technology, Poland

Oyugi, Jacob L. - Kyambogo University, Kampala, Uganda

Paliwoda-Matiolańska, Adrianna - Cracow University of Economics, Poland

Patena, Wiktor - Higher Colleges of Technology, United Arab Emirates

Pauli, Urban - Cracow University of Economics, Poland

Pawłowska, Anna - University of Warsaw, Poland

Petraite, Monika - Kaunas University of Technology, Lithuania

Pezzillo lacono, Mario - University of Campania Luigi Vanvitelli, Italy

Pimenova, Olena - Taras Shevchenko National University of Kyiv, Ukraine

Poledrini, Simone - University of Perugia, Italy

Poplavska, Zhanna - Polytechnic National University, Ukraine

Potoczek, Natalia - Wyżzza Szkoła Biznesu - National Louis University, Poland

Puślecki, Łukasz - Poznan Univeristy of Economics and Business, Poland

Scarso, Enrico - University of Padova, Italy

Schiau, Ioana - National University of Political Studies and Public Administration, Romania

Shil, Nikhil Chandra - East West University, Bangladesh 
Skjølsvik, Tale - Oslo and Akershus University College of Applied Sciences, Norway

Sławecki, Bartosz - Poznań University of Economics, Poland

Śliwa, Kazimierz - Andrzej Frycz Modrzewski Kraków University, Poland

Sokołowska-Woźniak, Justyna - Wyższa Szkoła Biznesu - National Louis University, Poland

Soniewicki, Marcin - Poznan Univeristy of Economics and Business, Poland

Sosnowska, Honorata - Warsaw School of Economic, Poland

Stankiewicz, Katarzyna - Gdansk University of Technology, Poland

Stefańska, Magdalena - Poznan Univeristy of Economics and Business, Poland

Stępień, Beata - Poznan Univeristy of Economics and Business, Poland

Szalkai, Zsuzsanna - Budapest University of Technology and Economics, Hungary

Szczerbicki, Edward - The University of Newcastle, Australia

Timmermans, Bram -Norwegian School of Economics, Norway

Trojak, Mariusz - Jagiellonian University, Poland

Uberman, Robert - Andrzej Frycz Modrzewski, Cracow University, Poland

Ujwary-Gil, Anna - Wyższa Szkoła Biznesu - National Louis University, Poland

Varmus, Michal - University Of Žilina, Slovakia

Vătămănescu, Elena-Mădălina - National University of Political Studies and

Public Administration Romania

Wach, Krzysztof - Cracow University of Economics, Poland

Wąsowska, Aleksandra - University of Warsaw, Poland

Zachorowska-Mazurkiewicz, Anna - Jagiellonian University, Poland

Zięba, Krzysztof - Gdansk University of Technology, Poland

Ziemiański, Paweł - Gdańsk University of Technology, Poland

Żur, Agnieszka - Cracow University of Economics, Poland 
